\title{
WestVirginiaUniversity
}

THE RESEARCH REPOSITORY @ WVU

Graduate Theses, Dissertations, and Problem Reports

2012

\section{The Word and the World: The Activist Spirit in American Literature, 1968-1998}

Jason M. Stupp

West Virginia University

Follow this and additional works at: https://researchrepository.wvu.edu/etd

\section{Recommended Citation}

Stupp, Jason M., "The Word and the World: The Activist Spirit in American Literature, 1968-1998" (2012). Graduate Theses, Dissertations, and Problem Reports. 3576.

https://researchrepository.wvu.edu/etd/3576

This Dissertation is protected by copyright and/or related rights. It has been brought to you by the The Research Repository @ WVU with permission from the rights-holder(s). You are free to use this Dissertation in any way that is permitted by the copyright and related rights legislation that applies to your use. For other uses you must obtain permission from the rights-holder(s) directly, unless additional rights are indicated by a Creative Commons license in the record and/ or on the work itself. This Dissertation has been accepted for inclusion in WVU Graduate Theses, Dissertations, and Problem Reports collection by an authorized administrator of The Research Repository @ WVU.

For more information, please contact researchrepository@mail.wvu.edu. 
The Word and the World: The Activist Spirit in American Literature, 1968-1998

\title{
Jason M. Stupp
}

Dissertation submitted to the Eberly College of Arts and Sciences at West Virginia University in partial fulfillment of the requirements for the degree of

\author{
Doctor of Philosophy \\ In \\ English
Kathleen Ryan, Ph.D, Chair
Gwen Bergner, Ph.D.
John Ernest, Ph.D.
Michael Germana, Ph.D.
Catherine John, Ph.D.
Department of English \\ Morgantown, West Virginia \\ 2012
}

Keywords: American Literature; 1960s; Activism; Social Praxis; Literary Theory;

Postmodernism

Copyright 2012 Jason M. Stupp 


\section{Abstract \\ The Word and the World: The Activist Spirit in American Literature, 1968-1998}

\section{Jason M. Stupp}

In The Word and the World: The Activist Spirit in American Literature, 1968-1998, I argue that some American authors confronted what Audre Lorde calls the "triumphs and errors" of the 1960s by producing literature that conceptualizes methodologies of resistance within sustainable models of community organization. Instead of succumbing to the inherent cynicism of the postmodern era, this literature encourages readers to adopt activist practices and to remain vigilant against oppressive government actions that intrude on civil liberties. Referring to selective works by Thomas Pynchon, Don DeLillo, Norman Mailer, Charles Johnson, Alice Walker, Toni Morrison, and Lorde, among others, I show how these authors - many of whom were shaped by their personal experiences of the sixties - reject naïve idealism while remaining hopeful of the possibility of progressive social change. Accordingly, they offer readers a chance to participate in the spirit of their work by fostering empathic connections with activist characters in worlds meant to serve as models for our own. By advancing a sense of cautious optimism in their work, the authors in this study reclaim the activist spirit of the 1960s while revealing to readers the many ways in which the social movements of the decade were flawed. Taken together, they also reclaim the need for resistance in a post-1960s period in which the gains of the civil rights and women's movements were met with conservative efforts to brand such resistance as anti-American and social activists as dangerous revolutionaries. The authors I discuss respond to such tactics by defining freedom as a practice, the conscious observance of which is in the service of progressive notions of social democratic governance and human rights. This practice extends to reading as well; as participatory texts, the works in this study command active reading that results in the critical questioning of standard, popular modes of discourse and academic theorizing. How one reads is therefore as important as what one reads, since to read radically is to imagine new ways of approaching the word and the world that account for the needs of marginalized, oppressed peoples as well as the communities we build and the values we promote. This particular group of "activist texts" thus redirects the indeterminate nature of value systems in mainstream postmodern literary and cultural theory to a project that remembers the potential of 1960s organizing - despite its shortcomings - to produce a better world for us all.

Drawing from work in literary theory, historiography, cultural studies, and performance studies, my methodology is grounded in an interdisciplinary project that mirrors the inclusive social paradigms of the texts I discuss. Like Marjorie Garber and Elizabeth Ammons, I am involved in literary analysis but incorporate ethical pronouncements that at times take the form of a manifesto for pragmatic literary scholarship. I argue that literary study is often too focused on aesthetic or stylistic value in text and should do more to uncover and promote the value of text in encouraging critical questioning and in shaping civic ideals and expectations. I conclude that locating examples of social praxis in American literature after the 1960s can benefit the efforts of contemporary movements such as Occupy Wall Street as they move forward in addressing the needs of marginalized peoples in the twenty-first century. Lastly, I argue that the relevance of such a project is reaffirmed by the recent turn in literary studies toward work relating to neoliberalism and global capitalism, which threaten to widen the disparities that reproduce inequality and make resistance necessary to human rights and social progress 


\section{Acknowledgments}

This dissertation would not have been possible without the guidance and support of a number of people. Katy Ryan, my director, was both energetic and wise in her role as the chair of my committee. I cannot thank her enough for her generous support, practical advice, and for keeping me on track and excited about my work. Her own work as a professor, scholar, and person has inspired me to no end. Gwen Bergner also served as one of the primary readers of this dissertation, and her untiring commitment to providing valuable feedback and encouragement has made the process of writing infinitely more enjoyable. When I needed it, she and Katy were also just good listeners and reminded me to think and write positively. Their example is one I aspire to as a teacher and human being. John Ernest not only offered sound comments on my work but also warned me not to lose my activist voice. The "soul" of my writing is influenced greatly by his work in African American studies, and his contributions to my outlook on life and literature extend far beyond the bounds of this project. Michael Germana's critical eye caught many instances in which I veered off-track or failed to consider an angle that inevitably improved my argument in significant ways. In addition to being a formidable reader, he also made me laugh often in his comments and conversation, which helped remind me that dissertations are supposed to be fun, too. When I needed a fifth reader, Catherine John of the University of Oklahoma agreed to serve on the committee of someone she'd never met. An admirer of her work, I am honored to include her in this list and hope to work with her more in the future. Additionally, I must thank all of my teachers at the undergraduate and graduate levels for nurturing me into a scholar, and I wish to express my deep gratitude to the Eberly College of Arts and Sciences as well as to the WVU English department for their support and for the dissertation fellowship that allowed me to complete this dissertation on time. I want to thank my family, especially my parents, who contributed a great deal to my education, and my mother-inlaw, Laurie, for providing a home and a space to write during my final year of writing. Most of all, I would not have been able to conceive of or write this dissertation without the love and support of my wife, Brittany, and my sons Coleton and Finnegan. They are my inspiration and push me not just to succeed, but to do so in a way that makes a positive impact on the world. If there is anything of value in this project, it is due in large part to these people, and any remaining errors in style or philosophy are mine alone. 


\section{Table of Contents}

Introduction:

Approaching the Word and the World: 1960s Activism and the Practical Use of Literature

Chapter One:

"A Real Dark Night of the Soul": The Armies of the Night and Postmodern Doom

Chapter Two:

Reclaiming Community and Resisting Cruelty in Thomas Pynchon's Vineland

Chapter Three:

Maternal Historiography and Cold War Citizenship in Don DeLillo's Libra

Chapter Four:

Buddhist Historiography: Mindfulness and Civil Rights in Charles Johnson's Dreamer

Chapter Five:

Linking Intelligence to Passion: Alice Walker's Meridian and Post-1960s Black Feminism

Conclusion:

Long Time Gone: Literature, Life, and Activism after the 1960s

Works Cited:

Curriculum Vitae: 


\section{Introduction:}

\section{Approaching the Word and the World: 1960s Activism and the Practical Use of Literature}

Now the trumpet summons us again —not as a call to bear arms, though arms we need; not as a call to battle, though embattled we are; but a call to bear the burden of a long twilight struggle, year in and year out, "rejoicing in hope, patient in tribulation," a struggle against the common enemies of man: tyranny, poverty, disease, and war itself.

— John F. Kennedy, Inaugural Address, January 20, 1961

In his book How Societies Remember (1989), Paul Connerton identifies two important modes through which we recall the past; the first is through "commemorative ceremonies," those instances when the cultural performance of the past is put on public display, and the second is through "bodily practices," or the changes in style, speech, and behavior that accompany supposedly distinctive periods of history. Drawing on the French Revolution as an example of these processes at work, Connerton argues that "if past injustice has shaped the structure of a society's present...the question arises as to what now, if anything, ought to be done to rectify these injustices" (9). Connerton focuses on the revolutionary period in France because of the ritualistic meaning inherent in the course of events - while regicide offered a seemingly definitive and literal break with the past and tradition, the adoption of a carnivalesque attitude toward dress was a strategic cultural move to rebuke the prescriptive authoritarian rule of the previous administration. In short, freedom of dress was a hallmark of the revolutionary period.

The crux of Connerton's argument in the book is that societies tend to repeat these patterns of behavior for each new period in which people seek to create distance from the recent past. This is especially true of revolutionary periods, which correspond with dramatic shifts in 
thought and behavior often as a response to oppressive governmental practices. In applying Connerton's observations to the American 1960s — which many consider to be the most revolutionary period in recent US history_-one is left with the stark realization that commemorative ceremonies and bodily practices often obscure the complexity of a decade in which revolution, televised for all to see, largely failed to upset the existing social order in the United States. The African American civil rights movement is inarguably the most compelling and celebrated instance of revolt in an era that also saw groups coming together to protest war and economic inequality, to work toward rights for women and people who identified as GLBT, and to seek recompense for the past and then-current injustices suffered by Native American Indians.

However, at the turn of the twenty-first century African Americans still saw higher mortality rates than white Americans and still struggled within the economic inequality that reproduces ghetto conditions, reduces the availability of jobs, health care, and affordable homes, and leads to incarceration rates for African Americans much higher than for white people. Additionally, GLBT groups, seeking to gain the right to marry for same-sex couples, were still being attacked by right-wing religious groups and were still denied basic civil rights available to heterosexual couples. Women still earned less money for performing the same jobs as men, and Native American Indian reservations continued to see untimely deaths as a result of alcoholism, malnutrition, and suicide. At the beginning of the new century, the US was also involved in two major armed conflicts in Iraq and Afghanistan and continued to occupy a large military presence on bases around the world. The question now becomes, "if past injustice has shaped the structure of a society's present," what practices are best able to prevent such injustice in the present and future? 
Part of my motivation for this dissertation comes from my belief that the way we remember the 1960s on a cultural level does a disservice to the revolutionary intent of those groups that fought for change. At the national level, we celebrate the life of Dr. Martin Luther King, Jr. with a national holiday, street signs, and monuments and — especially in public schools - focus on his message of integration while downplaying or completely ignoring his more radical stances against war and poverty. Malcolm $\mathrm{X}$ is remembered predominantly in popular memory as a radical Muslim, a designation that after the terrorist attacks of September 11, 2001 has a particularly negative connotation in American politics and social consciousness. Many celebrate the landmark legislation that made segregation and discrimination on the basis of race and gender illegal while considering that legislation to be, in many cases, "good enough" to counter the racism and sexism that still persist in the social landscape. Some might consider such an approach to the past to be a symptom of a hyperactive consumer culture; as Connerton notes in his follow-up How Modernity Forgets (2009), "in an age when permanent and unquestioned convictions lose their former sway, life's fleeting features gain more free play, and the break with the past focuses attention on the present" (60). It is easy to imagine how the idealism associated with 1960s activism could be lost in the ephemera of modern culture; not only do we exist from moment to moment, shuffling from one task to the next, much of our free time is spent seeking entertainment or, alternately, escape from the fast-paced environments in which we toil, week after week, year after year. With more and more Americans-adults and, increasingly, children—on prescription medication for depression or Attention Deficit Disorder, the premise of devoting oneself to social activism seems more and more illusory, the goals more out of reach. In many ways, however, the memories of the 1960 s we construct and use to build a national historical narrative are themselves illusory. To understand the revolutionary spirit of the 
decade, one must first fully grasp the complexity of social and political relations that dominated the period. This complexity precludes any sort of linear, causal history of the 1960 s and rests on the truth that, as with any other historical era, the sixties lends itself to multiple, sometimes competing interpretations. The premise of this study is that while many of these interpretations are valid, some can be considered to be of more historical and social importance than others. I intend to show how memorializing the 1960s in ways that divorce the social activism of the decade from contemporary relevance is both irresponsible and unethical; I uphold the notion of ethics — often discounted in a postmodern era that celebrated indeterminacy — as a necessary set of ideas and relationships that counter the tendency for power to become entrenched and to contribute to oppressive practices, particularly in relation to marginalized peoples and communities.

In The Word and the World: The Activist Spirit in American Literature, 1968-1998, I argue that American authors confronted what Audre Lorde calls the "triumphs and errors" of the 1960s by producing literature that conceptualizes methodologies of resistance within sustainable models of community organization. Instead of succumbing to the inherent cynicism of the postmodern era, this literature encourages readers to adopt activist practices and to remain vigilant against oppressive government actions that intrude on civil liberties. Referring to selective works by Thomas Pynchon, Don DeLillo, Norman Mailer, Charles Johnson, Alice Walker, Toni Morrison, and Lorde, among others, I show how these authors - many of whom were shaped by their personal experiences of the sixties — reject naïve idealism while remaining hopeful of the possibility of progressive social change. Accordingly, they offer readers a chance to participate in the spirit of their work by fostering empathic connections with activist characters in worlds meant to serve as models for our own. By advancing a sense of cautious optimism in 
their work, the authors in this study reclaim the activist spirit of the 1960s while revealing to readers the many ways in which the social movements of the decade were flawed. Taken together, they also reclaim the need for resistance in a post-1960s period in which the gains of the civil rights and women's movements were met with conservative efforts to brand such resistance as anti-American and social activists as dangerous revolutionaries. The authors I discuss respond to such tactics by defining freedom as a practice, the conscious observance of which is in the service of progressive notions of social democratic governance and human rights. This practice extends to reading as well; as participatory texts, the works in this study command active reading that results in the critical questioning of standard, popular modes of discourse and academic theorizing. How one reads is therefore as important as what one reads, since to read radically is to imagine new ways of approaching the word and the world that account for the needs of marginalized, oppressed peoples as well as the communities we build and the values we promote. This particular group of "activist texts" thus redirects the indeterminate nature of value systems in mainstream postmodern literary and cultural theory to a project that remembers the potential of 1960s organizing — despite its shortcomings - to produce a better world for us all.

\section{Whose 1960s?}

Any study of the 1960s must begin by acknowledging the complexity of the people, movements, and events that marked the decade as a distinct historical period. Periodization is always a problem in any study of the past; as Fredric Jameson writes in "Periodizing the 60s" (1984), the decade is best "understood not as some omnipresent and uniform shared style or way of thinking and acting, but rather as the sharing of a common objective situation, to which a whole range of varied responses and creative innovations is then possible, but always within that situation's structural limits" (178). In this case, it becomes necessary to first plot what we might 
call the beginning and end of the sixties by situating it within a recognizable series of defining moments - the "objective situation." The common consensus on a frame for the 1960 s seems to rest on the period from 1960-1975 - the beginning of the decade (and JFK's presidential campaign and victory) to the fall of Saigon and the "end" of the war in Vietnam. However, this frame does not fully account for other events, such as the civil rights movement (commonly referred to as beginning with the 1954 US Supreme Court decision to outlaw segregation and ending with Martin Luther King, Jr.'s murder in 1968), second-wave US feminism (roughly 1960-early 1980s), and other key events that inspired or drew from the period. Additionally, grassroots movements are anything but linear and organized - to fit them neatly within a timeline of events is both historically inaccurate and, in some ways, socially irresponsible. For instance, Jameson argues against pop-culture versions of the past but admits that a grand vision of a period simply does not exist: "nostalgic commemoration of the glories of the 60s or abject public confession of the decade's many failures and missed opportunities are two errors which cannot be avoided by some middle path that threads its way in between" (178). Looking backward depends upon the same type of objective situation as does present action, so the difficulty lies in finding a frame of reference that accounts for objectivity while at the same time emphasizing the ideas, people, and moments that provide useful material for analysis and discussion, keeping in mind that the motivation for and goals of these discussions vary greatly depending upon group interests and the intended audience.

The present study is an attempt at such a frame. Because of length and time restraints, I have largely omitted discussions of very significant groups and movements related to the 1960s, specifically the American Indian Movement, those who fought for gay rights, and international movements and perspectives that contributed to sixties activism. I have also omitted novels about 
the war in Vietnam, because I view many of these as different in intent and spirit from the novels I address. While I recognize that systems of oppression are interrelated - and so are, accordingly, networks of resistance to that oppression-I have chosen to focus on the most visible history of the 1960 s in order to comment on the "official history" and cultural memory of the era and the literary contribution and reaction to that history and memory. I thus limit myself to literature that responds to the civil rights movement, the counterculture, the antiwar movement, black feminism, and to pro-democracy, anticommunist Cold War rhetoric and posturing. By doing so, I hope to critique false notions of an idealistic, utopian era of social promise and, alternatively, the conservative view of the sixties which presents the counterculture as a haven for dope fiends and Black liberation movements as composed of violent, black supremacist revolutionary thugs. As Jameson suggests, there is no identifiable "middle road" between these extremes; the value of literary study is in the opportunities it allows for revealing and attempting to understand and learn from the complexity of history, memory, and narrative structure - knowledge that can turn historical transmission into an active, conscious practice of putting the past in relation to one's self, community, and world.

Such a project insists that one make important decisions related to authority, agency, purpose, and method. Whose history is more authentic or accurate? Which groups take precedence in popular memory, and is their significance inflated at the expense of others who go largely ignored in discussions of the decade? How does race figure into representations of American feminism? How did the antiwar movement — at some levels — exist along the same class lines that protestors often decried as unfairly sending men from poor communities to war? How was the idealism of the 1960s corrupted by infiltration by authority, betrayal, murder/assassination, commercialism, consumerism, and celebrity culture? Did the 1960s evolve 
the way we like to imagine it did, with a popular revolt based in love, peace, and equality taking center stage, or was it defined instead by a chaotic mass of shaky allegiances, competing interests, and gratuitously violent, authoritarian responses to resistance? Was America changed for the better, or did the gains of the 1960s translate into promises on paper that did little to affect the lives or opportunities of the people most in need of help? Lastly, why the 1960s? What is the importance of the decade in relation to current sociopolitical thought? What can it tell us about ourselves - about where we've been and where we're headed?

As the epigraph to this introduction suggests, these are not easy questions to answer, and no one answer will suffice. The US is still caught in what Kennedy called the "long twilight struggle": the fight for rights is far from over, and the reality of oppression lacks the same capacity to shock and impel people to action as it did in the sixties, when middle class folks at home first began to get a glimpse of violence in the streets and war at home and abroad. Malcolm X's practice of seeing America "though the eyes of the victim" has now become so commonplace as to reduce the victim to little more than an object worthy of sympathy or, in the case of racism, sexism, homophobia, and anti-immigration measures, an object of scorn that results in cliché and overwrought defenses of personal responsibility and American democratic freedom, or ludicrous accusations of "reverse" discrimination against those (white males) who have enjoyed centuries of privilege ("The Ballot or the Bullet," 1964). The answer to the question, "Why the 1960s? Why now?" is that while the issues brought to the surface of American consciousness in the sixties were and continue to be addressed and debated, there has yet to be realized the kind of progress that meaningfully benefits people's lives in a transformative, lasting way. Attempts to discount the promise of sixties-style activism hide the truth that those in power do not wish to relinquish that power, especially not to those who would 
upset the traditional methods through which wealth, resources, and influence flow to fewer and fewer of the privileged elite. As the Occupy Wall Street movement has revealed since its appearance in 2011, public mass protest and organized resistance to authority continue to draw violent responses from the state and ridicule from the conservative media. In other ways, it has shown how we have learned from the sixties; OWS protests strive to be multiethnic, cooperational events that aim to build and solidify resistance to economic inequality and the coalition of money and politics that govern the United States (in addition to its international influence), a mission which recognizes and capitalizes on the interrelated nature of various forms of marginalization.

The period I limit myself to in this study - 1968-1998 — captures the activist spirit in American literature from the period in which "postmodernism" was beginning to enter the mainstream until around the time that literary and cultural studies began to really take notice of the ways in which neoliberalism and transnational, global policies and patterns shape the postpostmodern, post-multicultural, post-feminist era. The prefix "post" can be misleading for a number of reasons, but chiefly because it signifies a shift not necessarily of practical use but of theoretical interest. At the time of this writing, contemporary mass social movements such as the "Arab Spring" and OWS are rooted firmly in issues of patriarchy, race, and class; however, they are also a product of a neoliberal, global, social-media driven age. The American 1960s remain relevant primarily because they largely failed to achieve what these more modern movements seem to have successfully begun: an international crusade against the interrelated sources of oppression-religious tyranny, entrenched power, socioeconomic privilege, ethnic, racial, and cultural discrimination - that in the sixties were attacked more through their symptoms than at the source. As the 1960s revealed, however, idealism can quickly turn into cynicism; the 
importance of looking back now is in determining how and why sustained activism is so difficult and in learning how to best proceed. In order for social progress to occur, there must first be a social agreement to adhere to a set of ethics that drive that progress; Karl Marlantes perhaps put it best in his book What It Is Like to Go to War (2011), in which he distinguishes between moral ideas as representing an ideal state of behavior and moral standards, which correspond to actual, lived patterns of behavior (113). Writing about the war in Vietnam, Marlantes claims that many of the atrocities committed during the war were the result of "fallen standards," a situation in which morally-questionable behavior becomes normalized (113). For contemporary social movements to succeed, they need to first agree on standards and then live by them, a process that can be enlightened by looking at the example of the sixties, during which ideals could often not be lived up to, and standards were overcome through betrayal and government infiltration and violence.

Protest, by definition, is grounded in ethical claims determined to expose and correct injustice. During the American 1960s, the ethical consciousness of the public was confronted with images of police brutality against peaceful demonstrators, black communities crippled by poverty and racist discrimination and violence, napalmed Vietnamese children and entire villages burnt to the ground, and American GIs returning from Southeast Asia with missing limbs and haunting memories of death (if they were lucky) and in coffins (if they weren't). My intention in this study is to promote the use of literary critical pragmatism (that is, a methodology that combines theory with action) to underline the ways in which literature can imaginatively connect with readers to raise ethical consciousness and inspire action. In doing so, I hold up a view of the sixties that recovers the optimism and necessity of activist movements while addressing those instances in which activism failed to account for the verities of the human condition, such as the 
incredible staying power and adaptability of authority in maintaining social order and the tendency for selfishness to overrule judgment and loyalty. I suggest a way of reading that seeks connections with others and looks for models of thought and community organizing that can be applied to the real world. I attempt to steer clear of judgments about the purpose of text, but make clear that I find writing that evinces a social or political agenda to be formative examples of how literary worlds can help us understand and improve our own.

Surely, there are those who are not convinced that value-based assessments of literature are warranted or even appropriate territory for a literary critic. Richard Posner, writing against ethical criticism, concludes that "immersion in literature does not make us better citizens or better people... [and] authors' moral qualities or opinions should not affect our valuations of their works" (64). In fact, Posner refers to the "moral properties" of an author or a text as "almost sheer distraction" (76). Instead, he favors an aesthetic tradition that underscores the ways in which literature can provide psychological benefits by helping us to better understand ourselves and our places in the world. One wonders, however, how Posner would classify religious texts; do millions read the Koran or the Christian Bible for psychology, or for guidance on how to approach the world? Furthermore, why should this activity be strictly limited to religious texts? Can one not grow as an individual, become more sensitive to others, be more accepting of other people and cultures from reading fiction? Is there not an ethical or moral element to such acts of conscious reading? Wayne Booth responds to assertions such as Posner's by claiming that "no one who has thought about it for long can deny that we are least partly constructed, in our most fundamental moral character, by the stories we have heard...the stories we have really listened to" (26). What Booth calls "responsible readers" are those who can isolate, evaluate, and act on those moments in a story which call for some kind of ethical judgment, even if that action 
corresponds simply to a decision to, for example, try harder to understand the anti-American sentiment of some people in the Middle East (24). Charles Johnson writes about his novel Dreamer (a fictional account of Dr. Martin Luther King, and the subject of chapter four), "moral fiction presents a 'we-relation' - a social world of people and perspectives...which mirrors and clarifies our own daily lives" (260). This "we-relation" does not exist solely in the present; once established, it also connects us to our ancestors, to those in the recent past, and to those (like King in Johnson's novel) whose example we wish not to forget.

To walk the line between ethics and aesthetics in literary criticism is dangerous ground, but it is ground that could save the humanities from charges that it is becoming obsolete in an increasingly competitive, market-driven, globalized world. As Elizabeth Ammons rightly points out in Brave New Words: How Literature Will Save the Planet (2011), "human beings, for good reason, seek answers. Yet for more than twenty-five years the most highly valued academic approach in the humanities has frequently amounted to little more than endless questioning, a process of dismantling certitude upon certitude until all that remains is...instability. Nothing to hang on to, nowhere to stand" (2-3). This "postmodern fundamentalism," as Ammons calls it, comes ironically out of the sixties and from attempts to disperse knowledge and authority along non-hegemonic lines of inquiry. The result, however, is that the humanities—-to many-no longer offers any practical value. The point is not that a category of criticism like "ethical theory" or "moral inquiry" become master narratives themselves, but that they are considered a legitimate and even necessary option for literary critics to apply when, where, and how they see fit. Despite the appeal of some moral philosophers' theories of literature- such as that of Richard Rorty, whose views on pragmatism battle the apparent contingency of the postmodern era - they too sometimes reveal an attempt at dominance. David Parker explains how, for 
instance, Rorty speaks of a " final vocabulary" in Contingency, Irony, and Solidarity (1989) that "seemed often to demand that we see all alternative views as forms of false consciousness" (5). Granted, there will always be a need for the sort of literary-historical work that has become the focus of cultural studies and for work that explores the interdisciplinary nature of the humanities in seemingly more objective, empirical ways. However, observation and experience often lead us back to the big questions at the center of our existence and ask us to pull apart the threads and connections that such work draws together.

In the present study, I put forth an ethical mode of criticism not to undermine other forms of literary study, but to suggest that there exists in American literature of the post-1960s period a conscious ethical positioning within and against the sixties that is worthy of note, and that the practical implications of this literature to social, philosophical, and historical thought could have significant cultural impact, particularly for those movements such as OWS that at times capture the spirit of what sixties' activism was intended to be. This spirit is present in the work I discuss, and consciously so; it is meant to align readers with those who struggled to live in defense of freedom in an era of mass protest. Literary critics are "responsible readers" when they work with the text to tease out motives, question thought and action, and look for what is useful in the text, the "something" that makes it worthy of study. Like Marjorie Garber in A Manifesto for Literary Studies (2003), I claim "an unapologetic freestanding power to change the world by reading" (12-13). My project is rooted in literary and historical analysis, but at times takes the form of a manifesto, like Garber's book, "in the sense that it invites strong declarations and big ideas, rather than impeccable small contributions to edifices long under construction" (13). In doing so, I hope not to lecture or moralize but to encourage and inspire; if the "Arab Spring" and OWS movements reveal anything about the early twenty-first century, it is that there is a global feeling 
of restlessness and anger concerning the trajectory of world economics and politics. I, for one, support such feelings because of their focus on the common good, on freedom as a practice of opposing all forms of cruelty and marginalization, and on providing opportunities for those currently without them. As a scholar of literature, I hope to support their cause by pointing to what I know best-literature - and to the ways in which we can use literature to learn from one of the most revolutionary moments in modern US history.

\section{The Word: Radical Reading and Postmodern Pragmatism}

In speaking about the methodology for this project, I must first discuss the "objective situation" of postmodern literary theory, since many consider the timeframe of my study to incorporate the postmodern era in American literature. Just as postmodernism is a reflection of the epistemological pluralism that led to the creation of categories such as "multicultural studies" in the academy, that which we call "postmodern" is itself pluralistic — no one theory or critical stance can be said to encompass the entirety of postmodern thinking. Still, it seems plausible to construct an objective view of postmodern critical positioning that accounts for the majority of the mainstream philosophical, political, and ethical groundings associated with postmodern literary study, or what Ammons refers to as "postmodern fundamentalism." The period referred to as postmodernism is characteristically identified with notions of contingency, heterogeneity, globalism, revisionism of all kinds, relativism, indeterminacy, multiplicity, and synthetic or manufactured reality — what Zygmunt Bauman refers to as "liquid modernity," or the transition from solid social forms to a period of inherent and unstable flux (1). Whether one think of postmodernism as, to quote Jameson, a "cultural dominant" instead of a style, or as JeanFrancois Lyotard suggests, a misnomer "for the single reason that it leaves unquestioned the position of the 'now', of the present from which one is supposed to be able to achieve a 
legitimate perspective," the message remains the same: postmodernity signals a period of fluctuation and instability $(4,24)$. Well-known examples of postmodern literary theory, such as Brian McHale's Postmodernist Fiction (1987), trace the emergence of the postmodern in literature that is concerned more with ontological issues than with epistemology. However, as I make clear in chapter five concerning Alice Walker's Meridian (1976) and post-1960s African American feminism, the postmodern period for many women writers of color signaled a time in which the epistemologies of race and patriarchy were still very much active and in need of dismantling. Joy James discusses the distrust toward mainstream literary postmodern felt by many black scholars: "postmodernism's postrevolutionary rhetoric fails to address the specificity of antiblack racism and oppression...it tended to express greater concern for black people as texts rather than as black people whose lives were in struggle" (175). Accordingly, what is meant by "postmodernism" varies wildly depending upon the intellectual tradition in which it is employed; while this may seem old news in many critical circles, it bears repeating because of the turn toward post-postmodernism that began to take form in the twenty-first century, and which at times fails to critique what James calls the "postrevolutionary" rhetoric of postmodernism.

To put it another way, the move "beyond" postmodernism threatens to once again marginalize the "others" who are supposedly no longer "other." In her article "The Ends of America, the Ends of Postmodernism" (2007), Rachel Adams discusses the "globalization of American literature" and how her American literature students can no longer relate to canonical postmodern texts such as Thomas Pynchon's The Crying of Lot 49 (1966), which leads her to conclude that the terms "postmodern" and "contemporary" can no longer coexist with a new generation of readers (249). Adams frames literary postmodernism as a response to the 
"containment culture" of Cold-War politics and rhetoric (the subject of chapter three in this study) and claims that her "historically and stylistically bounded" understanding of postmodernism — which includes a long list of white authors, Ishmael Reed, and a single woman in Kathy Acker — saw its demise at the end of the 1980s (250). "American literary globalism," on the other hand, includes marginalized authors of all ethnicities and nationalities who embody a reaction to "high postmodernism" and who ushered in a "new chapter" in American literary history. Adams's argument is similar in nature to that of Jeffrey Nealon, who in PostPostmodernism; Or, the Cultural Logic of Just-In-Time Capitalism (2012), refers to Jameson's now-canonical 1984 definition of postmodernism as the "cultural logic of late capitalism" to declare that the post-postmodern period is not so much a transition as an "intensification" of the fragmentation characteristic of the postmodern age. While Adams's terrain is literature and Nealon's is global systems of capital, both suggest that intensified fragmentation and heterogeneity are the hallmark of the post-postmodern world. While both of their arguments make a good deal of sense, they periodize postmodernism as a reaction of either a generation of Cold-War inspired authors or of global economic trends. What is the danger, though, in asserting a new era when the issues of the previous one have not yet been resolved?

This question is in no way meant to discount the work of Adams or Nealon; both offer solid evidence as to how historical, economic, and cultural shifts require us to conceive of new ways to confront contemporary issues. In addition, their ideas correspond with the shift in literary and cultural criticism toward transnationalism, globalism, and neoliberalism, to which books like Michael Hardt and Antonio Negri’s Empire (2000), Inderpal Grewal's Transnational America: Feminisms, Diasporas, and Neoliberalisms (2005), David Harvey’s Spaces of Global Capitalism: Towards a Theory of Uneven Geographical Development (2006), and Wai Chee 
Dimock's Through Other Continents: American Literature Across Deep Time (2008) can attest. At the center of my own thinking about postmodernism is the nagging thought that if we define postmodernism another way - that is, as a postrevolutionary period in which the experiences of the so-called revolution(s) of the 1960s were just beginning to make a degree of sense- then the political project of the period, particularly for those marginalized by their race, ethnicity, gender, or sexual orientation, was to understand where the social movements of the 1960 s failed and to reorient the struggle to position oneself within and against the sixties in a new era of resistance. While the work of scholars such as Adams and Neale provides answers to what, in fact, the struggle is against, it does little to answer the question of how such resistance can be accomplished. My own framing of literary postmodernism in this project consists of texts that celebrate the political opportunities of pluralism while re-inscribing the value of ethics in literary study and in life. These texts view the post-1960s landscape with what I call "cautious optimism," a stance that privileges a participatory, pragmatic approach to text that encourages an active relationship to the world and to causes that offer critical assistance to those who suffer under the political and economic policies that accompanied "late capitalism."

The "postmodern" authors I discuss I define as postmodern because they contribute to the political project of situating the postmodern period within a context of sixties-influenced social praxis. Works such as Norman Mailer's The Armies of the Night (1968), Thomas Pynchon's Vineland (1990), Don DeLillo's Libra (1988), Charles Johnson's Dreamer (1998), Alice Walker's Meridian (1976), and the post-1960s writings of a specific group of black feminists (including Walker, Toni Morrison, Barbara Smith, bell hooks, and Audre Lorde) respond to what Kathryn Hume terms the "slough of despond" characterizing some American literature of the post-1960s era, in which American authors increasingly expressed a "bitter disillusionment with 
America and the American Dream" (1). Hume's "slough of despond" is a symptom of cultural decline, a recognition that the myth of American democracy has once again been exposed; it has its root in what Jean Baudrillard terms the "void" at the center of what we call postmodernism:

[Postmodernism] is an expression, a word which people use but which explains nothing. It's not even a concept. It's nothing at all. It's because it's impossible to define what's going on now, grand theories are over and done with, as Lyotard says. That is, there is a sort of void, a vacuum. It's because there is nothing really to express this that an empty term has been chosen to designate what is really empty (22).

Baudrillard's rejection of postmodern periodization and terminology has to do with this void; how, in other words, can one conceptualize a void in a way that makes sense, in a way that does not, in effect, revert to a sort of Nietzschean cynicism? He insists that postmodernity is constructed as a response to the void, but that its suggestive linearity turns it against itself in a "curvature" toward history instead of the future (22). For this reason, it becomes possible to see that postmodernity is part of the process described by Connerton: every society in a period of revolutionary change is postmodern, and it has been this way throughout history. The problem with the postmodern — as its supposed chief architects can attest — is that it does not exist as a recognizable social form, but as bricolage, as a collage of what's-left-over from the previous era and attempts to refashion what's left into a coherent discursive form (or, alternately, to celebrate its incoherence).

The authors in this study attempt to fashion the remainders of 1960s activist spirit into conceivable methodologies of resistance that use literary study to promote coalitions and practices related to social progress. They acknowledge that within pluralism is a definable center 
that correlates with the center within ourselves, a pull toward unity and wholeness that makes a disparate world connect on issues of human rights and civil organizing. Baudrillard's emptiness at the center of culture is also a bodily emptiness - an emptiness Norman Mailer covers at length in The Armies of the Night (1968, the subject of chapter one). There is a tendency to see the postmodern void as liberatory in many ways, principally because it offers freedom from the restraints of authoritative discourse and social custom. However, the anxiety produced by neoliberal, global economics and vast, impersonal networks of production has led to a movement toward stability and community by which people combat what Bauman terms the "matrix of random connections and disconnections" of a society that is "viewed and treated" as a "'network' rather than a 'structure"” (3).

Literary theory, as shown by Ammons, can follow along similar lines; scholarship that recovers "ethical" modes of reading from prescriptive, censorship-driven modes of ethical discourse that sought to control what one reads can reassert the potential of solidarity and community to counteract alienation, despair, and anxiety. Kathleen Lundeen argues that "though postmodern critique has not preempted representation acts, it has left many in a duplicitous relationship with culture...always keeping an eye out for the ways they are being had" (84). This relationship is debilitating, according to Michael Roth, who explains how such criticism creates confining spaces he terms the "ironist's cage," the "prison of the cultural critics who realize that they have no position from which to make their criticism" (8). According to Roth, the function of history writing, particularly after the nineteenth century, has been to establish group identity and to write or rewrite the recent past in order to create a "usable past," or a "past with which a group of people can live" (10). However, Roth observes how "in our time the criteria for establishing a particular history as legitimate have become extremely unstable" (10). One tactic is to create a 
"usable past" in the literal sense; the pragmatic approach to literature I emphasize in the following pages illustrates how American authors used the experience of the 1960s to make conscious moves toward activist principles that stand in relation to the past, present, and future. In this way, they not only create legitimate narratives of the past but also attempt to fashion "usable futures," visions of sustainability that promote a skeptical idealism with one foot planted firmly on the ground (or, perhaps, in the street, marching).

\section{Chapter One: "A Real Dark Night of the Soul": The Armies of the Night and Postmodern}

\section{Doom}

I start by looking at Norman Mailer's The Armies of the Night, his accounting of the events of the 1967 March on the Pentagon. Part history, part novel, Mailer's book is an egodriven yet responsible (in its refusal to idealize war or antiwar protests) depiction of the process of and response to resistance in a wartime US culture. I define Mailer's text as postmodern partly because of its "postmodern doom" in its representation of the uncertainty and anxiety of a 1960s in which America was no longer fighting fascism and genocide, but "international communism," a fight occurring at home and abroad with no clear enemy and no objective end in sight. While Mailer sides with antiwar demonstrators throughout, his characteristic cynicism is present as he faults 1960s activists (especially academics) for preferring rhetoric over action and, in the case of "hippies," drugs and theatricality over judgment and discipline.

Still, Armies is an activist text. In it, Mailer takes stock of the 1960s, of America's decline into what he thinks is totalitarianism, of the "coded language" of power that restricts access to power, and of the spiritual sickness at the heart of America that manifests in using advanced weapons technology to decimate villages in Southeast Asia instead of in critical selfreflection and social progress at home. Mailer uses Armies to ask what responsibility authors 
have to both document this sickness and to imagine remedies for it; ultimately, he rejects objective histories because of their failure to produce deep knowledge of the people, events, and the intangible qualities of lived experience. Accordingly, Armies positions the novel (and, in this case, the historical novel) as an imaginative connection between people and the recent past and the figures who come alive within its pages. Theoretically, I situate Armies in terms of the poststructural cultural criticism of Michel Foucault (who Roth argues is in the ironist's cage) and the postmodern historiography of Roth. I argue that Roth's work on irony overlooks how Foucault and Mailer's pessimism has a distinct value in political thought and historical analysis. Despite his own cynical detachment at times, Mailer urges readers to become involved citizens and to resist the coming totalitarianism. As a 1960s text, Armies is a fitting start for my project because its call to action, I argue, was taken up by subsequent American authors of the post1960s period.

\section{Chapter Two: Reclaiming Community and Resisting Cruelty in Thomas Pynchon's}

\section{Vineland}

Next, I fast-forward to the 1980s and Thomas Pynchon's Vineland (1990), a novel that moves between the 1960s and 1984, to show how Mailer's vision of a totalitarian America was realized in the conservative turn in American politics (symbolically linked in the novel with Ronald Reagan's reelection) and in the war on drugs that imprisoned thousands, turned friends and family into "snitches," and threatened always to further erode civil liberties. Pynchon exemplifies an alternative to Mailer's pessimism that reserves hope for change in spite of the seeming futility of resistance to authority. By the time of Vineland's setting, the postmodern doom of Armies has been realized in the ubiquity of the Tube, a sort of religious faith in consumerism and capitalism, and in the transition from resistance to acceptance of the status quo. 
However, as in Pynchon's previous work, there is an underground in Vineland that continues to provide the "alternative America" that is a refuge for those who continue to fight for freedom. Just as Oedipa Maas traversed the postmodern California landscape of the early sixties in The Crying of Lot 49, Pynchon employs Prairie Wheeler, the fourteen-year-old daughter of activist parents, to navigate the terrain of Vineland. Prairie, who I argue can be viewed as the symbolic child imagined at the end of Armies — equal parts democratic promise and totalitarian threat — is a sort of medium in the novel connecting readers to the 1960 s as she searches for her missing mother, Frenesi, a radical-film-director-turned-government-snitch on the run from the villainous Brock Vond, a federal prosecutor representing the fascist capabilities of government authority. Vineland exemplifies Mailer's claim that the novel can serve to connect readers to a time and place while urging them to take a political stance in response to the events they "witness." Prairie's attempts to empathically experience her mother through archival video footage is both a critique of the virtual reality Pynchon finds in the Tube and a venue for political possibilities; by relating to the past, we can further understand our present and figure out where we're headed. While this premise is nothing new, Prairie's actions exemplify what Alison Landsberg has termed the creation of "prosthetic memory," or a "more personal, deeply felt memory of a past event through which [one] did not live [and that] has the ability to shape that person's subjectivity and politics" (2). Pynchon utilizes scenes in which Prairie connects with her mother to pull the reader into the past in the novel, a past in which idealism is shattered through government intervention and detention. In what could be called "The Education of Prairie Wheeler," readers are taken through the experience of an impressionable young person's transition into political awareness; in the process, Prairie's naïve and immature notions of civic responsibility and human nature are turned into a precarious stance against cruelty and 
government oppression (a stance Pynchon is careful to reveal as tenuous and always at risk). Vineland encourages such political awareness and the conscious practice of freedom in its readers; through the creation of inclusive communities of resistance, Pynchon suggests, we can bring a "cautious optimism" to our daily activities to foster sustainable alternatives to social and political practices that undermine civil rights and marginalize those who protest against authority.

\section{Chapter Three: Maternal Historiography and Cold War Citizenship in Don DeLillo's Libra}

Chapter three looks at Don DeLillo's Libra (1988), which offers readers an empathic connection to Lee Harvey Oswald and his mother, Marguerite, through a reconstruction of Lee's life up to his (in DeLillo's vision) complicity in a conspiratorial version of the events of JFK's assassination. I argue that DeLillo creates a "maternal historiography" in his retelling of the assassination that revises the popular view of Marguerite Oswald as a self-centered liar and manipulator and of Lee as a cold-blooded and deranged assassin. The novel drew harsh criticism from conservative writers such as George Will and Jonathan Yardely, and I show how this criticism is a symptom of the similar Cold War rhetoric and positioning that demonized the Oswalds.

I point to the work of Alan Nadel, Lauren Berlant, and Donald Pease in arguing that DeLillo constructs Marguerite as an activist character who critiques the "containment culture" of the Cold War period (and of which her son is seemingly the antithesis). I also describe how her character is involved in oral history performance that underlines a "radical mother" subjectivity and creates a space of resistance to totalizing narratives of femininity and motherhood. The domestic space of the home in Libra is political space; it is used to convict Marguerite of being a bad mother, is pierced by images of JFK and Lee Harvey Oswald's murders, and is reframed by 
DeLillo as a site of critical agency in discussions of how personal lives become entrenched in national narratives of belonging or, conversely, marginalization. Libra, published toward the end of the conservative US 1980s, offers a way of looking at history that urges readers to critique the containment narrative of conservatism and how it can obscure the very democratic process of civil organization. Lee Harvey Oswald, a so-called radical, is often held up as the deranged product of Soviet, communist ideology; in fact, suggests DeLillo, he is a product of the same economic disparity that creates outcasts in any generation, and his urge to kill is implicitly approved of by a government that sends its forces out to assassinate political enemies such as Fidel Castro. Like Pynchon, DeLillo asks readers to look to their own time-in this case, the Reagan years of Vineland - to determine in what ways they are being contained and how the lessons learned from 1960s culture can be put to use in forming "outcast subjectivities" that refuse to remain silent.

\section{Chapter Four: Buddhist Historiography: Mindfulness and Civil Rights in Charles Johnson's Dreamer}

Charles Johnson's fictional account of Martin Luther King, Jr.'s final years in Dreamer (1998), like DeLillo's account of the Oswalds, aims to emphasize a "new kind of knowledge" about King that, in addition to creating an empathic connection with the civil rights leader, encourages readers to remember King in an active instead of passive fashion. Johnson, often considered a postmodern author, counters postmodern cynicism and detachment through a narrative of spiritual awakening and renewal. He imagines a double for King named Chaym Smith who embodies what one could call a "postmodern" African American man: he identifies with no community, is spiritually bereft, and is concerned only with himself and rejects attachment to people or things. However, while working as a body double for King to protect 
him from harm, he is overcome by King's vision of the "beloved community" and is drawn back into connecting with others, especially other African Americans. Johnson's novel is a memorial to King - a living monument that asks to be treated as a participatory text and regarded as an invitation to continue the work King started during his life.

Throughout, I frame Dreamer as an example of what I call "Buddhist historiography." Like in my discussion of Libra, I argue that Johnson's text introduces an alternative way of reading and experiencing the recent past that lends itself to pragmatic interpretation; in other words, instead of a static historical text, Dreamer imaginatively situates readers within and against a series of events that could inspire them to action. When Matthew Bishop, the young SCLC intern and narrator of part of the novel, announces that "we all killed him" after King is shot, Johnson also points a finger at readers, seeming to say that we all continue to kill King by memorializing him in ways that are counterintuitive to his message. Drawing from postmodern theorists such as Linda Hutcheon and Satya Mohanty, as well as civil rights history and African American historiography, I claim that "Buddhist historiography" is Johnson's response to the 1960s and particularly to King's death; it proposes an engaged pluralism at the heart of which is one consciousness that, if positioned outside the limits of the ego, sees difference as a fundamental design of a universe in which everything is intimately connected. Ultimately, Dreamer asks readers what they will do with this knowledge. As a participatory text, it encourages readers to apply King's message to their daily interactions with the planet, their communities, and each other while recovering that message from the simplistic narratives of overcoming associated with King in popular culture and the militant violence of Black Power Johnson argues is now embraced by contemporary black youth. 


\section{Chapter Five: Linking Intelligence to Passion: Alice Walker's Meridian and Post-1960s Black Feminism}

The concluding chapter in this study presents an example of literary critical pragmatism from the post-1960s period. Alice Walker's Meridian (1976) is the story of a young woman, Meridian Hill, and her coming-of-age as a young civil rights activist working to register voters in the South. Throughout the novel, Meridian fights for the rights of small, rural black communities on a political level while staying detached from them on a personal level. She feels exiled as a result of her mother's condemnation of her for giving up her child and not following her own example of strong black motherhood and religious faith. Instead, Meridian follows the example of revolutionary black women like Harriet Tubman and her own grandmother on her father's side. Through Meridian, Walker reveals the less newsworthy legacy of the civil rights movement: the countless voters registered by black and white volunteers who faced down racist violence to help black people gain the means to participate in the political affairs that defined their quality of life. Along the way, Walker shows how freedom is a practice and highlights the tedious but necessary work of revolution that, while it doesn't get headlines, is a part of the larger movement that helps give it shape and define its objectives.

This chapter is contextualized heavily by black feminist writing of the 1970 s, ' 80 s, and early 90's, during which some black women scholars wrote about changing communities and academia in much the same way Meridian did in Walker's novel. Meridian the novel and the particular post-1960s black feminism I present share a link to real-world activism that reveals what is (or can be) at stake in literary study. Lorde, Angela Y. Davis, Walker, Morrison, Patricia Hill Collins, bell hooks, and others produced criticism that links thought with action—or as the title of this chapter implies - intelligence with passion. Situating their work against the 1960s 
during which many of them first began to write and become active politically, these women provide a framework within which to imagine how literature can be read in a way that promotes social consciousness and social praxis. The fiction and non-fiction writing in this study comprises the intelligence needed to take responsible action, and the way in which it was written encourages readers to be passionate about and committed to change. Accordingly, "the word and the world" coexist in the mind to hopefully spark creative, cooperative, and sustainable methods of resistance against the cruelty of a world that can, at times, be subsumed by images of violence and terror, poverty and neglect. 


\section{Chapter One:}

\section{"A Real Dark Night of the Soul": The Armies of the Night and Postmodern Doom}

Now the standard cure for one who is sunk is to consider those in actual destitution or physical suffering - this is an all-weather beatitude for gloom in general and fairly salutory daytime advice for every one. But at three o'clock in the morning...the cure doesn't work — and in a real dark night of the soul it is always three o'clock in the morning, day after day. At that hour the tendency is to refuse to face things as long as possible by retiring into an infantile dream-but one is continually startled out of this by various contacts with the world.

F. Scott Fitzgerald, “The Crack-Up” (1936)

It was in "The Crack-Up," originally published in three parts in Esquire, that F. Scott Fitzgerald wrote the famous line "the test of a first-rate intelligence is the ability to hold two opposed ideas in the mind at the same time, and still retain the ability to function" ("The CrackUp" n.p.). Fitzgerald notes how "one should...be able to see that things are hopeless and yet be determined to make them otherwise" (“The Crack-Up" n.p.). Fitzgerald could easily have been writing about the end of the 1960s, which for many indeed signaled a "dark night of the soul": social movements had disintegrated into identity politics or paralyzing distrust resulting from FBI counter-intelligence operations; leaders and activists had been killed, assassinated by federal and state authorities or murdered by white supremacists; the US was involved in full-scale, devastating warfare in Vietnam, with young American soldiers - many teenagers or barely in their twenties — missing limbs or dead altogether, psychologically damaged from witnessing and participating in death; and the burgeoning TV and consumer culture threatened to transform the 
idealism felt by many of the era into commercialism, kitsch, and a return to the deadening status quo. ${ }^{1}$ These conditions, made worse by the general disillusionment of thousands of young people committed to change yet powerless to control the media coverage that defined them as radical, drug-addicted, unpatriotic and irresponsible children, turned the promise of the decade into a recognition, by many, of the futility of lasting democratic reform. ${ }^{2}$

Norman Mailer was among those who held such cynical views about the 1960s, and in The Armies of the Night (1968), his chronicling of the 1967 March on the Pentagon, he balances a postmodern doom concerning the future with a yearning for an America devoted to fighting against global tyranny in word and in practice. In Armies, Mailer's gloomy disposition results from what he sees at the time as a resounding defeat of democracy by the burgeoning fascism characterizing US state policy. His account is complicated by historical positioning; without the benefit of hindsight, Armies does not acknowledge the gains in civil rights (especially in voter registration for African Americans) and in establishing equality for women and the GLBT community resulting from 1960s activism, or how national attention momentarily shifted to the interrelated issues of racism, sexism, poverty, and violence that plagued the country.

In 1968, Mailer saw the above issues as symptoms of a society in decline. He was part of a growing number of American writers (along with Thomas Pynchon, Philip K. Dick, Joan Didion, and others) whose work depicted the US as obsessed with technology and bereft of values. In her survey of American fiction since 1960, Kathryn Hume refers to what she calls a "slough of despond" (1), in which many authors "exhibit...[a] spiritual recoil from America" (3). In short, she examines how a multitude of authors have responded to the demise of the American Dream — which she defines as "fairness, material comfort, and freedom" (4) — and how the desires shaped by and through the Dream and its failures have led to an overwhelming spirit of 
disillusionment with the promises of American democracy. Hume sees the ' 50 s and ' 60 s as the beginning of what she calls a "new cycle" of a "liberal moral uncertainty" (5). She labels the "dreamers" awakened by this uncertainty and by the civil unrest of the 1960s the "Generation of the Lost Dream" (8). Mailer does not necessarily identify himself with this generation; in fact, he is best seen as a transitional figure in the postmodern literary period. In Armies, Mailer seems to be caught between an older generation of more conservative, academic leftists and a new, idealistic (yet, to Mailer, naïve and drug-addicted) generation of student activists. The conservative contingent of the march is marked by its preference for rallies and oratory, whereas Mailer views the student movement as characteristically more theatrical and directly confrontational.

Accordingly, Armies offers readers a view of the 1960s that catalogs and responds to the changes in politics and sentiment during the post-World War II and Vietnam eras. It is a postmodern text in content and in spirit; Mailer questions the nature of "truth" throughout, relying on irony and parody to undermine the rhetoric of resistance while defending the necessity of resistance in practice. Armies also critiques the increasing role of technology in daily life and argues that faith — in terms of religion — has been perverted into a faith in progress through technology. The war in Vietnam is a symptom of this perversion in the book, a war Mailer understands to be the beginning of an apocalyptic turn in American policy. Armies is Mailer's warning to the world that totalitarianism has the power to corrupt democratic progress and that human rights — instead of being universal — are contingent on the historical moment. As a product of a particular moment, Mailer's text displays the growing cynicism and doom that came to define postmodern intellectualism, which views consumer and digital culture as a revaluation of traditional mores built around humanist ethics, religion/spirituality, and community. Mailer's 
pessimism in Armies is a response to the loss of these values in American life, and the text—with its ominous ending depicting a nation pregnant with hope or doom-is a call to reclaim those values before it is too late.

Accordingly, the Norman Mailer in Armies — both the character and the authorembodies a split personality that I will argue is representative of a kind of postmodern pragmatism that retains the necessity of values in an era of revolution. One part conservative, one part radical, Mailer points to the radical possibilities of revolution while critiquing the antitraditionalism of radical thought. For example, he laments the manner in which he assumes the US has abandoned Christian ideals for the pursuit of power and world supremacy but simultaneously is revolted by totalitarian models of government, including strict religious authority. He longs for a grounding in traditional ethics and morality while acknowledging that, in many ways, those traditions must be revised to account for past (and future) atrocities such as those occurring in Vietnam at the time of Armies. In the searching questions Mailer puts to the reader, and through the example of the March on the Pentagon, he imagines how a method of pragmatic social thought (and writing) might be achieved in which theory arises from experience and is tested through action. As a writer, Mailer argues that the fiction writer can inspire depth through putting readers, vicariously, through the experiences of revolution. In Armies, Mailer reaches out of the "slough of despond" in part to ask what responsibility, if any, the literary world has in righting the course of the twentieth century. It remains an important text because of its descriptions of the spiritual, political, and social ills that spilled into the American streets in the 1960s and its prescience in anticipating the ways in which American authors would respond to the 1960s through a mode of pragmatic literary activism that I outline in this and subsequent chapters. 


\section{American Nightmare: Mailer as a Transitional Postmodern Figure}

In An American Dream (1965), Norman Mailer presents a vision of a person divided: the novel's protagonist — Stephen Rojack — is a war hero, former congressman, talk show host, and a member of New York City's elite, but shortly into the novel he becomes a psychotic, rampaging murderer on the run from the police and the mob, taking his directions from the moon. After the moon tells him to kill himself, Rojack murders his wife, Deborah, before participating in a long series of events characterized by sex and violence. Told in the first person, An American Dream offers no judgment on the actions of its anti-hero and privileges a view of America in which the power of evil fuels political and financial ambition. ${ }^{3}$ Moreover, many of the novel's charactersincluding Rojack's father-in-law, Barney Kelly, a wealthy businessman, and Rojack’s lover, Ruta (who is also Kelly's mistress) — are said to be in league with the devil. The ending of the novel, in which Rojack is not "good enough" to pull down the neon "spires" of Las Vegas (a symbol for a perverted American Dream), has Rojack leaving the United States for Guatemala, as his spiritual quest cannot be fulfilled in a land that offers no redemption.

The division in Rojack is a symptom of an American condition in which success is defined in terms of personal wealth and status overshadows ethical responsibility. ${ }^{4}$ Kelly's fortune, one learns, comes to him because of a supernatural power to predict the rise and fall of stocks; this power, however, was obtained from the devil after Kelly consummated an incestuous relationship with a willing and eager Deborah, whose birth was also procured through a deal with Satan. Mailer's novel is not really about the death of the American Dream but its perversion; with Las Vegas as the symbol of hell on earth, Mailer urges readers to consider how organized crime, politics, and chance serve as the foundation of a new dream, albeit a nightmare for those searching for genuine connection with the human and spiritual elements of their surroundings. 
The corruption of the dream happens alongside the corruption of the American spirit, a theme to which Mailer would often turn throughout his career. This diseased America was no longer a work of fiction to Mailer when he published Armies three years later, and he saw his vision of Rojack's spiritual disintegration realized in his own efforts to find redemptive value in 1960s American politics.

American spirit is in low supply in Armies, which concerns the events leading up to and including the 1967 March on the Pentagon protesting the US role in the war in Vietnam. Mailer divided Armies into two books: book one, "history as a novel," in which Mailer recounts the events leading up to and including his arrest for crossing a police line at the Pentagon, and book two, "the novel as history," in which Mailer describes the events of the actual protest at the Pentagon as would an investigative journalist. In a parody of journalistic objectivity, Mailer writes about himself in the third person, and in much of the book he is part of a group including literary critic Dwight MacDonald and poet Robert Lowell. Together they are representative (to Mailer, at least) of America's best literary hope_-its best critic, best poet, and best novelist. Throughout the book, however, Mailer pits the generation of MacDonald, Lowell, and Mailer against a cadre of "middle-class cancer pushers and drug-gutted flower children" (47). He repeatedly refers to the "cancer gulch" of America, an image pointing to an eroding national spirit consumed with a rapidly growing sickness. He has recurring apocalyptic feelings as he first attends a pre-protest party at an academic's house, a protest event at the Washington Ambassador Theatre, the March itself (with a stop at the Lincoln Memorial before proceeding to the Pentagon), and, finally, to jail.

Like Rojack in An American Dream, Norman Mailer is a character in transition in Armies. He is, like Rojack, on something of a spiritual quest in an America that he thinks is 
simultaneously in excess of and yet totally devoid of meaning. In contrast to Rojack, however, Mailer assumes he will fail and chalks up his participation in the March on the Pentagon to his "own principle of war games and random play" and to a self-defeating mix of nihilism and existentialism (14). Both as a character and an author, Mailer is a man in transition; while The Naked and the Dead (1948) can be considered a naturalist text that anticipates post-World War II existentialism, and while Mailer has a certain nostalgia for the activism of the Old Left in The Naked and the Dead and in Armies, he acknowledges that he must, on some level, give in to the changing culture and become an unwilling participant in the (post)modern world. ${ }^{5}$ Since the 1960s serve as a common reference point for the beginnings of the postmodern era in literature, and since Mailer refers to America repeatedly as "technology land," it is useful to consider Armies as an early postmodern text in which Mailer captures the complexity of 1960s culture and the representative literary, social, and political attitudes associated with the decade. Because Mailer resists and chooses throughout to parody both literary style and contemporary politics, Armies remains an important foundational text of the postmodern period because of its blending of literary styles to convey the changing American landscape of the 1960s and the sense of play at the heart of Mailer's style.

Mailer celebrates the stylistic freedom often afforded to postmodern authors as he moves through the events he depicts in Armies. He claims to be a follower of Dwight MacDonald's notion that "the clue to discovery was not in the substance of one's idea, but in what was learned from the style of one's attack," and says this is the reason why his "style changed for every project" (37). Furthermore, Mailer rejects Roland Barthes's 1967 pronouncement of the death of the author, and Armies (published only a year later) refutes the notion that texts speak outside their intentions. Barthes's argument that "writing is the destruction of every voice, of every point 
of origin" (142) would signal the apocalypse for Mailer, who cannot resist the urge to write himself into his work and values writing precisely because of its capacity as a public forum for warring personalities. Mailer is an example of what Paul Smethurst refers to as the "return of the author" in postmodern texts, "where the author, for very different reasons, places himself in his work, coexists with the work, and appears to rather enjoy being part of the cultural product" (72). Smethurst calls this process "de-differentiation," since it is part of an overall cultural shift that also includes the rejection of distinctions between "high" and "low" art.

Mailer's blend of nonfiction essay and novelistic style in Armies also places him in conversation with others, such as Didion and Hunter S. Thompson, who embraced what Tom Wolfe called "new journalism" in the 1960s. According to Leo Braudy, these "two Mailers," one a celebrated journalist and the other an embattled novelist, are actually Mailer's attempt to come to grips with being a writer in a country that would rather criticize than praise its artists (11). Braudy elaborates by claiming that Mailer's style allows him the freedom to raise and respond to important questions in his work while allowing for the possibility that an "understanding of history might bring the fragments of the self together" (11). Mailer, indeed, is one of those authors - along with Kurt Vonnegut and Joseph Heller-whose early fiction centered on World War II, the conflict that for the first time made the imminent destruction of the planet into literal fragments a terrifying possibility. The existentialism that became entrenched in post-WWII fiction had, by the time of Armies, been usurped by the increasing popularity of new spiritual and social movements, and thus the work of Jack Kerouac, William Burroughs, and others, tinged in Zen and drugs, had more influence on the perceptions of some 1960s youth. ${ }^{6}$ Although Mailer, who was at times both radical and conservative, ${ }^{7}$ often criticizes the hippie subculture of the 
1960s, he extended both professional and personal courtesy toward their heroes - the Beats—in an uncharacteristically glowing review and defense of Burroughs's work. ${ }^{8}$

The postmodern elements in Mailer's work could be interpreted as Mailer's attempt to evolve with the changing American literary and cultural landscape. ${ }^{9}$ His preoccupation with the rapid replacement of the natural with the artificial, and the corresponding links between technology and power, has much in common with authors such as Pynchon (the subject of chapter two). ${ }^{10}$ Additionally, Vonnegut's resounding "po-te-weet" at the end of Slaughterhouse Five (1969), signaling the collapse of language and narrative into non-meaning, was anticipated ten years earlier in Mailer's Advertisements for Myself (1959), when in the story “The Man Who Studied Yoga" the protagonist —a writer — cannot think of a coherent form for a novel and observes that he cannot write a realistic novel because "reality is no longer realistic" (179). Dick's science fiction novels, especially Do Androids Dream of Electric Sheep? (1968), are a testament to this unreality, and even as Mailer would continue to veer away from fiction and toward creative nonfiction, his views on American culture echoed the concerns of a burgeoning postmodern literary movement.

Armies explores fragmentation of the self and society primarily through three related issues: technology, identity politics, and the militaristic fascism that Mailer sees underlying state authority. Mailer spends a great deal of energy, in fact, confirming Leo Marx's observation in The Machine in the Garden (1964) that "for more than a century our most gifted writers have dwelt upon the contradiction between rural myth and technological fact" (354). Mailer begins his journey in Armies in what Marx calls the "machinery of our collective existence" (354) and feels throughout Marx's observation that "we have 'constructed a fate, an atropos'" which cannot be reversed (354). The central image in Armies and of the March itself — the Pentagon—is at the 
center of Mailer's critique of modernity: "High church of the corporation, the Pentagon spoke exclusively of mass man and his civilization...paradigm of the modern world indeed...the twentieth century was in the process of removing the last of man's power from his senses in order to store power in piled banks of coded knowledge" (255). The Pentagon in Armies is a symbol of American military prowess and of the ability of language to obscure reality. Indeed, the secrecy contained in the Pentagon Papers (smuggled out of the Pentagon by Daniel Ellsberg in 1969) revealed how America's foreign policy stance against communism shaped the public rhetoric of the war in Vietnam while the reality of decision-making about the war was kept from the American public. ${ }^{11}$ Mailer continues by pointing out how "the essence of coded knowledge was that it could be made available to all because only a few had the code to comprehend it" (255-56). Coded knowledge, also a feature of Pynchon's work, speaks to the limitations of language in uncovering the truth and also to the inseparable ties between language, knowledge, and power.

Mailer presents the Pentagon as a distinct feature of a postmodern society in which reality is increasingly hidden from view. The Pentagon's drab appearance and maze of hallways and offices provides in Armies a bureaucratic front to a building in which officials decide the fate of potentially thousands of lives - American and Southeast Asian-in a war that was increasingly seen as an American failure. Perhaps more than any other popular authors writing in the 1960s, Mailer and Pynchon spent much of their careers encouraging readers to seek out the truth hidden in government documents and in government policies not readily available to public view. In part, the purpose of 1960s activism was to demand involvement in government institutions and the authority to change those polices that marginalized and excluded American citizens in the democratic process. The Pentagon represents the dispersal of such authority among chains of 
information and bureaucratic positions meant to dissuade direct confrontation between the public and the source of state power. One of the critical problems Mailer addresses in Armies is the potential for such information to be encoded and multiplied infinitely in an increasingly technological society.

Uncovering the truth in Armies lies in revealing the "technological fact" that defines modernity in America. Mailer sees this as the writer's task; part of his critique of the liberal academic organizers of the March with whom he is tied is that they had no interest in a "real war with technology land" and "in all likelihood, they were the natural managers of that future airconditioned vault where the last of human life would exist" (26). Mailer sets a precedent early in the text for seeing technological positivism as analogous to or at least as a precursor to apocalypse. At the dinner party preceding the event at the Ambassador Theatre, he feels something artificial in the privileging of ideas over action, and in turn argues that academics are partly responsible for the artificiality and sterility of modern culture. He observes how "their living rooms had little to keep them apart from the look of waiting rooms of doctors with a modern practice" (26). Mailer's comparison of the living room with a waiting room reinforces his image of the academic as one who prefers to think rather than act, to detach from the outside world instead of live in it. As an author, he feels an ethical obligation to be in the crowd, among the people about whom he will soon be writing.

Mailer extends his argument about pragmatic social action when the party proceeds to the Ambassador Theatre, where Mailer is supposed to be the emcee of events. As he drunkenly moves toward the stage - arriving late after a long and well-documented journey to the bathroom-Mailer stumbles to the microphone and plays several different characters for the audience. He assumes an Irish accent in a profane parody of a blessing of the event and the 
crowd itself, whom he identifies as the "middle class plus one hippie," or, alternatively, the "middle class plus shit, I mean plus revolution...equal to one big collective dead ass" (50). He then peers about the room and asks, "Is there a black man in the house?" before announcing that he will have to represent the "impromptu Black Power for tonight" (50-1, emphasis in original). Mailer's absurdist performance as emcee, despite the mixed laughter and reprobation from the crowd and the organizers, is very serious in its intent and in the questions it raises about the nature of protest. How representative, for instance, can a protest be if it originates within the middle class? Just how diverse is the middle class in 1960s America? Where, indeed, are the black people? Are the "college heads" (50) in the audience sufficiently experienced in life to even begin to understand what is at stake? Mailer's objections are, to borrow from his own aesthetic method, over the style and content of the attack they are planning; the conceptual underpinnings of the proposed protest march—nonviolence, peace, and anti-imperialism—are diluted by the stratification resulting from the conscious and unconscious identity politics being played out in the theatre (which is itself, ironically, a house of performance).

The theatre is important not just as a site of protest events, but also in the name itselfthe Ambassador Theatre—and in its location in Washington, DC. The title of "Ambassador" generally implies some type of cultural or political emissary, and Washington is the center of power in the US. The symbolic promise of the event, therefore, is in reclaiming the nation's place of central power as an emissary of peace and progress; however, as the theatre is also known for being a psychedelic dance hall, the message is altered by its association with the hippie and drug cultures. It is perhaps his recognition of these shortcomings that leads Mailer to the parodic heights of his oratory, as when he refers to his own discursive style at one point as 
"shades of Lincoln in hippieland" (60). Yet behind the mask of self-deprecatory humor is a serious confession:

There was no villainy in obscenity for him, just—paradoxically, characteristically_ his love for America...not the America of course of the flag, the patriotic unendurable fix of the television programs and the newspapers, no, long before he was ever aware of the institutional oleo of the most suffocating American ideas he had come to love what editorial writers were fond of calling the democratic principle with its faith in the common man (60-1).

Mailer's performance at the theatre - in its postmodern amalgamation of identities—was an iteration of this longing for the democratic principle, which he did not observe in the white, middle-class comfort of the room.

The Ambassador scene also reflects another concern of radical politics: recovering geographical space in a symbolic gesture of redefinition. The practical purpose of the March on the Pentagon was to disrupt the activities of the war machine, to occupy the building in an official statement of American opposition to the war in Vietnam. The events at the Ambassador, located in the symbolic heart of American democratic ideology and practice, sought to take advantage of what bell hooks calls the "politics of location" (145). The protest attempted to recreate DC as a space of "radical openness," which, in its complicated and tendentious pairing of opposed identities and motives, is "a margin — a profound edge" (hooks 149). According to hooks, "locating oneself there is difficult yet necessary. It is not a 'safe' place. One is always at risk. One needs a community of resistance" (149). The kind of identity politics at play in the Ambassador Theatre obviated the possibility of the space becoming a "profound edge" simply because it was so safe. There was no risk involved in meeting there, especially as the theatre was 
already marked space; within DC, it was one of the designated areas of hippie subculture and, as such, was expected to be the site of such activities. The real act of protest, as Mailer explains to the audience, would be at the Pentagon itself, for as he warns, "'real heads may possibly get hurt, and soldiers will be there to hold us back, and some of us may be arrested"' (60). Mailer even asks himself how it would be possible to leave Washington now without being arrested (60), a thought that confirms hooks's pronouncement of the inherent danger of resistance to the state.

To Mailer, to walk the "profound edge" is to come closer to understanding the apocalypse, which he understands as the emergence of a techno-fascism in US state policy and attitude. The problem with resistance from within such a system is the power of the state (alternatively, "technology land" and "corporation land") to co-opt language and re-present it in what Mailer calls "totalitarianese": "any language which succeeds in stripping itself of any moral content" (315). This is also the language of the corporation, and of the media, and in many respects "totalitarianese" or "technologese" has already corrupted national dialogue in Armies to such an extent that it renders language meaningless except in how it reveals its own shortcomings; thus, when Mailer lists all of the various contingent groups he notices at the March — such as SANE, CORE, and Women Strike for Peace- he thinks that they "sounded like brand names which could have been used as happily to sell aspirin" (112). This "alphabet soup" (112) is at the center of Mailer's critique of the New Left, since it merges ideological differences (including the "worst aspects of Communism") and gender, age, and race-based identity politics with the sort of brand advertising that consumes the modern American mind (112).

Furthermore, once resistance is publicly displayed, it is immediately captured and packaged by mass media outlets for wide consumption. The misrepresentation of protests by the media is another symptom of "technology land" and is, in part, Mailer's impetus for writing the 
book. As Mailer, Lowell, MacDonald, and other "notables" are ushered to the front line of the March, Mailer observes how this row is to be "consecrated for the mass media" (105). In Armies the media is representative of a nation that has sold its soul or spirit to the promise of technology. Mailer sees the proliferation of information at high speeds as an extension of the "coded knowledge" of the Pentagon, particularly because the largely corporate-owned media is itself mediated through the power dynamics of the state. "Freedom of the press" in Armies is little more than freedom to produce the kind of news that is beneficial to the national agenda, which (to Mailer, at least) is to discredit the anti-war movement and support the US military. According to Mailer, the media at the March on the Pentagon "created a forest of inaccuracy which would blind the efforts of any historian" and "an explanation of the mystery of the events at the Pentagon cannot be developed by the methods of history - only by the instincts of the novelist" $(245,284)$. He again blames the media, arguing that "incoherent" and "malicious" accounts of the events make an objective history "inconceivable" (284). Mailer makes an important distinction between history and the novel here; by referring to the "instincts" of the novelist, Mailer suggests that "history" presumes finality and detachment from human judgment, whereas the novelist allows that same history to come to life on the page and to evolve in the minds of readers.

The war in Vietnam signals the absence of such critical thought as Mailer equates the consequences of imperialistic and militaristic American politics with a national spiritual death. About Vietnam, Mailer states, “America needed the war. It would need a war so long as technology expanded on every road of communication, and the cities and corporations spread like cancer; the good Christian Americans needed the war or they would lose their Christ" (212). Here Mailer juxtaposes the image of Christ-the-Redeemer with the image of a malignant mass on 
the heart of America, for the "fever" omnipresent in America since the beginning "had left the blood, it was in the cells, [and] the cells traveled" (173). Throughout Armies, Mailer invokes religion — especially the notion of America as a "Christian nation"—-to drive home his point that America is in the grips of a spiritual illness. Mailer proposes that instead of finding Christ within themselves, more and more Americans are finding Him in the military strength and technological power of the US, which leaves them devoid of the spiritual strength needed to steer toward good and away from evil. ${ }^{12}$

Mailer's cynicism is partly a reaction to the loss of faith he observes in the American people. He perceives military action in Vietnam to be a symptom of this loss, for a Christian nation would lead by example, not by force. At times, he appears to eloquently fight for a return to American values only to be met with ridicule; when he is released from jail after being arrested at the March, for instance, he gives a speech that seems to fall on deaf ears:

Some of us...were at the Pentagon yesterday, and we were arrested in order to make our symbolic protest of the war in Vietnam, and most of us served these very short sentences, but they are a harbinger of what will come next, for if the war doesn't end next year... why then a few of us will probably have to take longer sentences. Because we must. You see, dear fellow Americans, it is Sunday, and we are burning the body and blood of Christ in Vietnam. Yes, we are burning him there, and as we do, we destroy the foundation of this Republic, which is its love and trust in Christ (239).

Mailer describes his speech in self-conscious fashion in Armies and narrates an inner voice that encourages him to use a religious analogy to shock his audience. At the same time, he is sincere; the reference to the body and blood of Christ utilizes the symbolism of communion to underscore 
the ways in which military action in Vietnam is in direct conflict with the nature of Christian fellowship and service. He implies that if the nation acts in defiance of Jesus's teachings, it is in danger of casting him out entirely. To be sure, Mailer is not interested so much in religious doctrine as he is in the failure of the nation to embody its own stated values, a failure he sees as a sign of impending doom in the form of the public's inability to distinguish freedom from an encroaching tyranny. Mailer's cynicism is further fed by media reaction to his speech, which instead of responding to his ideas uses irony to demean his credibility. For example, an article in The Washington Post responded, "Mailer said he believed that the war in Vietnam 'will destroy the foundation of this republic, which is its love and trust in Christ.' Mailer is a Jew" (240). In a culture that views him as alternately hostile, overbearing, egotistical, and radical (and, arguably, has good reason for doing so), Mailer's own cynicism seems an appropriate, if limiting, defense against a society he feels has largely abandoned common sense and moral purpose.

\section{In the Ironist's Cage: Mailer's Cynical Distancing from America ${ }^{13}$}

In Armies, Mailer appears to conclude that even unity in dissent is no longer possible in America. Mailer's America is divided among those who think for themselves and those who are brainwashed by corporation/technology land (which, to Mailer, is the majority), and Mailer laments how "the two halves of America were not coming together, and when they failed to touch, all of history might be lost in the divide" (179). Channeling Fitzgerald, Mailer concludes that it is indeed a "dark night of the soul" if "you had the illusion you could do something about it, and the conviction that not enough had been done" (179). Mailer's pessimism, however-no matter how justified — places him at a distance from those around him: "he felt disembodied from all proceedings - yes, he had a glint of the emotion; doubtless, he felt shriven" (179). Mailer's confession is not just his observation as a writer, but also a self-implication; through his words 
and actions, Mailer himself helps drive the wedge between the "two halves" of America. As a "disembodied" character in a novel about a real event, Mailer's cynicism is ultimately in danger of demeaning the March on the Pentagon even as he praises the spirit of the antiwar movement generally.

As a self-defined "left-conservative," Mailer chooses from the outset of Armies to ostracize himself, and even in those moments in which he is uncharacteristically inspired by an act of courage by one of the protestors, he clings to an overriding sense of defeatism that is the product of his nostalgia for a pre-technological society - "an era when the message came by the wind and not by the wire" (173). Mailer's stance in Armies is distinctly that of an author who has, like Vonnegut, Pynchon, DeLillo, and others, lived through an era of unprecedented uncertainty in which the threat of nuclear war was imminent, and this uncertainty fueled Mailer's attacks on what he saw as an increasingly technological, totalitarian modern world. Even in the middle of the crushing weight of bodies moving toward the Pentagon, Mailer remains at an ironic distance from the events and from those involved, outside of the world of which he is also usually, paradoxically, the center. However, this distance is a symptom of the illness Mailer returns to throughout the text; as he witnesses those around him sliding into the "cancer gulch" at the center of American society, Mailer retreats in order to voice the call to reason that the nation (in his mind) so desperately needs.

Mailer's type of intellectual cynicism is ultimately unsustainable, as it offers little in terms of directly advising others how to live. However, such cynicism is of practical use in determining how ideology structures thought and behavior; the reader can thus view Mailer's suspicion of technology, "coded language," and radicalism as a stance that places limits on positivist constructions of social and political theory. Benjamin Schreier notes how cynicism 
"questions how knowledge is habitually put to use" (xvii) and, as an "apocalypse of enlightenment," rightly critiques the sincerity with which we can discuss and put into practice democratic ideals that continue to be reserved for the privileged (2). Throughout Armies, Mailer questions how knowledge is put to use and ultimately asks whether "knowledge" is attainable at all for the brainwashed citizens of "technology land." He asserts a love for America, but admits that his love is for a bygone era; his critique of "ideas" as social currency thus prefigures his resignation about the March, since the idea of America, to him, has been lost down the "cancer gulch." However, according to Michael Cowan, this "hard-won ironic detachment" also enables Mailer to reach the "sad yet humanizing understanding...that the dream of revolutionary adventure is itself an essential defining characteristic of the American tradition" (151). Mailer's cynicism is his defense against the modern age of advertising, psychedelic drugs, and middleclass revolution in which the idea of revolution often carries more weight than the act.

The Mailer in Armies is in what Michael Roth calls the "ironist's cage." In his book of the same title, Roth surveys recent trends in historiography to show how the late twentieth century suffered from a crisis of delegitimation of historical meaning. One of his primary examples of this trend is the work of Michel Foucault, who Roth claims "creates a pessimism at the expense of criticism... [and] undermines the possibility of making history meaningful, which may be essential for any kind of political action or judgment" (71-2). Roth's position is supposedly in relation to Foucault's written work, for as Brent Pickett observes, although Foucault was an activist for many causes, "the connection between those causes and his philosophy is obscure... and is at odds with his [published work]" (5). Roth argues, for instance, that Foucault's conception of historical meaning as "metaphysical," not tied to any social truth, "teaches us that we live without foundations" and ends up "dissolving the bases of our identity" 
(77-8). ${ }^{14}$ Poststructural thought thus leads to the creation of an ironist's cage in postmodern culture, which Roth defines as "the condition of the sophisticated cultural critic who no longer has criteria of truth or strategies of legitimation, but who continues to produce criticism" (172). Mailer is in such a cage in Armies, but his existential stance retains a glint of hope; in those moments when he identifies with and feels camaraderie with demonstrators, one gets the sense that Mailer longs to be part of the community he alternately rejects. It is possible that Mailer ridicules in Armies in order to teach, and future generations might learn from the mistakes of the good-hearted yet unprepared and perhaps irresponsible activists they meet in the text.

However, looking at Mailer and Foucault together makes one question Roth's definition of activism. If Foucault and Mailer are both writing about the discursive formations and practices of power-how they constitute "citizenship" and "patriotism," prohibit deviation from national narratives and myth, and prescribe ideal social behavior while placing certain behaviors (such as protest) outside the bounds of acceptable behavior - then their writing, even in its most ironic, might be considered a form of activism. In fact, the 1960s revealed the positivist narrative of American experience to be itself a myth; the image of thousands marching against a corrupt (some might say violent, even murderous) state points to the collapse of narrative authority. The challenge to authority in the sixties had as much to do with the power to craft history as it did legislation and policy, as the revolution marked a distinct chapter in the story of American democracy. Seen in this light, the cynicism of a writer like Mailer or Foucault contributes to the process of social change by encouraging the masses to question the status quo and to resist simply doing what they're told. It represents an alternative kind of knowledge, the re-education Mailer seems to suggest is necessary. 
Accordingly, Mailer shows how the American public is contained within authoritative discourses that prohibit critical thought. The post-WWII growth of America produced a technological revolution that seduced the majority of Americans into believing in a better, faster future, while the power of a nuclear arsenal seduced those same Americans into becoming obsessed with death. The "schizophrenia" that resulted from embracing the future as well as its negation led to a sickness in America, a declining spirit that especially affected the iconic American small town, which, to Mailer, represented the bastion of American ideals. Of these small towns, Mailer writes, "authority had operated on their brain with commercials, and washed their brain with packaged education, packaged politics" (103). The small towns, then, had become the arteries through which the lifeblood of power flowed and was cleansed; the corruption of which Mailer speaks is hidden behind the authoritative yet seemingly innocuous guise of a public education and the business-as-usual rhetoric of politics that never discloses the secret business of the government. Commercials, overloading viewers with useless information at high speeds, induced a type of paralysis of the mind so the brainwashing was more easily performed.

Mailer shows readers something that sixties activists may not have fully understood: successful activism first involves acknowledging and rejecting the tools of patriotism employed by the state to produce civic loyalty. He reveals how access to a public education as a right of citizenship is prefigured by a good citizenship that equates to political conformity; the "Pledge of Allegiance" is not just symbolic, but part of a rote memorization of the discourse performed by a patriotic citizen, part of the normative discourse of power that, again, is also a central feature of Foucault's work. As Mailer argues: 
Anyone who has passed through the educational system of America is in unconscious degree somewhere near half a patriot...the brain is washed deep, there are reflexes: white shirts, Star-Spangled Banner, saluting the flag. At home is corporation land's whip — the television set. Who would argue there are no idea-sets of brave soldiers, courageous cops, great strength and patriotic skill in the land of authority? (282)

Similarly, Foucault observes how knowledge "functions as a double repression: in terms of those it excludes from the process and in terms of the model and the standard (the bars) it imposes" (219). To Foucault, historical thinking that places the present only in relation to the past-instead of observing the immediacy of the present situation — serves to "dissolve the event," or, in effect, to hide the significance of contemporary actions behind their historical counterpart(s) (220). Such thinking reflects Foucault's distrust of discourse as an ordering mechanism for society, since discourse is inseparable from the language of power and its application through state authority. The discourse of protest is one of Mailer's most consistent criticisms of the March, which seemed to require speeches to mark every occasion; at the Lincoln Memorial, for example, he notices how everyone in attendance was "far ahead on Rhetoric," but how there were no "large demonstrations in answer to the speakers" (117). Mailer's distaste for "ideas" is thus similar to Foucault's notion that knowledge is always in the service of the teacher: discourse and knowledge both adhere to preconceived communities bent on self-preservation and the exclusion of "abnormal" or unwanted elements. Despite the seeming contradictions between their written work and public activism, Mailer and Foucault reveal the inherent value of cynicism to the intellectual pursuit of truth, defined by sixties novelist Robert Stone as "unresisted insight" 
(177). Ideology, defined and defended through rhetorical positioning, often limits the pursuit of truth outside of the bounds of its own dogma.

Because they both see revolutionary action as prohibited by an unconscious acceptance of learned civic behavior and coded knowledge, Foucault and Mailer reject the possibility that ideology can form the basis for a progressive society. Foucault contends rather that a "real socialization will emerge, in the twentieth century, from experiences" since "to imagine another system is to extend our participation in the present system" $(231,230$, emphasis in original). Mailer seems to agree in Armies, as his preference for style over substance finds an outlet in his political ideology: "The future of the revolution existed in the nerves and cells of the people who created it and lived with it, rather than in the sanctity of the original idea" (104). Foucault, for his part, argues that unity among dissenters can be found simply in the opposition to the present system, and Mailer sees the movement in Armies as doomed precisely because those taking part continue to disagree over ideology. Mailer writes of the "profound rifts" between generations and ideologies in the movement, as well as the bureaucratic machine that turns resistance into a wrangling over the time and place during and within which resistance can take place (248-72). Mailer writes somewhat prophetically of the "future schisms" that will undermine the movement: "the Black Militants were moving off by themselves, the Old Left was investing itself deep in the liberal purlieus of mass peace, and the New Left and the hippies were coming upon the opening intimations of a new style of revolution — revolution by theater and without a script" (249). In addition, Mailer notices a general lack of unity among Americans regarding Vietnam, which put increasing pressure on the already fragmented groups working together for protest. Popular support for resistance, generated through (or, to Mailer, more often countered by) the press is 
inconsistent and uncommitted at best in Armies, mostly because of a Western ideology that favors duality: good vs. evil, right vs. wrong, capitalism vs. communism.

When placed alongside Foucault's insistence on the conscious observation and critique of experience for sustained involvement in a movement, Mailer's notion of the "future of the revolution" being inside those who "created it and lived with it" points toward a useful model of pragmatism that unites theory with practice. Instead of an ideological foundation, this pragmatism would arise from a close, critical observation of experience and would evolve to meet the contingencies of the historical moment. Such a model addresses the fundamental argument of many 1960s activists: US democratic ideology exists as an idea that enables a false image of American exceptionalism in terms of civil and human rights, when in reality the practice of democratic resistance by marginalized populations is met with violent state resistance. Although Roth finds Foucault's philosophy unsuitable to progress (and would likely fault Mailer in the same fashion), Armies perhaps unconsciously moves toward an understanding of social democracy based in 1960s-era antiwar activism. The antiwar movement provided a common cause for resistance among diverse groups of Americans who came together to fight against the tyranny that preoccupied Mailer's thoughts in Armies. Mailer shatters illusions about the "Summer of Love" ideology concerning the 1960s to show how the legacy of the decade is steeped in freedom - freedom to love, to vote, and to protest the cruel actions of one's government. Ultimately, Mailer's frustration with the movement is a symptom of the inability of the American people to protect those freedoms put in jeopardy by unquestioned state power.

\section{Postmodern Ethics: Reading Against the Gloom in Armies}

The contrast between history and the novel that Mailer gives in Armies presents a different way to read the past as inspired by the social activism of the 1960s. "Objective" history 
or journalistic accounts can give overviews of past events (although Mailer distrusts their presumption of accuracy), but they remain, to Mailer, soulless examples of a static interpretation of experience. Mailer remarks that "the difficulty is that the history is interior...the novel must replace history at precisely that point where experience is sufficiently emotional, spiritual, psychical, moral, existential, or supernatural" (284). While a novelistic account is by no means more "accurate" in terms of the varied experiences of events, it is to Mailer's intimation more human and accounts for the "interiority" of experience often declared personal instead of public knowledge. In other words, a large-scale social movement demands the attention, sympathy, and creative instincts that only a novelist can give to events. One can expand Mailer's thoughts on historical experience to insist that the act of reading can itself is a political exercise, both in what one chooses to read and how one reads. Mailer urges readers to contemplate Armies and, by extension, other literature with the same emotional, spiritual, and moral energy that was put into the creation of that literature.

Mailer's focus on the "interiority" of history leads to an alternative understanding of postmodern ethics that counters the supposedly negative character of moral uncertainty. For instance, Zygmunt Bauman believes that the "frustration of certainty is morality's gain" (223). Although Bauman admits that "in America the shame of Vietnam boosted high-tech warfare much more than it did moral self-scrutiny" (227), he explains the development of "postmodern wisdom" that he defines as being "reconciled to the idea that the messiness of the human predicament is here to stay" (245). In the "postmodern habitat," as Bauman calls it, the only means for successful collective action exists at the local level, since global alternatives are-in his view_-doomed to end in division and disorder. Paradoxically, then, the postmodern condition has resulted in a collapsing inward; in a world that is more connected than ever before, 
individuals increasingly find that progress is most sustainable in their own local communities. Mailer's idea about the "interiority" of novels points to a community of ideas in which readers share the collective experience of the text. Moreover, Armies is an example of a text that combines ideas and actions by politicizing history and encouraging readers to understand the conditions of protest enabled by a failure to adhere to a shared understanding of moral behavior. Armies reveals how post-World War II America slipped into a reverie of victory over evil that blinded it to the potential for evil to arise at home, and Mailer's cynicism can thus be considered his realization that the "messiness" of the human condition is partly the result of such slips.

Mailer's insertion of himself into the text of Armies raises significant questions about literary production and scholarship. What is the role of an author? Does the text exist by itself, despite the intent of its author? How should one approach any particular text? Literary scholars have attempted to answer these questions and have offered a multitude of options for how to approach a text. However, while scholars cleverly dissect texts, the language of criticism is often exclusive and alienating; scholars exist in a "scholarly community," committed to a life of the mind while, as Cornel West contends, they "remain silent about concrete ways by which people are empowered to resist" (xxii). Likewise, Elizabeth Ammons points out how recent literary scholarship offers only instability: "nothing to hang onto, nowhere to stand" (3). Ammons refers to the influence of poststructuralism on postmodern literary study in concluding that the "continuing effect" of poststructuralist thought is that it has made "all textual meaning complex and unstable...frequently this has the convenient apolitical consequence of rendering impossible any clear, defended, activist standpoint" (6, emphasis in original). Although Mailer critiques language and ideology in Armies, he does in fact value some ideas more than others, especially when he faults 1960 s academics for what he sees as their retreat from any meaningful 
pragmatism. Liberal academics, he argues, place ideas above actions and hide behind the very words they argue have lost meaning.

From the very beginning of Armies, Mailer discounts the notion that the interpretive act alone_-generating ideas and concepts about social practices_- can have any relevant impact on the world. He derides academics whom he calls "servants of the moon,"15 for adhering to a "social machine of the future in which all irrational human conflict would be resolved, all conflict of interest negotiated" (27). Mailer's critique of liberal academia rests mostly on the carefully constructed and managed environments in which academics seem to work; indeed, he rightly points out how a white, upper-middle class model of liberalism at times operates within a concealed hierarchy of racial and socioeconomic power dynamics. At the party before the Ambassador event, he observes how he is "always depressed in such homes by their hint of oversecurity" (26). In other words, those with the ideas, those who pride themselves on intellectual work and maintain a safe distance from danger, are the ones who at the end of the day have nothing to lose. It is not their realities that they write and converse about, but instead those who are out on the streets, hungry, organizing against oppression and for better lives. To Mailer, the words of academics are hollow attempts at self-gratification, or perhaps just naïve displays of sentimental idealism.

Mailer's view of academia is one in which words are not defended with any meaningful, sustained action. Words have the power to transform as well as create realities, but they also have the power to foster exclusive communities in which the well educated shelter themselves from the public. As a writer whose own ideas are somewhat at the mercy of those who might teach his work to others, Mailer realizes this, and confesses that he despises academics "far more than he could afford to reveal (their enmity could be venomous)" (28). His opposition to 
academics, furthermore, is not just practical but also ideological; Mailer admits that his "private mixture of Marxism, conservatism, nihilism, and large parts of existentialism” was no longer compatible with "scholarly Socialist minds" (35). Mailer posits himself as a would-be misanthrope, someone who, perhaps out of writerly curiosity or plain boredom thrusts himself into the world of events to record and catalog the human tragedy around him. The events at the Ambassador Theatre, which were publicized in Time after his drunken performance as emcee, ${ }^{16}$ provide Mailer an opportunity to observe the shortcomings of others while ruminating on the only ideas that make any sense to him: his own.

Authors and readers are thus implicated in a process designed to encourage growth and discovery as opposed to the passive absorption of ideas. This method of reading can be connected to Mailer's critique of public education; as Jonathan Kozol remarked in The Night is Dark and I am Far From Home (1975), his polemic on the state of American education, "those who read in order to take action on their consequent beliefs - these are the only readers I respect or look for. Atrocities, real and repeated, proliferate within this social order. The deepest of all lies in our will not to respond to what we see before us" (33). Kozol's book connects the kind of reading (and writing) Mailer advocates in Armies to one of the issues Mailer identified as threatening the American tradition of social resistance. Additionally, both Mailer and Kozol participate in an American literary tradition of social protest; ${ }^{17}$ Mailer's objection to journalistic writing is perhaps the result of his disdain at "popular" literature that creates a common culture at the expense of literature that requires critical thought and, ideally, subsequent action.

The Armies of the Night is ultimately about recovery. Mailer's concern that history might be "lost in the divide" is his driving purpose in Armies, and the book represents his best attempt as an author to get at those "places no history can reach" (Mailer 319). His cynicism, which leads 
him to a defeatist attitude toward revolutionary action and social change, is perhaps best captured at the end of the book, when he imagines a group of naked Quaker anti-war activists praying in an isolation cell in a DC jail. Mailer wonders if their prayers could wash away the sins of America, but ends the book by declaring that "the death of America rides in on the smog" (320). However, Armies is an intervention into the process that makes history meaningless, a reaction to the sanitizing of events by a media complicit in state authority and the discourse of power. If Mailer the author, the "left conservative," entertains no possibility of significant change, one must take a cue from Mailer himself and judge not his attitude or his condemnation of ideology, but look instead to the book itself, to the act of writing. In producing a document that would save the antiwar movement and, specifically, the March on the Pentagon from History, from the forces of officially sanctioned "totalitarianese," devoid of any moral content, Mailer has contributed something of lasting importance to the collective memory of the time.

Finally, one must look to the title itself to fully grasp Mailer's purpose in writing Armies. The end of Matthew Arnold's poem "Dover Beach” (1867), from which Mailer takes his title, reads "for the world, which seems/To lie before us like a land of dreams/So various, so beautiful, so new/Hath really neither joy, nor love, nor light/Nor certitude, nor peace, nor help for pain/And we are here as on a darkling plain/Swept with confused alarms of struggle and flight/Where ignorant armies clash by night." To Mailer, America has long billed itself as the "land of dreams," but the dream is an illusion that hides the reality in which there is no "certitude" or "peace" or even "help from pain." If the history of American democracy has consisted of "confused alarms of struggle and flight," the 1960s were defined by struggle; Armies asks us which of these — struggle or flight - will characterize the modern age. Will we run from fascism, or will we fight? Will we recoil from America and each other, or come together in one of 
hooks's "communities of resistance"? As a fighter both on and off the page, Mailer puts readers in a position in the final pages of the text to ponder which side they are on. If the future will be shaped in the "nerves and cells" of the people, then Armies is an attempt to shock those nerves into responding and to take up the banner of activism from those who, despite naïve or misguided intentions, were nevertheless out in the streets marching for freedom. 


\section{Notes}

${ }^{1}$ For a discussion of the identity politics that proved divisive to social movements in the 1960s see Lytle, 269-316. For more on government repression of social movements, see Bud and Ruth Schultz.

${ }^{2}$ For an in-depth look at the media's impact on popular perception of the counterculture and of 1960 social movements in general, see Hilliard. Hilliard, who occupied several key positions in the federal government in areas of communications and education, explains the impact of media on society and the ways in which media outlets failed to directly confront authority. Also see Anderson, 241-91 for a good discussion on the origins, outlook, and media representation of the counterculture.

${ }^{3}$ An American Dream is, of course, not the only novel of the era to expose the corruption of the American dream; the best example remains William Burroughs's Naked Lunch (1959), in which America has always been corrupt, in which "the evil is there waiting" (11).

${ }^{4}$ In chapter 2, I provide a similar analysis of Don DeLillo's depiction of Lee Harvey Oswald in Libra (1988). There are, to be sure, plenty of examples of such characters in postmodern literature and film, and they are usually products of a postmodern culture of proliferation, multiplicity, and excess with no ultimate source of redemption. This culture induces an anxiety which leads to a psychotic break, thereby setting in motion a chain of events in which characters either seek to reverse the direction of modern culture or, foreseeing no hope for change, revel in the meaninglessness of their postmodern existence. Two popular examples of these extremes include William Foster (Michael Douglas) in Joel Schumacher's film Falling Down (1993), who rebels against the multicultural Los Angeles landscape in a flight against modernity, and Patrick Bateman in Bret Easton Ellis's novel American Psycho (1991, which owes much to Mailer's 
example), in which a young Wall Street executive embodies the sociopathic tendencies of capitalism and 1980s corporate excess.

${ }^{5}$ See Pizer, $90-115$ for a discussion of Mailer's trajectory as a novelist.

${ }^{6}$ See Skerl and Chandaraplaty.

${ }^{7}$ Mailer, for instance, was liberal in many of his ideas (especially in his stance against the war in Vietnam), but in other ways - such as in his views on homosexuality and his cavalier stance toward women — he was very conservative. See Millet, 314-336 for a famous critique of Mailer's chauvinism.

${ }^{8}$ In addition to positive reviews of Burroughs's writing, Mailer also testified at the obscenity hearing for Burroughs's novel Naked Lunch in Boston in 1966. This defense, again, contributes to the "de-differentiation" that Smethurst refers to; Burroughs's work, condemned by the state for political reasons but under the guise of an argument over aesthetics, had to be given cultural authority as legitimate art by those-Mailer and Allen Ginsberg—who were in a position to declare it appropriate.

${ }^{9}$ Mailer, to be sure, would have abhorred being labeled a postmodernist, and thus I use the label not to refer to any conscious stylistic, ideological, or political choice by Mailer as an author, but instead as a marker of the cultural attitudes and practices that he both influenced and which influenced his work and the public perception of his writing.

${ }^{10}$ My definition of "postmodern" in relation to Mailer most directly corresponds to. One of the foundational texts in postmodern literary criticism, Hassan's book rejects the sort of literary periodization that would separate "postmodern" from "modern" or even "romantic" writing. He explains how an author can produce both modern and postmodern work, since literary periods are both distinct and continuations of previous methods. His critique of Ernest Hemingway as 
something of a postmodernist (especially in his distrust of language and ideology) resonates with my own labeling of Mailer as a (perhaps unwilling) postmodern author.

${ }^{11}$ See Ellsberg.

12 The dynamic of a perverted, Westernized Christ is also presented in Adrienne Kennedy’s Funnyhouse of a Negro (1964), a surrealist play in which Christ appears as a yellow-skinned, hunchbacked dwarf - the physical manifestation of Western white religious corruption.

${ }^{13}$ Throughout this section, I use the terms "cynicism" and "irony" interchangeably to point to a willful detachment from idealism, and because as states of consciousness or attitude, I see them as mutually reinforcing (as in the progression from cynicism to parody).

${ }^{14}$ Foucault's "metaphysical" view of history can be interpreted as progressive in the sense that he acknowledges the contingencies of political identification and advocates a position not tied to any particular ideology. This position is more inclusive and is based on a simple resistance to tyrannical government practices; however, Roth's criticism is appropriate when one considers the centrality of historical meaning to, for example, African Americans, whose historical experience is an inseparable feature of the black activist tradition. Accordingly, many African Americans view the notion of "contingent" identities as an attempt to erase from historical memory the countless struggles for self-determination fought for by black people throughout American history. See, for example, Toni Morrison, Playing.

${ }^{15}$ Judging from his characterization of Rojack (a literal "servant of the moon") in An American Dream, Mailer links intellectuals to the madness that has crippled the American spirit.

${ }^{16}$ See "A Shaky Start."

${ }^{17}$ Nineteenth-century African American literature, especially what might be termed "radical" protest literature, is the best example of the tradition of social protest in American literature. For 
African Americans writing in the 1800s, authorship was indeed a political—and sometimes criminal — act that was often meant to catalogue and provide a necessary means of resistance to the white supremacist social order. See John Ernest, Chaotic Justice, for more on this tradition. 


\section{Chapter Two:}

\section{Reclaiming Community and Resisting Cruelty in Thomas Pynchon's Vineland}

Brood on that country who expresses our will. She is America, once a beauty of magnificence unparalleled, now a beauty with leprous skin. She is heavy with child - no one knows if legitimate - and languishes in a dungeon whose walls are never seen. Now the first contractions of her fearsome labor begin - it will go on: no doctor exists to tell the hour. It is only known that false labor is not likely on her now, no, she will probably give birth, and to what? - the most fearsome totalitarianism the world has ever known? Or can she, poor giant, tormented lovely girl, deliver a babe of a new world brave and tender, artful and wild?

— Norman Mailer, The Armies of the Night

Norman Mailer's final thoughts in The Armies of the Night reflect a suspicion he would repeat throughout the rest of his life, that "[f]ascism is more of a natural state than democracy" ("Only in America"). The post-World War II encroachment of the corporation into American life, the influence of TV on the popular culture it helped to create and maintain, and the increasing reliance of the United States on its military strength to secure international dominance led Mailer to conclude that something awful was on the American horizon. For Thomas Pynchon, Mailer's prediction was confirmed by the repression of the Nixon and Reagan eras and America's steady march toward conservatism in the 1980s. In Vineland (1990), Pynchon's long view of the 1960s looks at the leftist politics that preceded the decade as well as the backlash to the sixties that consisted of a fascist war on drugs, a complacent population addicted to the Tube, and a return to conservative family values epitomized by Reagan's re-election in 1984 . 
The characters in Vineland are all, to some extent, recovering from the fallout of the 1960s: the transition from activism to consumerism and from political culture to popular culture. They are similar to the characters in Orson Welles's Citizen Kane, who after Kane's death inhabit, according to James Berger, "a world of damaged survivors with damaged memories, living in the artificial harmony of a culture now dominated by the mass media Kane helped to found" (xii). Berger is writing about themes of postapocalypse in American literature, but is not so much interested in apocalypse itself as with the "aftermaths and remainders" of traumatic histories, such as the war in Vietnam and the violence of the 1960s (xii). Vineland, Berger contends, can be considered one of these postapocalyptic texts in the unique way it employs nostalgia: "Vineland returns to the 1960s not as to a site of original wholeness and plenitude but, rather, as to a site of catastrophe, betrayal, and cultural trauma... it is the traumatic past that persistently leaps forward into the present" (171). The novel is not, however, one long lament; instead, says Berger, Vineland's nostalgia is for the future, and it is infused with "ethical and political urgency" (171). This urgency develops from the premise that the conservatism of the 1980s was present even in those movements that professed a fervent opposition to American capitalism and abuse of state power. For instance, it was largely countercultural hero Jerry Rubin's public image in the 1960s that translated into his success as a Wall Street networking entrepreneur and, later, as an executive of a company selling packaged foods, bottled water, and operating under the banner of "multilevel marketing"- a fancy term for a pyramid scheme. Rubin is representative of the shattering of the illusion of 1960s innocence; all grown up by the 1980s, "flower children" had, in many cases, become the very business people, politicians, and social elite they once scorned. ${ }^{1}$ 
Pynchon seems to concur with Mailer that world politics tend toward conservatism and that people, in general, seek power and fame for the self instead of equality for all. However, there exists in all of Pynchon's novels an underground, a haven for the dispossessed who maintain networks of communication and resist the conformity of the dominant culture. Most important to my understanding of Pynchon's motives is Berger's use of the term "redemptive possibility" (172), which speaks to the capacity of memory to imagine possible futures; this imagining almost always originates in (or perhaps results in) the underground communities Pynchon establishes in his fiction.

On the surface, Vineland consists of two predominant narratives centered in and around the fictional Vineland, a logging county on the outskirts of California's wine country, in 1984. One is the story of Frenesi Gates, the progeny of two generations of leftist labor activists who, as the leader of an underground film collective and activist group in the 1960s, became an FBI informant and betrayed her friends and family. This narrative follows the attempts of her husband, Zoyd, to cope with her long absence, and her daughter, Prairie, to come to grips with her mother's past and abandonment of her. The second narrative follows one of Frenesi's collective friends - DL Chastain - and her partner, Takeshi Fumimoto, who participate in adventures while working as "karmic adjustors" for those whose lives are out of balance, particularly the community of "Thanatoids" (zombie-like figures trapped between life and death because of a past trauma) that symbolize the spiritual illness (as in Armies) devouring America. To connect the two, Pynchon employs antagonists in the form of federal agents Brock Vond and Hector Zuniga; Vond is the one who flipped Frenesi (and with whom she had an illicit sexual affair) and is in charge of several operations for CAMP (the non-fictional Campaign Against Marijuana Planting), which throughout the novel participates in military raids of locations 
around Vineland, and Zuniga is a Tube-addicted DEA agent who has tried to recruit Zoyd for years and who ends up directing an anti-drug movie that is a parody of the novel itself. The action of the novel revolves around Vond's targeting of Prairie in an attempt to locate Frenesi, now remarried to fellow snitch Flash, and with whom Vond becomes obsessed after federal funding for the snitch program is cut and she drops off the government's radar. As many of the characters in Vineland struggle to come to terms with modernity against a backdrop of 1960s-era nostalgia, Vond is symbolic of the fascism that has permeated US state policy and which continues to threaten the lives of those who seek to restore balance in their environments.

Vineland has received mixed critical attention, with many reviewers deeming it unworthy of the Pynchon oeuvre that includes Gravity's Rainbow, The Crying of Lot 49, and . $^{2}$ This criticism focuses on the perceived nostalgia with which Pynchon approaches his subject; he seems to long for an opportunity to go back in time to right old wrongs and reset the course of the latter twentieth century. Kathryn Hume identifies what she perceives to be Pynchon's dual criticisms of 1960s logic: the lack of real, definable goals (as opposed to the previous generation of radical-left activists and labor unions) and an "erotic response to power and authority" (170). In fact, Hume makes note of Pynchon's tendency in Lot 49 and Vineland to situate the erotic response to authority as a distinctly female problem (172). ${ }^{3}$ In the final analysis, Hume says, Pynchon faults the 1960s generation for the "political mistake" of "treating symbols as substance" (171). Symbols, however, do have substantive power-as the Pentagon did in Armies — so to fault the idealism of young activists is surely not Pynchon's central motive. Instead, Pynchon suggests that idealism is corrupted by its collusion with ideology and that the pairing often creates a weak foundation that cannot sustain activism. Vineland shows how idealism, broadly defined as a condition in which anything is possible, is undermined by political 
ideology that negatively influences the thoughts and actions of its proponents. Pynchon is one of several authors, along with Mailer, Alice Walker, Robert Stone, and others, who criticize countercultural movements of the era for loving drugs as much as (perhaps more than) they loved the causes for which they fought.

Pynchon's purpose in Vineland is in part to recover the power of the people and the necessity of community to resist repressive state authority. In recalling the 1960s from the conservative 1980s, Pynchon urges readers to adopt a watchful eye against government intrusion on civil liberties and thus reiterates Mailer's insistence that the future of protest is in the people who commit to fighting against oppression and not in the application of worn out ideologies to social problems. Indeed, Vineland shows how progress is anything but a given in the modern world, since every advancement in technology seems to come at great human cost (such as in machines replacing human workers, weapons technology resulting in higher and higher casualties, and the proliferation of methods of surveillance). In characteristic Pynchon fashion, he at once parodies everything in his line of vision (which is extensive) while never reverting to full-fledged cynicism. In fact, Vineland encourages readers to dream, cautiously, of the possibility of redemption. This possibility is dependent upon the adoption of a stance that is above all dedicated to the practice of freedom, which relies on a conscious resistance to cruelty in all forms. As a political novel, Vineland takes up the torch of 1960 s activism and posits that the act of reading is fundamental to personal growth and political education. It is anything but nostalgic; Pynchon portrays with both levity and seriousness the violence, tragedy, and chaos of an era remembered too often through the rose-colored glasses of manufactured TV culture and rejects the fanciful image of a generation of innocent, wide-eyed youth heroically standing up against state power. Instead, he creates characters and settings that encourage an empathic 
connection between the fictional world of the novel and the world of its readers, a connection which contributes to pragmatic modes of reading and scholarship and which rejects the privileging of the aesthetic over the political in textual production and criticism.

\section{Technofascism: Conservatism, the Tube, and the Possibility of Revolution}

Vineland requires that readers view the 1960s not as a time of any identifiable unityeither in ideological or practical terms — but as an era in which the possibility of revolution reached a tipping point, inspired largely by civil rights demonstrations and the antiwar movement. Indeed, there was not even one "revolution" to which the predominantly youthdriven counterculture was drawn; as Pynchon makes clear in the novel, the allure of music, drugs, popular revolt, and freedom from traditional civic and economic responsibility influenced counterculture devotees as much as the notion of a truly egalitarian society. At the heart of the novel is an exploration into what Fredric Jameson calls the "rhythm and dynamics" of the situation of the 1960s (179). Jameson uses the term "situation" to periodize the era, in which he argues the confluence of currents of history — political, economic, revolutionary — as well as philosophical and cultural cycles made the events of the 1960s a historical inevitability (178-79). Jameson's essay appears to have much in common with Pynchon's take on the sixties; both were published in 1984, and both dispense with the "traditional, narrative sense" often ascribed to distinct historical periods (Jameson 180). Jameson, like Pynchon, does not claim to represent History as it happened, but to develop a "concept of history" that accounts for the various contingencies that compromise linear narrative structures of the past (Jameson 180, emphasis in original). Jameson also looks back to the labor movement and identifies the 1955 merger of the AFL (American Federation of Labor) and CIO (Congress of Industrial Organizations) as a "condition of possibility" that led to 1960s activism, since, as Jameson claims, the merger was a 
"triumph of McCarthyism" that exiled communists from unions, created an apolitical relationship between unions and businesses, and privileged the rights of the white male labor force (Jameson 181).

Pynchon's novels often deal with the complexity of history, and his scenarios rely heavily on something similar to Jameson's notion of "conditions of possibility." For instance, as Zoyd reflects on his and Frenesi's extended "political family," Pynchon notes the "tragic interweaving" of powerful figures throughout history, representative of the "last unfaceable American secret, to be pressed, each time deeper...one blackly fermenting leaf on the forest floor that nobody wanted to turn over, because of all that lived, virulent, waiting, just beneath" (372). By the time of the novel, this leaf, uncovered in the 1960s when a large number of Americans assembled against their government, has again been buried beneath the forest floor. Vineland exposes the concept of history to be the story of human liberation (a story long familiar to African Americans and colonized subjects) in order to encourage readers to venture into the forest and look for the leaf themselves. Pynchon suggests the conditions of possibility are themselves not historically contingent and are always present just beneath the surface of everyday events. Accordingly, the conflict in Vineland is whether or not the current youth generation has the capacity to take up these conditions and fight back against an increasingly intrusive (and malevolent) federal government.

Mailer's apocalyptic vision of an America pregnant with the either/or of totalitarianism or democratic promise is a false dichotomy that Pynchon addresses through the character of Prairie, who in many ways represents the symbolic child Mailer imagines at the end of Armies and who, for much of the novel, traverses underground networks tied to 1960 s activist groups. ${ }^{4}$ She is a child born of the ambiguities and uncertainties of the 1960s; at fourteen years old in the novel, 
she would have been born in 1970, the year her mother became a paid FBI informant. Standing in between two extremes - her mother's sexual proclivity for authoritative men in uniform and her father's anti-establishment ethos — she is a manifestation of the contradictions of the American promise of revolution in a society controlled by a powerful elite. It is therefore useful to imagine Prairie as standing holding a scale in each hand; one scale represents fascism, the other liberation. In Vineland, Pynchon explores the critical and complex processes by which these scales are tipped.

The 1984 of Vineland confirms Mailer's vision of the future in The Armies of the Night; the ideals of the counterculture, co-opted and corrupted by the Tube and corporate America, have devolved into a "cold and diminished world of "commercial twilight"" (Chambers 184). ${ }^{5}$ The generational divide in the novel is the first indication one gets of just how perverted the counterculture's perceived message has become. As Zoyd mockingly questions Prairie about her punk rocker boyfriend, Isaiah Two Four, she responds that his name comes from a bible verse, “"which your friends his hippie-freak parents laid on him in 1967, about converting from war to peace, beating spears into pruning hooks, other idiot peacenik stuff"' (16). Here Prairie adopts a conservative rhetoric and even slides into the ironic, anti-Soviet language of 1950s-60s Cold War dogma with her use of the suffix "nik" to describe antiwar activists. Her comfort with such language reflects the conservative attitude of the Reagan era, as well as the distance between her generation and her father's. This distance is also characteristic of the 1960s, in which scores of youth rejected the conformity championed by a conservative, anticommunist 1950s; however, as Prairie demonstrates, her generation is instead rejecting the "hippie" culture of their parents in favor of the commercialism offered by 1980s popular culture. 
Isaiah Two Four is symbolic of the legacy of the 1960s from a conservative point of view, which saw the decade as consisting largely of attempts to violently overthrow the government and upset the institutions — marriage, family, church, military — that worked to define the American way of life. ${ }^{6}$ Indeed, Isaiah's 'business idea was to set up first one, eventually a chain, of violence centers, each on the scale, perhaps, of a small theme park, including automatic-weapon firing ranges, paramilitary fantasy adventures, gift shops and food courts, and video game rooms for the kids, for Isaiah envisioned a family clientele" (19). ${ }^{7}$ As Isaiah's name and demeanor suggest, the counterculture failed to inspire real, lasting change, and the current generation views the antiwar movement as nothing but a dislocated memory of their parents' irresponsibility. Isaiah Two Four's revolutionary ethos is not even anchored in the previous generation's anti-imperialist worldview; his "violence centers" instead are microcosms of US military actions in the third world. Additionally, his punk rock identity firmly anchors him in the commercialism of the 1980s, during which punk culture became mainstream and was sold in department stores.

In Vineland, then, as in The Armies of the Night, there exist two Americas: one in which idealists still cling to the hope of redemption, and another in which the cynics have taken advantage of the "apocalypse" of fascism to rise to political and economic power. Zoyd represents the former - those who are "still waitin for that magic payoff" - - while the latter is represented by DEA agent Zuniga, federal prosecutor/villain Brock Vond, and the ubiquitous network of commerce, politics, and television that brainwash the masses into complacency. These two Americas are symptoms of what Erik Dussere claims is Pynchon's notion of the "central drama that constitutes American history...the movement from boundless promise to endless betrayal" (578). For Dussere, Vineland invokes this "divide between two competing 
ideas of the nation - the madhouse reality and the indefinable alternative," through a historical moment that "must both be recuperated and questioned" (593). Dussere identifies two distinct transitions in the novel: the first is the transition from 1930s labor activism based on European social movements to the homegrown American radicalism of the 1960s; the second, which constitutes the trauma of the novel, is the shift from that democratically inspired radicalism to the conservative neofascism of the 1980s. In Vineland, the dark underside of the 1960s_- "War in Vietnam, murder as an instrument of American politics, black neighborhoods torched to ashes and death" (38) — has left both ideological and physical wounds, the wounds of "the spilled, the broken world" (267). ${ }^{8}$ Set against "those mythical days of high drama" (42), the present in Vineland is defined by disillusionment-as-reality, a depthless reality mediated by and through the Tube.

The obsession with television in Vineland is not just a lament of the technological takeover of the natural world, but is more significantly a critique of the image culture of the 1960s. Just as the antiwar movement adopted the v-for-victory sign (symbolically tied to WWII) in an ironic inversion of war and peace, the images of tie-dyed hippies, men with long hair, and of the counterculture in general were used by the media and by politicians to condemn the counterculture's seeming reversal of "traditional" American values. ${ }^{9}$ As Isaiah observes toward the end of the novel, "whole problem 'th you folks's generation...is you believed in your Revolution, put your lives right out there for it—-but you sure didn't understand much about the Tube. Minute the Tube got hold of you folks that was it, that whole alternative America, el deado meato, just like th' Indians, sold it all to your real enemies" (373, emphasis mine). When the counterculture movement was captured on film, in other words, it ceased to be alternative and became a parody of itself, entertainment for the rest of America. In addition, larger-than-life 
figures like Abbie Hoffman endangered the strategic anonymity practiced by some countercultural leaders and gave authorities both a target and, in his many interviews, speeches, and books, a look inside the movement's practices. As is usually the case with Pynchon, once a population or movement surfaces, it is helpless against the forces of fascism and commercialism that dominate the American cultural landscape. Since the media in Vineland is complicit with state authority (as seen in the beginning of the novel when Zoyd's renewal of his state mental disability checks is contingent upon him dressing up in drag, with a chainsaw, for a now ritualized stunt in which he jumps through a plate glass window for the nightly news), the real power of the image is in the hands of the authority, who has the means to shape and disseminate it to the public.

Part of Pynchon's project in Vineland is to portray the 1960s in all its complexity, to rescue it from becoming a televised caricature of itself. ${ }^{10}$ The popular perception of the counterculture as believing primarily in experimentation with drugs, sex, and music is represented by Hector, whose dream is to "locate a legendary observer-participant of those times, Frenesi Gates...to make a Film about all those long-ago political wars, the drugs, the sex, the rock an' roll, which th' ultimate message will be that the real threat to America, then and now, is from th' illegal abuse of narcotics" (51). Although a humorous passage, Pynchon's intention here is to show how the US war on drugs, which gained popular support partly through the demonization of the counterculture and glorification of the police in the media, is the main component of the state's effort to undermine the civil liberties of the American population. ${ }^{11}$ The danger inherent in media culture is in Hector's framing of the 1960s; his notion of "long-ago political wars" is an attempt to historicize the revolution and thus place it outside of contemporary politics and is an example of the conservative mentality that drives Pynchon's 
writing in Vineland. Like Mailer in Armies, Pynchon uses the form of the novel to explore the "interiority" of 1960 s politics and to reveal how many of the concerns of the decade were part of a larger, ongoing effort at meaningful democratic reform.

Pynchon's critique of media culture also points to the possibilities — and danger —of using film to achieve the reform sought by 1960 s activists. In the novel, the revolutionary film collective $24 \mathrm{fps}$ films incidents of police brutality and other forms of political corruption to expose the officials who prevented social change. While Vineland makes clear the dangers of Tube addiction, Pynchon hints at the redemptive power of documentary video to capture, if only in momentary fragments, the spirit of the era. The manifesto of $24 \mathrm{fps}$ speaks loudly to this effect: "A camera is a gun. An image taken is a death performed. Images put together are the substructure of an afterlife and a judgment. We will be the architects of a just Hell for the fascist pig. Death to everything that oinks!'” (197). Some scholars note Pynchon's seemingly cynical take on revolutionary filmmaking, concluding that $24 \mathrm{fps}$ reflects his critical stance against those who preferred to be behind the camera instead of actively involved in staging protest. However, Hume's observation that Pynchon faults any revolutionary ideology that advised "treating symbols as substance" (171) accounts for only a fraction of what is happening with 24fps in Vineland. Although generated by an idealistic spirit that underestimated the response of authority to documentary evidence of official misconduct, the $24 \mathrm{fps}$ footage in the novel acts as a vital bridge between past and present, a gateway through which the youth generation can approach a decade of which they have no experiential memories.

24fps is Pynchon's way of suggesting that film can also preserve memories and inspire curiosity and insight into the past. For example, when Prairie is in danger of being abducted and used as bait by Brock Vond to lure Frenesi out of hiding, Prairie and DL (her assigned protector 
and a trained ninja) visit another former collective member, Ditzah, who keeps archival footage of $24 \mathrm{fps}$ under guard in her home. Prairie watches the footage with interest and is carried back "to and through an America of the olden days she'd mostly never seen, except in fast clips on the Tube meant to suggest the era, or distantly implied in reruns like 'Bewitched' and 'The Brady Bunch"” (198). The following montage is worth quoting in full:

Here were the usual miniskirts, wire-rim glasses, and love beads, plus hippie boys waving their dicks, somebody's dog on LSD, rock and roll bands doing take after take, some of which was pretty awful. Strikers battled strikebreakers and police by a fence at the edge of a pure green feathery field of artichokes while storm clouds moved in and out of frame. Troopers evicted members of a commune in Texas, beating the boys with slapjacks, grabbing handcuffed girls by the pussy, smacking little kids around, and killing the stock, all of which, breathing deliberately, Prairie made herself watch. Suns came up over farm fields and bright-shirted pickers with the still outlines of buses and portable toilets on trailers in the distance, shone pitilessly down on mass incinerations of American-grown pot, the flames weak orange distortions of the daylight, and set over college and high school campuses turned into military motor pools, throwing oily shadows. There was little mercy in these images, except by accident—backlit sweat on a Guardsman's arm as he swung a rifle toward a demonstrator, a close-up of a farm employer's face that said everything its subject was trying not to, those occasional meadows and sunsets — not enough to help anybody escape seeing and hearing what, the film implied, they must (198-99). 
This is the real America, Pynchon suggests, and although film is by nature subjective, one gets the sense that what Prairie sees in the footage connects her to a time and place in a way she never experienced before. This connection to time and place also establishes a kinship with the figures in the film, allowing Prairie an opportunity to communicate on some level with the people and lives documented by her mother.

This fleeting connection to an era and its people is one of the moments in Vineland that urges readers toward something like kinship with those who fought for civil and human rights in the 1960s. Pynchon uses the camera eye in the above section to achieve an effect much like that experienced by Prairie in the novel: "At some point Prairie understood that the person behind the camera most of time really was her mother, and that if she kept her mind empty she could absorb, conditionally become, Frenesi, share her eyes, feel, when the frame shook with fatigue or fear or nausea, Frenesi's whole body there" (199). Pynchon establishes empathy through the 24fps imagery, revising postmodernism's (and his own) tendency to see image culture as signaling the decline of authenticity. Allison Landsberg argues that film can, in fact, be used in the creation of what she calls "prosthetic memories." These memories, "although they are not organically based... are nevertheless experienced...informing one's subjectivity as well as one's relationship to the present and future tenses" (26). Although this process can be seen as delegitimizing in some cases (as when Landsberg points to "immigration narratives" in which newly-arrived immigrants adopt, prosthetically, memories that would make them feel and appear more "traditionally" American, often at the expense of their own traditional culture), Vineland portrays the opposite through $24 \mathrm{fps}$ - the transfiguration of film imagery into mental imagery, a metamorphosis of the consciousness through an empathic connection to a bygone era. 
Characteristically, Pynchon interrupts Prairie's moment of clarity and connection to reinforce the notion of contingency as the primary antagonist of social progress. For Pynchon, there is a split between two basic ordering principles of the social universe: first, that identity, culture, power, and religious morality are relative categories based on historical contingencies, and two, that progress insists on a universal foundation of humanism and shared, communal value systems (based both on individual rights and democratic social governance). Prairie's encounter with the reality that the film "implied" she must see stands in contrast to the "suggestions of an era" she had witnessed through television—symbolic of the escapism of the postmodern sensibility. However, she is interrupted when both DL and Ditzah exclaim, “"Oh, fuck!'” as the film suddenly transitions into footage of Brock Vond in front of a federal courthouse (199). The fleeting solidarity felt by Prairie is presented alongside the image of power in the form of Vond, who represents the historical attempts of authority to promote solidarity only in the service of the national political agenda.

This relationship between contingency and solidarity is recognized by scholars such as Katherine Hayles, who observes how flashbacks in Vineland are "attempts to connect generations, to build or rebuild alliances across fatigued memories, broken promises, ruptured networks" (87). She further refers to the 24fps footage and the "power of the image to reconnect this history to a new generation looking for answers to some of the same questions" (87). Hayles refers to the "networks of kinship and friendship" (89) Pynchon develops in the novel, arguing that salvation will come not in a universal feeling of togetherness but in the commitment of individuals to promote shared values and progressive humanism in their own local communities. Understanding salvation in these terms reverses the Western, Christian notion of salvation as a passive status of grace-under-God, and instead points to an active, ongoing stance of radical 
resistance to state violence and threats to human rights. The possibility of revolution must be kept alive through the knowledge stored in and shared through the networks Pynchon imagines, as well as through the conscious practice of democratic protest.

\section{Reading Resistance: Barriers to Activism in Vineland}

In the novel, the counterculture movement of the 1960s is an amalgamation of contradictions that contained the seeds of its destruction. For example, the "free love" ideology often associated with the movement is corrupted in Vineland through very typical channels: jealously, infidelity, and an inability to distinguish between love and physical desire. The politics of the movement, loosely based on an anti-establishment ethos, is undermined by a reliance on recycled ideology. Additionally, the purpose or "soul" of the movement is corrupted through complicity with federal and state authorities and, in some cases, drug abuse. Like Mailer, Pynchon does not view recreational drug use as inherently wrong or immoral (as does the federal government), but criticizes the counterculture's misunderstanding of the effects of drug use on public perception of the movement and in establishing grounds for federal and state intervention and detention of movement figures.

Pynchon prepares readers to recognize the contingency of period-specific movements through a parody of grassroots uprising. He again takes readers into Frenesi's past, this time to Trasero County, California, along the coast between San Diego and Orange County. The conflict begins when a single marijuana cigarette causes mass panic at the conservative College of the Surf (which has been infiltrated by "surfer undesirables") and the police arrive and start beating unarmed students with riot sticks on the campus, which is located on the edge of a military base and features a hundred-foot-tall monument of Richard Nixon. Weed Atman, an unusually tall math professor, is first to notice the violence and leads students to the safety of an apartment 
rented by Rex, a graduate student and budding revolutionary. The students form a committee and learn through research that the university is the product of an "elaborate land developers' deal" that would, after five years, close down the college to build vacation units along the coast. In response, the students secede from the state of California and-in true Pynchonesque, absurdist fashion-form The People's Republic of Rock and Roll. The next day, 24fps shows up to document the proceedings while "young folks with subversive hair" put up posters and spraypaint $\mathrm{PR}^{3}$ on walls throughout the town (209). About PR ${ }^{3}$, Pynchon writes, "By all the laws of uprising, this one should have been squashed in a matter of hours by the invisible forces up on the base" (208). Instead, Pynchon saves the republic long enough to portray the issues that plagued activist organizations in the 1960s: the betrayal of movements by their followers and the concentrated, continuous attempts by local and federal governments to infiltrate organizations and disrupt them from within. Above all, Pynchon depicts characters on all sides as unable to navigate the contingencies of culture, identity, and politics as they work single-mindedly toward individual and collective goals.

When readers learn that Frenesi is actually sharing footage with and taking orders from Brock Vond in regard to $\mathrm{PR}^{3}$, Pynchon succeeds in juxtaposing a parodic tale of uprising with the very real and sometimes murderous campaign by the federal government to quell domestic uprising during the $1960 \mathrm{~s}$. The idealist sincerity of the $\mathrm{PR}^{3}$ uprising is captured, again, through Prairie's witnessing of the events through archival $24 \mathrm{fps}$ footage; as the novel turns back to Ditzah's apartment, Prairie watches a somewhat chaotic $\mathrm{PR}^{3}$ policy meeting/party and "could feel the liberation in the place that night, the faith that anything was possible, that nothing could stand in the way of such joyous certainty" (210). Pynchon, however, quickly intrudes to mention that Weed has a file in the government's COINTELPRO (Counter-Intelligence Program), the 
program through which the FBI and local police disrupted civil rights, antiwar, AIM (American Indian Movement), and student organizations, made false arrests, and, in some cases, outright murdered activists such as Black Panther Party members Fred Hampton and Mark Clark. ${ }^{12}$ In Vineland, Brock Vond alludes to these practices when, after meeting Frenesi in a motel room for sex, he tells her that "he had drafted, set up, and was about to have authorized a plan to destabilize and subvert $\mathrm{PR}^{3}$ with funding from one of the DOJ discretionary lines" (212). He refers to the republic as a "Marxist mini-state" and says that it would "have value as a scale model, to find out how much bringing down a whole country might cost" (212). Shortly after this exchange one learns that Vond does not simply want Weed Atman's body (which he says he will leave to Frenesi, who is also sleeping with Atman), but is really after his soul (213).

To Pynchon, the government's illegal intervention into the social movements of the 1960s was an attempt to weaken the spirit of activists, not simply to make arrests and ensure civic order. The plan, as Vineland proposes, was to make the very idea of resistance impossible to those who might consider questioning the status quo. For instance, Vond concludes that Weed is " "the key to it all, the key log, pull him and you break up the structure"” (216). Pynchon's narration then extends Vond's thoughts: "and the logs would disengage, singly and in groups, and continue on their way down the river to the sawmill, to get sawed into lumber, to be built into more America" (216). This passage reveals Pynchon's belief that federal authorities wish to control the thoughts and actions of "subversive" Americans in addition to physically confining them. After the narrative interruption of Vond's thoughts, Pynchon steps into Frenesi's as well. In the following excerpt, the novel moves from Frenesi's internal thoughts to the ambiguous subject pronouns "we" and "us": as she longs for Vond to show jealousy toward her relationship with Weed, Frenesi thinks, "It could've been about the only way she knew to use the word love 
anymore, its trivializing in those days already well begun, its magic fading, the subject of all that rock and roll, the simple resource we once thought would save us" (216-17, emphasis in original). Pynchon intercedes here on behalf of the hippie generation and penetrates the "wide invincible gaze practiced by many sixties children" (214) to reveal how the American dream, and in many ways the notion of childhood innocence, is corrupted through the networks of power that seek to turn the system against the people, and the people against themselves. The underlying message is that poverty, hunger, war, and oppression are central to the process by which nations are made and maintained and that there is always someone waiting just outside to make sure that resistance to such conditions is met with violent reprisal.

Frenesi's ultimate betrayal of Weed — and her role in his "murder"13 — is the key moment in the text in which Pynchon reveals the unsustainable nature of ideology. As Frenesi convinces a group of $24 \mathrm{fps}$ and $\mathrm{PR}^{3}$ members that Weed is an FBI informant, she says, “'Don't any of you kiddies understand, we either have 100\% no-foolin' solidarity or it just doesn't work. Weed betrayed that, and it was cowardly because it was easy, 'cause he knew we can't shut anybody out, down the end of that road is fuckin' fascism"' (235). In this passage, Frenesi is symbolic of the way power can appropriate the ideology and the discourse of resistance and turn it around on itself. Once the spirit of the movement is corrupted, the authorities easily disable $\mathrm{PR}^{3}$; Prairie watches the "scattered nightlong propagation of human chaos" accompanying the infiltration of the republic by police and soldiers in what is described as a "trapped and futureless night" that resulted in "scores of injuries, hundreds of arrests, no reported deaths but a handful of persons unaccounted for" (248). Prairie's faith that "anything is possible" is shaken by the footage, and, indeed, DL explains to Prairie their collective fear of a "final roundup" in which American "subversives" would be captured and transported to prison camps within the US. "'You've seen 
camps like this?"” asks Prairie, to which DL responds, "“Go to the library sometime and read about it. Nixon had machinery for mass detention all in place and set to go. Reagan's got it for when he invades Nicaragua. Look it up, check it out"” (264). ${ }^{14}$ It seems likely that DL's imperative is actually directed at the reader, and that Pynchon, like Mailer before him, is stepping into the narrative to implore his audience to become informed citizens. Prairie's feeling that "anything is possible" can also be read negatively: under a quasi-fascist regime, anything is indeed possible, especially the slow, systematic erosion of civil liberties the adoption of which fits a conservative civic and patriotic agenda. ${ }^{15}$

Through Prairie's experience with the 24fps footage, Pynchon creates an empathic connection with the past while also imparting the lesson that idealism, as a state of mind, can be manipulated, co-opted, and crushed by authority. The message — "anything is possible" — is both a message of hope and a warning, an authorial decree that attempts to reveal to readers the duplicity of ideology. Indeed, as "revolution went blending into commerce" (308), the revolutionary spirit of the 1960s in Vineland was defeated, at least temporarily, by Brock Vond and PREP, his "Political Re-Education Program," since "Vond's genius was to have seen in the activities of the sixties left not threats to order but unacknowledged desires for it" (269). In the novel, the "activists" of the 1960s—although well intentioned—were largely followers (and also very young), which meant that without leadership (assassinated or detained by the government), they were caught in a perpetual childhood, exposing them to the influence of an imaginary stability provided by state-sanctioned order.

In the end, it is again Prairie who symbolizes the precarious nature of freedom in the modern world. At the Becker-Traverse family reunion, an annual get-together of Frenesi's extended family in Vineland, Prairie — who is sleeping secluded in the woods — is almost 
abducted by Brock Vond, who dangles from a helicopter preparing to haul her away. However, just before he gets her in a twist that shows both the immediate power and arbitrary nature of federal authority, Vond's funding is cut, and the helicopter is forced to return without Prairie. As she drifts back to sleep, she fantasizes about Vond, willing him to capture her, saying "It's OK, rilly. Come on, come in. I don't care. Take me anyplace you want" (384). ${ }^{16}$ The scene ends in the morning, with various factions within the family coming together, working out differences, and with the return of Desmond, Prairie's missing dog, who wakes her up by licking her face. This representation of a fragile domesticity epitomizes the fragility of freedom in the US, and of the constant vigilance required to maintain it. Prairie's obsession with Vond can be understood as an example of the vulnerability of children and their susceptibility to authoritative control. Vond preys on this vulnerability just as federal and state authorities preyed on the vulnerabilities of the counterculture and other movements during the 1960s as part of secret campaigns to counter civil unrest and squash protest against the established order. The symbolic nature of the reunion is an important parting image, particularly since it signals the importance of family and community (broadly defined) in protecting children (and each other) from the forces that tip the cultural scales away from the good and toward, in this case, totalitarianism. One of the lessons of the sixties for Pynchon is that vigilance takes precedence over ideology, which can often blind one to the machinations of power; communities of resistance must remain focused on that resistance and not on adherence to paradigms that breed distrust and enforced loyalty to prescribed beliefs.

\section{An Alternative America: Looking toward the Future in Vineland}

Pynchon's social vision in Vineland is best understood as developing from a pragmatic approach to social philosophy. In Contingency, Irony, and Solidarity, Richard Rorty defines what a pragmatic social program would look like. He outlines a worldview dependent on an 
"opposition to cruelty" instead of on lofty appeals to a "common humanity," and Pynchon often seems to rely on the same sort of pragmatism. ${ }^{17}$ Indeed, part of Vineland 's appeal as a novel comes from its pragmatic approach to history and social activism, which concludes that ideology—as the basis of a movement—can only serve as a contingent marker of group identity, whereas sustained opposition to fascist governmental practices (without the need for a unifying theory as a guide) is in the service of a progressive humanism that does not circumscribe its practices with recycled dogma.

Rorty's use of the term "liberal ironist" also helps to further establish the differences between Mailer and Pynchon's accounts of the legacy of the 1960s. Rorty differentiates between the ironist- "who faces up to the contingency of his or her own most central beliefs and desires"- and the liberal ironist, who nevertheless cultivates a heightened sensibility and "the imaginative ability to see strange people as fellow sufferers" (xv-xvi). In other words, whereas Mailer seems to be strictly an ironist, Pynchon as a liberal ironist recognizes the futility of universal reasoning but attempts to fashion in readers an ability to empathize with the suffering of his inarguably strange and conflicted characters. He adheres to what Rorty calls "private irony and liberal hope" (73), which follows from a "sense of human solidarity" created and maintained through 'imaginative identification with the details of others' lives, rather than a recognition of something antecedently shared" (190). Pynchon, as perhaps the most notable postmodern American author of the twentieth century, revises the commonly held view that postmodernism promotes irony and detachment over progressivism and solidarity. As Rorty suggests, literature and literary analysis are best situated to provide a means for an "imaginative identification" with others, and Pynchon's subtle, yet characteristic advancement of "liberal hope" offers a version of postmodernism that is both cynical and hopeful, that recognizes the ultimate absurdity of shared, 
universal truth in a world of contingency while also preserving the notion that human decency can be established through networks of mutuality and a commitment to civil and human rights.

In Vineland, Pynchon is careful not to overextend his idea of community to cohere with what some might call a republican ideal of family values and close relationships built on membership in church or civic organizations. In fact, community in Vineland (as in other Pynchon novels) is itself contingent and tenuous. This fragility of communal identity in a postmodern world is acknowledged by Barbara Herrnstein Smith, who argues that what Rorty's definition of solidarity misses is that "at any given time as well as over the course of anyone's life history, each of us is a member of many, shifting communities, each of which establishes, for each of its members, multiple social identities... a collage or grab-bag of allegiances, beliefs, and sets of motives" (168, emphasis in original). Smith argues for a definition of community that is "considerably richer" and more dynamic than what some scholars have suggested (168). Pynchon's fictional worlds often depict characters and settings in the type of collage to which Smith refers, and Vineland is rife with competing motives and allegiances throughout. Accordingly, the central question in Vineland might just be if any type of "community" is possible, especially given the backdrop of betrayal and ambiguity at the heart of the novel. Pynchon's notion of community in Vineland seems to answer in the affirmative and is influenced by the shifts in identity politics and communications technology that accompanied the postmodern era in American culture. What some saw as a weakening of traditional frameworks for communal identity (familial, religious) gave way to other forms of social identification, such as generational (Baby-Boomer, Generation X, Y [Millennials], and Z [the Internet generation]) and, increasingly, identification with subcultures inspired by television and consumer culture ("Trekkies," "soccer moms," etc.). Because postmodernity ushered in a sort of crisis of 
overidentification, Pynchon's focus in Vineland on intergenerational and international ties established through activism, music, and, above all, resistance to cruelty, points to a revised understanding of community that accounts for the paradoxical nature of postmodern relationships characterized by what can be called "proximal distance." Proximal distance is a state of being in which one is connected to others from whom one may be geographically separated through the networks of communication made possible by an increasingly digital world; indeed, the postmodern, globalized setting of Vineland suggests that one is never really alone, never disconnected from the events of the world or the suffering of others. Proximal distance also represents a way to view oneself in relation to others and opens up new possibilities for alliances among formerly disconnected peoples.

In the novel, the Kunoichi retreat is an example of the type of community Pynchon envisions in a postmodern culture. The mountainside retreat, established by seventeenth-century female missionaries and now run by a sisterhood of "ninjettes," has become home for DL since the dissolution of $24 \mathrm{fps}$. As a community, it establishes a code of ethics and behavior while offering a physical and spiritual distance from the surrounding chaos of the federal war on drugs and on the counterculture. The retreat started in the 1960 s as a cross between a self-help clinic and Oriental fantasy camp for those interested in Eastern culture (particularly ninjas); however, visitors are surprised when the sisters assemble onstage and, "Not only were most of them nonAsian, many were actually black, a-and Mexican too!” (108). However, despite its comic underpinnings, the retreat is depicted as a place for weary souls suffering from a "karmic imbalance" to restore their health and reconnect with the natural world. When DL arrives with Prairie, the latter's role as a possible redeemer is hinted at when she teaches the kitchen staff (the retreat is known for the "worst food in the seminar-providing community") how to prepare edible 
meals, their first being a spinach casserole (111-12). As is often the case with Pynchon, hidden underneath the humor in this passage is an example of the connections that bring people together: the casserole, itself made from found and disparate ingredients, is part of a ritual, cooperative process of food preparation that sustains the community.

In addition to being a multiethnic, cooperative community, the retreat is also a center of resistance to government surveillance and oppression. Sister Rochelle, the head ninjette, explains to Prairie how they "subscribe to outside data services" and have an extensive file on her mother (112). In the communications room, Prairie finds that she can bring up "photographs, some personal, some from papers and magazines, images of her mom, most of the time holding a movie camera, at demonstrations, getting arrested, posing with various dimly recognizable Movement figures of the sixties" (114). From these images, "Prairie would learn her mother's hands, read each gesture a dozen ways, imagine how they would have moved at other, unphotographed times" (114). Through the technology that characterizes the postmodern landscape, Prairie is able to connect with her mother in way that almost makes her ghostly presence in the novel materialize. The suggestion in the novel is that such images might work to make the "dimly recognizable" figures of history more visible, more "real." This possibility is a significant departure from Pynchon's view of technology as replacing the real with the artificial and represents an alternative way to approach an increasingly digital world. The possibility of using technology for good presents itself at the retreat, which relies on technology to counter the forces of authority that use it for surveillance and tracking purposes.

The Kunoichi sisterhood is an example of a community that consists of traditional values while being flexible enough to respond to changing social and cultural conditions. It responds to contingency through "common sense and hard work" and is representative, in some ways, of the 
community Frenesi envisioned but was unable to enact: she "dreamed of a mysterious people's oneness, drawing together toward the best chances of light, achieved once or twice that she'd seen in the street, in short, timeless bursts, all paths, human and projectile, true, the people all in a single presence" (117). The Buddhist nature of Frenesi's vision is realized at the retreat, which Samuel Thomas argues provides a "strong working model for contemporary resistance culture" (138). Thomas observes a "materialistic and immanent utopianism" at work in the sisterhood, a culture that is built on a solid foundation but recognizes the contingency within which it must constantly evolve (139, emphasis in original). He contends that through the Kunoichi, "we can being to recover - perhaps even re-politicize - a concept of freedom that, according to Adorno, 'can be defined in negation only, corresponding to the concrete form of a specific unfreedom"' (140, emphasis in original). A concept of freedom defined through negation fits, alongside Rorty's "opposition to cruelty," in an anti-ideology that reconfigures ethics not in terms of what one believes, but what one stands against; positioning oneself against cruelty affirms practicessuch as pacifism - and programs focused on social welfare that value life instead of attempt to control it. In this case, resistance culture is defined by the beliefs and actions it resists and not by a set of ideas that circumscribe its existence. Pynchon's postmodern social vision suggests that we dispense with idealism framed by static notions of freedom, justice, and progress and instead adopt a worldview that rests on the negation of principles which have been proven to inflict harm and the promotion of behavior that sustains, enriches, and consciously defends cooperative networks committed to civil and human rights.

Pynchon's work often features characters who directly confront and fight against the inhumanity of the late twentieth century, in which the artificial and dangerous character of technology seems to devalue human life. The influence of technology upon the modern world 
and the rise in genocide in the twentieth century have put a strain on our collective ability to conceive of the kind of kinship networks Pynchon writes about. Nevertheless, his fiction asks us to envision literature as a guide in our attempts to find healthy ways to approach the world, and literary analysis as a means of applying that guide to the real world. To do this, we must pay equal, if not more, attention to the practical use of literature than to its artistic merit, since aesthetic evaluation tends to overlook the pragmatic value of a text and its ability to affect the worldviews of readers. For example, David Cowart remarks that in Vineland "the polemics have little to do with the novel's art, which one sees in the indirection and economy that deliver this and other Pynchon works from the realm of propaganda and didacticism" (75). He further concludes that Pynchon's “art [is] far superior...to that of such novelists on the left as Dos Passos or Steinbeck or Vonnegut" and that it "commands the aesthetic interest of readers who may find the politics somewhat overwrought" (75). There is little value in the creation of a hierarchy of "novelists on the left"-who, in Cowart's historical overview, all happen to be white and male — at the expense of belittling the practical implications of their work. The above authors contribute to something far greater than an aesthetic tradition; they are all involved, to varying degrees, in producing literature that adds to a foundation of values and that raises standards of human rights and community.

Post-WWII American fiction has often been characterized by its dismissal of overt optimism in relation to human progress, and Pynchon's novels suggest that the horrors of history have not led to any significant advancement in human societies. However, Pynchon's worlds are not irredeemable, and the power of his fiction is in its cautious hope that humanity is capable of greater understanding. These worlds are disorienting and often comical, but they are similar enough to our own that we can imagine inhabiting them, and this is why the practice of reading 
ethically is part of a larger struggle to understand the world and our places within in it in ways that guard against the genocidal tendencies of human behavior. In addition to recognizing the complex patterns that mark our existence, Pynchon inspires readers to acknowledge those fleeting moments in which life surprises us and renews our faith in humanity. George Levine suggests that "Pynchon can be so intellectualized that we ignore...his most astonishing and overwhelming power, to imagine love out of the wastes of a world full of people helpless to love" (118). Similarly, Judith Chambers observes that "what empowers [Vineland] is Pynchon's response to the world's descent into coldness," which she argues is his portrayal of "simple, nonprescriptive virtues" such as "courage, intelligence and kindness" as well as "the acceptance of frailties, needs, and the mysterious otherness of others" $(185,187)$. Faith in the possibility of redemption is what keeps us going, according to Pynchon, and his writing encourages us to remain cautious and hardened but, at the same time, to never lose sight of qualities such as love and humor that can offer a momentary respite from suffering.

From a critical standpoint, Vineland urges readers to resist the alienating discourse of academic theorizing and adopt — when called on - a pragmatic approach to text that responds to the needs of those on the margins of dominant culture. As such, the novel is an intervention into the politics of reading in an age in which scholarly discourse often alienates itself from the nonacademic reader. Read this way, Pynchon delegitimizes academic jargon to privilege a method of reading that inquires about the value of a text in regard to a fuller understanding of democratic principles, human relationships, and civic progress. In short, Vineland encourages one to read ethically, to allow the text to question and even influence one's perception of the world and other people. Manifested in the physical world, these connections are a means of 
bringing people together and of keeping alive the conditions of possibility needed for us all to move forward into the "best chances of light." 


\section{Notes}

${ }^{1}$ See Chepesiuk, 182-98.

${ }^{2}$ See Thoreen, 215 for a summary of negative criticism of the novel.

${ }^{3}$ In his critique of female sexuality, Pynchon must be considered alongside Charles Johnson, who in Dreamer (the subject of chapter 4), similarly faults women for their alleged shortcomings and weak stance as activists. However, as much as Pynchon seems to fetishize women as either vulnerable to authority or as Quentin Tarantinoesque ass kickers, in Lot 49 and Vineland it is women who possess the mental and spiritual strength to diagnose and attempt to correct the disastrous course of twentieth century politics and social ills. Accordingly, Pynchon at times has more in common with Alice Walker (see chapter 5), who posits women as the redeemers of an ethically deficient and violent modern culture.

${ }^{4}$ Although Mailer's pregnancy metaphor offers a good frame for this chapter (which focuses on Prairie as the symbolic child of that pregnancy), I acknowledge that Mailer is guilty of reverting to a gendered understanding of nation building and national mythology that casts women out of an active role in American politics and social organizing. Mailer's construction seems to position women as passive vessels of a national purpose and ideology created by men; however, it is women who bear the brunt of military police aggression in Mailer's account of the March on the Pentagon, as he witnesses MPs target women at the front of the protest and smash their faces with rifle butts.

${ }^{5}$ There are numerous examples of the commodification of the counterculture in the text, such as how Prairie works at the "Bhodi Dharma Pizza Temple, which a little smugly offered the most wholesome, not to mention the slowest, fast food in the region" (45). In classic Pynchon fashion, such examples are both a recognition of the consumer takeover of the ideological and religious 
foundations of community and a critique of the stability of such foundations in the first place. Westernized Buddhism, for example, is associated primarily in the " 60 s with a misguided notion of Zen and dharma as embodied in the work of the Beats, most notably Jack Kerouac. See Skerl, 169-87 for a discussion of Kerouac's involvement with Buddhism.

${ }^{6}$ See Morgan, The Sixties Experience, 264-74; Busch; and Hilliard for more on the "right turn" of post-1960s America.

${ }^{7}$ Isaiah Two Four's "violence centers" could also point to the US role in aiding and training right-wing dictators and third-world revolutionaries throughout much of the mid-late twentieth century.

${ }^{8}$ Pynchon's "A Journey into the Mind of Watts," originally published in The New York Times in 1966, remains an important and clear-eyed account of racial politics in 1960s Los Angeles. In it, Pynchon notes how many African Americans do not have the luxury of escaping reality (as does the majority of the very postmodern L.A.), and that race riots and the condition of black communities are representative of the "real" America.

${ }^{9}$ Friedenberg provides an excellent context for the different viewpoints regarding the counterculture.

${ }^{10}$ Perhaps the most popular and widely-seen representation of the " 60 s is the 1994 film Forrest Gump, which stars Tom Hanks as a simple-minded man from rural Alabama who experiences the decade through direct involvement with Vietnam, the student movement/anti-war protest, and a meeting with a contingent of the Black Panther Party. This depiction presents an extremely conservative view of the ' 60 s, in which Black Panthers are gun-carrying subversives, student leaders (such as Jenny's boyfriend, Wesley, the president of the SDS at Berkely) physically abuse women, and in which the product of "free love" — epitomized by Jenny—is the newly 
discovered HIV. Tellingly, Forrest's future is secured through the capitalist system; his fortune from his (likely environmentally-devastating) shrimping business is ultimately increased exponentially by his investment in the fledgling Apple computers. In the end, Forrest Gump appears to advance the triumph of business over idealism, which coincides with a conservative ideology of the supremacy of the free market.

${ }^{11}$ The counterculture was, in a sense, demonized by association with drugs — such as LSD — which were seen in popular culture as precursors to madness, violence, and societal decline. The dangers of LSD were, for critics, dramatically symbolized in the figure of Charles Manson, sentenced to death (and later life in prison during a California moratorium on the death penalty) for the infamous, LSD-inspired murders of actress Sharon Tate and others in 1969. For more on Manson and drugs in the counterculture, see Faith, which documents the experiences of Manson family member Leslie Van Houten within the context of 1960s drug use and the spirituality of countercultural communities. Ironically, LSD was widely introduced primarily through the US military, which sought to unleash its potential as a psychological and chemical weapon.

${ }^{12}$ See Friedman, 223-52 for a concise summary of FBI COINTELPRO operations.

${ }^{13}$ Since Weed is featured as one of the Thanatoids in Vineland-those on the threshold of life and death, the ultimate sufferers of "karmic imbalance" - the implication is that Rex's shooting of Weed did not kill him, but instead that the act, caught on film, led to the dissolution of his spirit. For Pynchon, however, Weed's spiritual death — and that of the Thanatoids in general—is representative of the post-1960s American condition: a state of paralysis, an apathetic generation of consumers without souls.

${ }^{14}$ Most scholars would consider Pynchon too good a researcher to be strictly paranoid, and indeed DL's accusations hold a degree of truth in reality. An example is the Internal Security Act 
of 1950, also known as the Subversive Activities Control Act, sponsored by Senator Pat McCarran during the McCarthy era. One of the act's key points stated that US citizens who violated the act could have their citizenship revoked. President Harry S. Truman, who vetoed the act, called it a "long step toward totalitarianism" (trumanlibrary.org). Also, see Scott for a discussion of the 1979 creation of the Federal Emergency Management Agency (FEMA), REX 84, a 1984 military exercise in how to respond to the suspension of the constitution (considered by Reagan in the event of a US invasion of Nicaragua) and how to round up and detain subservices in the US, as well as various strategies enacted since 1950 to suspend civil liberties and house US citizens in detention facilities. In addition, M. Wesley Swearingen, a former FBI agent, describes seeing in Los Angeles a file containing 5,000 security index cards, many of which were created during the time of the Security Act of 1950 (officially repealed in 1971) and how the names of subversives were simply transferred from that index to a new one-ADEXfor the continued monitoring of suspected subversives. See Swearingen, 103.

15 The US government has often used times of crises to implement laws that undermine the civil liberties of US citizens and the human rights of non-citizens. While Vineland points to the war on drugs as one of these crises, Pynchon would undoubtedly see the connection between the Japanese attack of Pearl Harbor, WWII internment camps for Japanese-Americans, and the adoption of the Patriot Act after the terrorist attacks of September 11, 2001.

${ }^{16}$ Prairie's declarative to Vond_-"Come on, come in"-also recalls (and reverses) the famous phrase "Turn on, tune in, drop out" uttered by countercultural hero Timothy Leary in 1967 at the Human Be-in, a large hippie gathering at San Francisco’s Golden Gate Park. Leary, of course, was urging those in attendance to embrace an alternative lifestyle through "dropping out" of 
mainstream culture and through the use of psychedelic drugs, whereas Prairie is welcoming the intrusion of authority into that same alternative culture.

${ }^{17}$ Pynchon's novels often seem to settle on an "opposition to cruelty" as the kind of belief that can ultimately structure one's own approach to the world as well as serve as the foundation for, to borrow from Martin Luther King, a "beloved community." Like jazz musician McClintic Sphere's observation in $V$. that "the only way clear of the cool/crazy flip flop" was to "keep cool, but care” (393), Pynchon's attitude towards revolutionary social movements seems to align more with personal loyalty to small, dedicated communities rather than with mass uprisings. In fact, Pynchon's advice about responsible activism comes, again, through Sphere: "help without breaking your ass or publicizing it" (393). The message seems to be, as in Vineland, that power - in the form of the state — will always do the majority of the "ass breaking," so all that is accomplished through violence or large, publicized demonstration is the assured destruction of those who resist. Small, sustained acts of resistance, however, accomplished across networks of dedicated activist communities, would more likely ensure the long-term survival of a social movement.

${ }^{18}$ Pynchon's vision is seemingly troubled at times by his characterization of women as either "ass kickers" or obsessed with authority and vulnerable to power. He seems to fetishize women at the same time he sympathizes with the complexity of living in a gendered culture historically dominated by males. Frenesi's sexual attraction to power and DL's ass-kicking sexuality both seem to cohere to male fantasies of either passive or domineering women. However, key moments in the text show Pynchon's awareness of the use of women as symbols; for instance, Brock Vond's recurring nightmare about being raped by a feminine alter-ego (the Madwoman in the Attic) points to Pynchon's acknowledgment of male anxieties concerning gender and power. 


\section{Chapter Three:}

\section{Maternal Historiography and Cold War Citizenship in Don DeLillo's Libra}

This is from oldentimes, that the men will kill each other and the women will be left to stand at the grave. But I am not content to stand.

- Marguerite Oswald, in Libra.

Derided by conservative critics as "an act of bad citizenship," Libra (1988) portrays the assassinations of John F. Kennedy and Lee Harvey Oswald through a painstaking reconstruction of the events leading up to the shootings. Working from documentary evidence-including the Warren Commission Report, transcripts from interviews, Oswald's "historic diary," and other materials-DeLillo presents "the seven seconds that broke the back of the American century" (Libra 181) in all its complexity, ultimately discarding the "lone gunman" theory to uphold the conspiratorial version of history. In DeLillo's novel, the Kennedys epitomized a fantasy world, their White House the Camelot of a mythical, imagined U.S. supremacy. That Lee Harvey Oswald, a working-class guy with a working-class rifle, was able to get close enough to power to take it out, was both perversely symbolic of the American tradition of revolution and a symptom indicating that not all was well with the country. Oswald was, indeed, an American product, created through the sweep of a revolutionary history and shaped by the forces of poverty and political discontent.

The Lee Oswald of the novel—whom DeLillo portrays as a complex figure embodying multiple personas - is impossible to pin down. Libra does not necessarily attempt to prove or disprove the historical possibility of a large-scale plot to kill JFK, but discovers the conditions under which Oswald — the man and the myth—came into being. The assassination backstory itself is largely just a smokescreen that purposely distracts from what is DeLillo's real message, that 
“Oswald is ourselves painted large, in scary tones, but ourselves” (Lentricchia 205). DeLillo's Oswald — whom Frank Lentricchia refers to as "the genuine American article" (199)—is a composite born of the modern American experience, a product of economic and social disparity frustrated with the broken promises of a morally bankrupt capitalist democracy who seeks refuge in a world of self-indulgent fantasies. Countering the popular mythology that pits the hero (Kennedy) against the anti-hero (Oswald) in a simplistic, overdetermined tragedy of derangement and betrayal, DeLillo constructs an open-ended and multi-level narrative that defers judgment and rests on no final, comfortable resolution to what was, and what remains, a defining and traumatic moment in American history. Therefore, although the dominant voice in Libra remains that of Lee's mother Marguerite, who appears in monologic form periodically in the text (detailing her family's victimization by circumstances, her previous husbands' abandonment of her and her sons, and, most of all, the country's betrayal of her family after Lee's death), DeLillo complicates her memories of Lee (both real and, perhaps, constructed) by characterizing him as a product of various, competing interests.

DeLillo has remarked that his sensibilities as a writer were shaped by the social and political climate of the 1950s and 60s, and in Libra he highlights the tensions resulting from (and central to) the Cold War US nationalism that dominated the era. Nationalism, in any form, relies upon an adherence to behavioral patterns and posturing that forms a distinction between the nation-as-self and the foreign other; the foreign, however, is not necessarily that which exists outside of physical borders, but more importantly that which is not confined within the borders of nationalist ideology. ${ }^{2}$ Borrowing from Walter Benjamin, Lauren Berlant argues that the conditions for constructing these differences arise from the creation of "abject populations," a process that leads to what she calls "hygienic governmentality," in which society is warned of 
the dangers of those abject populations to the national good (175). In the US, these populations have largely been constructed, again, through difference: the patriotic, white, Christian, nuclear family is the arbiter of normality by which all others are judged. Thus, the notion of "hygienic governmentality," as explored by DeLillo in Libra, is perhaps best viewed through what Michael Rogin calls a "countersubversive tradition" of "political demonology" in American history; in relation to women's place in Cold War ideology, Rogin states that "domestic ideology justified women's confinement in the home by making mothers into the guardians of public morality" (5). The dual focus on the idealization and condemnation of motherhood resulted in a "demonic version" of domestic ideology in which mothers were blamed for creating - to use Berlant's term-unhygienic homes that did not fit prescribed models of domesticity (6). DeLillo establishes these conditions in the novel by invoking the notion of containment, principally in his characterization of Marguerite, who is positioned as the antithesis of Cold War era republican motherhood.

Much of Marguerite's monologue in Libra is inspired by or taken directly from her testimony in front of the Warren Commission, during which interviewers became increasingly exasperated with the real Margeurite's unwillingness to provide direct answers to their questions. DeLillo's use of her rhetorical style in the novel effects something akin to transposition; while the tone of her words remains the same, the absence of an audience to pass judgment in the novel invites readers to re-imagine her life with Lee. Libra thus criticizes the ways in which historical narratives impose identities upon individuals; containment — a keyword of the Cold War-is disrupted by Marguerite in a public, performative display of motherhood and patriotism meant to clear her son's name and restore her family's status as proud Americans. Demonized as the woman who produced Kennedy's assassin, Marguerite defends her family's name in Libra by 
invoking the rhetoric of Cold War domesticity while refusing to be contained within a narrative that equates the Oswald name with derangement and betrayal. Her narrative - at times contradictory, fragmented, hostile, and self-serving — nonetheless documents a mother's vision of her dead son while also revising the image of herself as a "bad mother." This also allows her to break out of the containment of the popular narrative structure that has her as a neglectful mother and responsible party in Lee's supposed derangement. By focusing on containment narratives through Marguerite, DeLillo reveals how "bad citizenship" is constructed by the discourse of power to prohibit critical questioning of authority and to respond to resistance efforts.

Containment is thus a strategy aimed at normalizing "hygienic" civic behavior; for the purposes of this project, Libra further highlights attempts by government to contain protest outside the bounds of acceptable citizenship and shows, again through Marguerite, how alternative knowledges are constructed that react to the prescriptive desires of authoritative discourse. The conservative reaction to the novel adds another level to this critique that underscores both the power of literary work to shape public opinion and how ideology is dependent upon historical narrative authority.

\section{A Mother Against the World: "Bad Citizenship" and the Construction of History}

"I have to tell a story," declares Marguerite Oswald at the end of the novel, "I am reciting a life and I need time" (455). The story Marguerite tells in Libra battles official and constructed memories of Lee in order to give an account of his life that coincides with her own experiential knowledge of her son. Her presence in the novel both counteracts the monolithic influence of the media and reveals the extent to which DeLillo sees history as fundamentally performative. If recording the past often serves agendas related to politics, nation, and identity — what Benedict Anderson calls the "shrunken imaginings of recent history" — then individual recollections such 
as Marguerite's recast history in terms of lived experience. ${ }^{3}$ Imploring her audience to consider that "my only education is my heart," Marguerite challenges the detached, objective view of life that historical study tends to posit as authentic or accurate, as well as the presumptive judgments of a class-obsessed nation. The heartbreaking recollections of her son and of her struggles with poverty and public opinion — including losing one husband to death and another to divorce, moving addresses every few months, being fired from a department store for "poor hygiene," having to place her sons in foster care or with relatives when money was tight, and having to, at many points, share her bed with Lee due to lack of space — point readers toward an alternative understanding of Lee Harvey Oswald as a son, brother, husband, and father, and not just the deranged killer that Marguerite feels America will come to know exclusively. Her desperate tone reveals the circumstances under which she labors; it is a mother's confession set against the channels of judges, policemen, forensic experts, psychiatrists, and public memory. As a radical mother, ${ }^{4}$ Marguerite rejects a patriarchal culture that would place her outside of history, especially in the male-dominated public history of the 1960s. Through her character, DeLillo highlights a form of maternal historiography that is central to US culture. ${ }^{5}$

Accordingly, DeLillo's radical re-reading of the Kennedy assassination potentially obfuscates another source of considerable value in the novel: its insistence on legitimizing nonacademic and unofficial histories and theories. Seen in this light, the conservative response to Libra was not just about DeLillo's "radical" authorship, but was also perhaps a rejection of the notion that a poor, villainized, masculinized mother could have anything of substance to contribute to American political discourse or historical memory. ${ }^{6}$ Marguerite the character thus encourages readers to adopt a similar radical stance against rhetoric and policy that undermines attempts at progressive social action. Her materialist, maternal politics in the novel point to all of 
the unacknowledged voices of women who, because of poverty, patriarchy, or patriotic hostility to critiques of American life, have had their concerns go unheard.

Marguerite's narrative closely resembles the actual Marguerite Oswald's testimony to the Warren Commission and her subsequent activities since the assassination (until her death in 1981), but its significance in the novel has been downplayed by a number of scholars. Magali Cornier Michael offers the most complete analysis of Marguerite's value in Libra, writing that her voice is "vital to the novel's subversive critical potential" (146, my emphasis). Michael demonstrates how Marguerite functions "as a means of grounding the characters and events in the material situation" (146) through an "adherence to the logic of cause and effect" and an "essentially feminist, materialist approach in asserting the inextricable link between the realm of the personal and domestic and culture at large" (147). Although this gives her a degree of selfdetermination, Michael notes how a pervasive media construction of her son's life ultimately deprives her of the agency she seeks (147-48). David Cowart, similarly, concludes that she sees herself as a "Mater Dolorosa"- or sorrowful mother, a reference to the suffering of Mary during Jesus's crucifixion —in an "especially dramatic and concrete instantiation" of Lyotard's maxim of the postmodern condition signaling the end of the master narrative (108-09). Joseph Tabbi writes that Marguerite "directs her appeal to the unseen, unlistening representative of American power" (193). Referring to her seemingly incoherent narrative fragments, Tabbi observes how "her words reverberate in the small room of history," but concludes that "her dotty logic heightens the book's claustrophobia" and doesn't open itself or the narrative up to "other voices" (193). Michael's focus on the novel's “potential” similarly argues that DeLillo's characterization of Marguerite falls short of achieving any sort of lasting political or historical significance. 
Conservative reactions to the novel, however, suggest otherwise. George Will, who referred to DeLillo as a "bad citizen" in the Washington Post, concludes his review of Libra with this observation: "It is well to be reminded by books like this of the virulence of the loathing some intellectuals feel for American society" (56). Will's comments concerning DeLillo's "leftist" ideology recall the anti-communist, pro-democracy nationalism that fueled 1950s and 60s politics. The mythology of the Kennedy White House was instantiated in history through the creation of a national narrative of betrayal that imagined a demented sociopath and communist against a true American hero. This narrative was an example of what Priscilla Ward calls the "official stories," or the formulaic but always-changing tales that "constitute Americans" and "determine the status of individuals in communities" (2). In this tale of good vs. evil, capitalism vs. communism, Jack Ruby emerged as both a patriotic son and an alleged mafia hit man, while various conspiratorial counternarratives questioned the legitimacy of the lone gunman theory. DeLillo identifies the assassinations — and the corresponding media saturation—as the premier postmodern events and articulates "bad citizenship" (in Lee Oswald) as a distinctly American creation that is both the product of a sweeping history and of a national imaginary that glorifies violent individualism. $^{7}$

By providing insights into the logic of Oswald's actions, by showing the trajectory of his life to be both within and outside of his control, DeLillo fashions in Libra an image of America that threatens the solidarity of a nostalgic, "us vs. them" anti-communist era of American history. Marguerite represents this threat in the novel; she repeatedly insists that her family is an exemplary model of US citizenship, arguing that forces beyond her control (poverty and single motherhood) did not prevent her from functioning as a mother. Her strategic use of nationalist rhetoric — identifying the Oswalds as a "military family"—places the blame for Lee's actions 
elsewhere: "I love my United States," she says early in the novel, "I'm a person with no formal education who holds her own in good company and keeps a neat house...this is my defense" (67). Her patriotic ethos, combined with her domestic sensibilities, makes Marguerite a difficult subject, a hostile witness in a high-stakes trial to determine the historical memory of the Kennedy assassination.

Marguerite's attempts to actively construct (or, perhaps, revise) the public memory of her family display an understanding of the performative nature of nationalism and national identity. By identifying the Oswalds as a "military family," she is implicitly answering Kennedy's famous suggestion during his inaugural address to "ask not what your country can do for you; ask what you can do for your country." The Oswalds, she argues, did much for their country, and in a symbolic act of reversal insinuates that the indictment of her family name is an act of betrayal by an ungrateful nation. The nation, to be sure, had much to lose in the fight over how to represent the Oswald family; as Alan Nadel argues, the post-World War II US focused on containment as a means of crafting a national narrative that "promised a happy ending." In fact, Nadel says, "the policy of containment thus suggested that the narrative democracy contained would also 'contain' the spread of communism" (101). As the Bay of Pigs veterans and wandering mercenaries in Libra reveal, there existed in the early 1960s a nostalgia for the era of hardspoken anti-communism; the narrative of containment, weakened by Kennedy's softening position on Cuba, leads the conspirators in Libra to plot against the president to set right the course of the nation. If national identity is articulated through the creation of narratives that speak to a nationalist ethos, and if citizenship is then defined as the acceptable performance of roles provided through that narrative, then US identity in the 1950 s and 60 s was tied directly to the fight against communism. Kennedy's hard line against communism (both toward Cuba and in 
his decision to involve US troops more fully in the conflict in Vietnam) helped fashion that identity, and his assassination made the possibility of a "happy ending" seem out of reach. If, as Svetlana Boym contends, nostalgia is a "defense mechanism against the accelerated rhythm of change" (64), then the turbulence of the 1960s — and the emergence of counternarratives such as Marguerite Oswald's - created a crisis of identity in American life that countered the vision of the nation as a stable, unified force of democratic progress in the world.

DeLillo's bad citizenship as an author is, in part, determined by his sympathetic portrayal of Marguerite in the novel. DeLillo, through her character, revises the "narrative of containment" that became part of the national, democratic mythology. Marguerite Oswald's much-publicized and continued defense of her son Lee, as a subversive critique of popular historical narratives, is treated at length in the novel and positions the reader as sympathetic listener to her tale of patriotism and poverty. Removing state authority —in the form of the Warren interviewersfrom the equation and presenting her remarks out of context, DeLillo attempts to portray what he feels is the real Marguerite Oswald; although still a construction, the Marguerite of the novel confronts readers with their own presumptions and expectations, ultimately standing on her own as a believable and even empathetic figure. Her story as presented by DeLillo enables a more democratic model of historiography that privileges autonomy over authority and individual stories over grand narratives.

Marguerite's presence in Libra, therefore, destabilizes the grand narrative of the assassinations. In many ways, she is the same Marguerite Oswald who is depicted in Jean Stafford's A Mother in History (1966), an account derived from three interviews conducted with Marguerite in her Texas home in 1965, two years after her son's death. Originally an assignment for McCall's magazine and later revised into a short book, Stafford's account of Oswald has 
been criticized for what some perceive to be her obvious antagonism toward her subject. Indeed, Stafford alternately calls Oswald "strange" and "masculine," while also making note of her idiosyncratic speech patterns. ${ }^{8}$ Stafford's tone reflects the class differences between the two women, and at times she seems to mock Oswald's inability to clearly articulate her defense of Lee. With the assassination of JFK still a poignant memory in the national consciousness, Stafford's interviews betray her difficulty in balancing objectivity with her sense of patriotic duty; Stafford's "good citizenship" required, in other words, that she hold Marguerite Oswald in contempt for the sins of her son.

The dialogue between Stafford and Oswald highlights the connections between gender, citizenship, and performance that accompanied Cold War nationalism. Kate Baldwin claims that Stafford's book exemplifies how the Cold War dictated that women show a fidelity to a national, capitalist ethos through domestic performance, and that Marguerite's dialogue with Stafford provides an instance of "constitutive ambivalence at the site of nationness" (87). Identifying domestic Cold War policy regarding women as one of "containment" within the realm of the home, Baldwin cites the ways in which Marguerite's "performative acts and utterances" both display and reject her roles as an American mother and patriot. In doing so, Marguerite simultaneously resists Stafford's attempts to contain her within the domestic realm and becomes a "figure for the dismantling of an era's supposed certainties" (88-9). Accordingly, Marguerite Oswald - the woman and the character — offers a maternal historiography of resistance that reclaims the private image of her son. The now familiar cry that "the personal is political" resonates with Marguerite's efforts; she remakes the site of home - the realm of domesticityinto a political arena by fighting for control over how that space is perceived in public memory. 
Importantly, DeLillo - through Marguerite - shows how the personal, private space of the home is not just merely political, but is an essential part of the foundational politics of the Cold War. DeLillo's focus on Marguerite, moreover, involves him in the representational politics surrounding Marguerite Oswald's public image. In the novel, Marguerite is a composite of the real-world figure, drawn from court and interview transcripts, re-assembled by DeLillo with a careful observance of her idiosyncrasies. The Marguerite whom Stafford presents - neat and tidy, but also self-serving, masculine, and an egotistical opportunist—is the Marguerite Oswald most commonly referenced in popular history. However, as Baldwin suggests, a more complex reading of her reveals inconsistencies and reflects many of the emerging attitudes and positions that would define the women's movement in the 1960s. One of the key aims of feminism, as Nira Yuval-Davis contends, is to lay bare the processes by which national identity is constituted of a manufactured gender difference: "A figure of a woman, often a mother, symbolizes in many cultures the spirit of the collectivity" and simultaneously "embod[ies] the line which signifies the collectivity's boundaries" $(45,46)$. Portrayals of Marguerite Oswald as "masculine" or "aggressive" aim to cast her out as an exile of national womanhood; as a result, she exists in popular culture as a parody of femininity, the anti-mother.

The "small rooms" of Libra, however, highlight the instability of this containment culture, just as the site of the home is both personal and political. Both DeLillo's character and the mother in Stafford's book display what Baldwin calls a "more complex version of the performative...displac[ing] the effort of the nation to create a subject that mirrors its political desire" (93). Baldwin raises questions about the state's posturing toward Oswald, which, like Stafford's interview, attempts to portray her as a deranged citizen and bad mother; this view is compounded by Oswald's declaration that she will clear her son's name by writing her own 
history of the events: "in both Stafford's text and in popular accounts, questions of Oswald's sanity come up the minute she tries to write as a mother" (Baldwin 107). DeLillo, in offering Marguerite a perhaps more sympathetic audience, provides through her a monologic intervention into a historical populism created in part through the state-authored version of the past consumed by the masses at historical sites and in official public documents.

Domestic space throughout Libra, in fact, is far from ideal, determined in large part by a race for material goods and household appliances and a female co-dependency that takes precedence over healthy marital relationships. DeLillo portrays women who suffer at home while the men with whom they have built their lives are absent, scheming ways to intervene in history and become actors in the course of world events. Marguerite's refrain about missing or neglectful husbands is echoed by the other wives, as when Beryl Parmenter, whose husband Larry is one of the co-conspirators of the novel, sits alone watching footage of Oswald's assassination, thinking "these men were in her house with their hats and guns...she felt this violence spilling in, over and over" (446). In the inherent loneliness of this space, the domestic sphere is pierced with the violence of public space, repeated over and over on the television.

DeLillo relies on Marguerite to voice the concerns of a generation of women, who in Libra seek liberation from the containment of domestic servitude. She is, accordingly, like other strong literary mothers, such as the mother in Tillie Olsen's "I Stand Here Ironing" (1961), who writes to critique the expectations placed on mothers in a patriarchal society. Olsen's short story is the first-person defense by a mother accused of neglect in a letter from her daughter Emily's school guidance counselor, who is concerned by Emily's aloofness and morose attitude. There are many similarities between Olsen's Emily and DeLillo's Lee, including the loss of a father early in life, poverty, alienation, and a focused, singular talent (Emily's acting and Lee's talent 
for political debate), and much like Olsen's, Marguerite's story is one in which a mother, overworked and perhaps neglectful out of necessity, explains the tragic consequences of poverty on a family. Claiming she is "not afraid to make food last" (11), Marguerite often bickers with Lee about their condition, arguing, "'I would have given the world to stay home and raise my children...I'm the child of one parent myself. I know the meanness of the situation"” (6). In addition, she continually fights the state of New York and the truant officers who notify her of Lee's absence from school, declaring that " a boy playing hooky in Texas is not a criminal who is put away for study"' (11). In Marguerite's defense of Lee, DeLillo establishes the sociological conditions of his upbringing while simultaneously connecting him to a family history.

Like Olsen's narrator, that defense is directed, ultimately, at the reader. The image of Oswald holding his mail-order rifle on the front cover of Libra begins to take three-dimensional shape with these details, juxtaposed with the larger, more objective story of his life told by the narrator. At the end of the novel, when Marguerite declares, "this is from oldentimes, that the men will kill each other and the women will be left to stand at the grave...but I am not content to stand" (455), she invokes a violent history of patriarchy while issuing a call for women's liberation from the sweep of that history. Interestingly, her commitment to revising the public image of her son coincides with a return to domesticity; as she and Lee's widow Marina are questioned by the FBI shortly after Lee's arrest, for instance, "the babies had diarrhea in their hotel surroundings and there were diapers strung across the room from wall to wall. A president had to die before she could learn she was a grandmother again" (424). Her estrangement from her grandchildren (a result of Lee's insistence that she be kept out of the house) is reversed by Lee's act of violence, and her return to the maternal is punctuated by his loss. 
What happens next proceeds in Libra as in real life: every cemetery in the Fort Worth area rejects Lee's remains, and his brother Robert cannot find a Lutheran minister who will hold services in a church. The real Lee Harvey Oswald's services were conducted by a ministerReverend French — at the last moment, and Rev. French likewise refused church services, only agreeing finally to hold the services at the Rose Hill Cemetery chapel (Bugliosi 314). At Lee's burial in the novel, Marguerite's transformation into bad citizen is completed: as she stands outside the chapel, "holding the new baby in her arms, the granddaughter whose birth they had kept from her," she fumes over the cancellation of Lee's services and the unwillingness of the minister to hold church services, and rejects religion as fraudulent. "The good people do not need to go to church," she argues, "Let's say he is a murderer. It is the murderers who need a church. Isn't this what Jesus teaches?" (448-49). Marguerite, in the end, scorns the two traditional models of authority — state and religious — just as they have scorned her family. Lee's supposed betrayal is met, in Marguerite's opinion, with the country's betrayal of the Oswalds, as Lee's shadow is cast over the entire family.

\section{Speaking for the Dead: Marguerite Oswald and Oral History Performance}

The dramatic persona DeLillo invokes in Marguerite has been treated only superficially by scholars of the novel. She is involved throughout in a distinct type of oral history performance that incorporates a maternal, feminist, working-class, and resistant narrative project to counter the public image of herself and her son. Her testimony represents a direct challenge to institutionalized ways of knowing and to a government that she feels has in some ways betrayed her and Lee. Contrary to Tabbi's opinion that her monologues — spoken to an "unseen judge"contribute to the limited consciousness of the people in "small rooms" that foreground the mystery of the novel, they can instead be interpreted as an invitation to the reader to act in place 
of absent authority. The disembodiment of the "judge" to whom Marguerite speaks in the novel is reconciled by the reader as witness who acts in its place. As oral history, her performance is not always linear, is by definition self-referential, and exists in an out-of-time dimension within the larger narrative, a bridge between the past and present, between history and memory. Marguerite's monologues allow readers to take part in the construction of history and provide an entryway into the complex and convoluted representational strategies employed by DeLillo to reflect the chaotic nature of the history he presents.

The possibility invoked by Marguerite's performance has mostly to do with the recovery of agency in the creation of the history and public memory of her family. Historians are increasingly making a case for the inclusion of oral history into our discussions and representations of the past. ${ }^{9}$ As is especially the case for those marginalized because of their race, gender, ethnicity, or political views, oral history provides an alternative and often necessary means to disseminate stories and preserve communities. Della Pollock, for instance, describes how "the stories told, often deeply expressive of history's burdens, lay claim on us for retelling so that history may be known, shared, perhaps overcome" (Remembering xi). Calling this storytelling "inherently performative" (xi) and an example of "embodied knowing" (3), Pollock argues that oral history performance "has the peculiar temporality of the representational real: an engine embedded in historical time, it invokes the beyond time of possibility" (Remembering 7, emphasis in original). Pollock cites the ways in which the interviewee creates an identity, and indeed, Kevin Connolly, interviewing DeLillo, notes how in the transformation of Marguerite from the Warren Report to the novel DeLillo did "what playwrights often do, taking advantage of the verbal accidents that clipping sentences and colloquialism create" (33). As a result, Marguerite's character is both frustrating and pitiful; she is a demanding woman who insists on 
being heard, a woman simultaneously abused and, in some ways, abusive herself. She is a contradiction created out of the circumstances of everyday life; in short, one feels her presence principally because she is so familiar.

The last lines of the novel serve as the beginning of Marguerite's narrative and as a meditation on the need for private forms of memorialization. Taking place after Lee's funeral, the chapter ends with Marguerite thinking about the name (and legacy) of Lee in a culture of official history: "Lee Harvey Oswald. No matter what happened, how hard they schemed against her, this was the one thing they could not take away — the true and lasting power of his name. It belonged to her now, and to history" (456). If one begins to read Marguerite's story from this point - the end of the novel—her attempts to counter both American mythology and the alreadyemerging portrait of her son become clear. Ironically, however, the "true and lasting power" of the name Lee Harvey Oswald is dependent upon the very mythology Marguerite attempts to expose as fraudulent; the usage of his full given name, for example, situates his remembrance in terms of his criminality and media construction, and not the "Lee Oswald," nor his many aliases, by which he or his mother knew him. The co-opting of personal identity by media culture is something DeLillo treats frequently in his novels; in Mao II, for instance, the media construction of reality leads to the oft-quoted line "the future belongs to crowds." The name Lee Harvey Oswald belongs not just to Marguerite, or to "history," but also to the crowds who stand at the sixth floor window of the Texas Book Depository (now a museum), those who wish to recreate and record for themselves histories and memories previously unavailable to them. ${ }^{10}$

Interestingly, although she attempts to create a linear narrative of her life with Lee, Marguerite characteristically interjects details that stray from her narrative path. As DeLillo reconstructs the adult Lee, Marguerite tells the story of him as a child, and the back-and-forth 
between various stages of his life reflects Marina's observation about Lee in the novel that "the pattern of a life can't be seen in fleeting days or weeks" (286). This subtle characterizationdeveloped more through a comparison between Marguerite's and the novel's narrative arc than by narration itself - mirrors the process by which Marguerite has confounded interviewers in real life. Historian Peter Knight, discussing her hundreds of pages of testimony in the Warren Report, writes that her "testimony is animated by an overwhelming sense of self-importance," in a "lavaflow of accusations and grievances" born out of the frustration of her life. In what he calls a “breathtakingly dogmatic and rude performance," Knight observes how Marguerite—-despite interviewers' constant reminders to stick to the point - "is convinced that she is in effect fighting to clear her son's name" over several days in which her syntax "is as convoluted as her story" and her "story-telling is both exasperating and grimly comic" (60). Knight points to her suggestion, for instance, that Lee should have been given a hero's burial in Arlington National Cemetery along with Kennedy (59-60). She repeatedly ignores requests to keep her remarks brief: "I cannot make it brief, I will say I am unable to make it brief. This is my life and my son's life going down in history. And I want the opportunity to tell the story with documents, as I have been doing. I am not going to answer yes or no, because it is no good" (qtd. in Knight 59-60). The Marguerite Oswald in Libra mirrors this insistence on telling the whole story, which shows a conscious and clever apprehension of historical representation consisting of clear and coherent narratives framed to suit particular motives. Marguerite Oswald offered no such narrative. Her conscious and strategic disruption of her interviewers' formal, processed line of questioning resists the simple cause-and-effect model of historiography, and in Libra Marguerite is similarly a character who acts to limit the narrative capabilities of DeLillo as author in order to keep the novel from overreaching. 
Marguerite interrupts the narrative flow of the novel to tell her story, which begins with her defense of her performance as a mother, both reflecting and revising definitions of the "ideal" mother. She talks throughout about the lack of opportunities afforded them, but also describes in detail how she was able to overcome obstacles, saying, "I am not the looming mother of a bad boy's dreams" (49). She compares their life with that of wealthy families she has worked for: "I have worked in many homes for fine families. I have seen a gentlemen strike a wife in front of me. There is killing in fine homes on occasion" (455). In part, this observation is meant to rule out poverty as a contributing factor to her son's perceived antisocial behavior, even as it contradicts her other attempts to use their poverty to evoke sympathy from others.

Marguerite's narrative is not just the story of a son, but also that of a prideful mother and her desperate attempts to raise a son amidst unemployment and despair. Again, similar to but more defensive than Olsen's voice in "I Stand Here Ironing," the Marguerite Oswald of Libra is answering what she feels is an official judgment of her ability to act as a caring and attentive mother.

\section{Mama's Boy: Countering Marguerite's Defense of Lee}

DeLillo presents alternatives to Marguerite's vision in order to signal his distrust, as a postmodern writer, of any one narrative claim to truth. Although postmodernists frequently champion experiential history as a reactionary mode of resistance to grand narratives, those histories themselves ultimately threaten to become what Dominick LaCapra calls a "hollow shibboleth," or the application of standardized methodology onto supposedly unique formations of identity and other cultural processes (4). Calling identity a "problematic constellation...of subject positions" (5), LaCapra argues that identity is more than just "modes of being," and is also constituted of "the imagined, virtual, sought-after, normatively affirmed, or utopian" (37). 
The utopian vision of American identity that defined the political culture of the Cold War era produced a narrative in which subversion was linked with unstable, violent, and treasonous personality traits. Accordingly, Marguerite's defense of Lee as an American son is crushed by the weight of the "normatively affirmed" identity assumptions of idealized American patriotism during the Cold War. As Donald Pease describes, the American Cold War narrative created a "frame" - bolstered by TV and radio — that situated all events within a narrative of containment and a future of global liberal democracy. In what he calls a normalized "State of Exception" (34), and a "state of fantasy" (94) anchored by an "apocalyptic imagination" (74), the Cold War "enabled US citizens to reexperience everyday doubts, confusion, conflicts, and contradictions" (52). In other words, the sense of urgency caused by fascism during World War II was being repeated in the form of another global threat: communism. ${ }^{11}$ The feeling of accomplishment following Hitler's fall was short-lived, and Americans were again thrust into suspicion and anxiety. As a walking contradiction, Lee Harvey Oswald - the historical figure and the character-became America's scapegoat, the representative figure of the dismantling of American democracy; his "derangement," instead of being a product of inequality, neglect, and perhaps a degree of self-loathing, was claimed to have been the alarming product of subversive thought, the infiltration of communism into America. His story-situated within the narrative described by Pease - emboldened US nationalism in response to an internal threat, and as a result Lee Harvey Oswald's citizenship was symbolically revoked; he remains in limbo as a defector, a man no nation wants to claim.

DeLillo plays within and against this exclusionary narrative in Libra, setting Marguerite's voice against that of the narrator to create a productive tension and reveal Lee's complex inner life. After thirteen-year-old Lee is taken in for truancy, Marguerite tells the judge, "they sent him 
downtown to a building where the nut doctors pick at him twenty-four hours a day" and justifies his behavior by explaining how "this boy slept in my bed out of lack of space until he was nearly eleven and we have lived the two of us in the meanest of small rooms when his brothers were in the orphans' home or the military" (10-11). In a short paragraph after Marguerite's section, DeLillo summarizes the comments of a social worker who studied Lee: “"Questioning elicited the information that he feels almost as if there is a veil between him and other people through which they cannot reach him, but he prefers this veil to remain intact"' (12). The chapter ends with Lee riding the subway, fantasizing about a mad motorman and feeling an "inner power" resulting from the speed, power, and unpredictability of the ride. The contrast between Marguerite's image of her son, his image of himself, and the image determined by interviews with social workers sets up a dynamic that structures much of the novel: while Marguerite defends Lee, and the adolescent and adult Lee constructs multiple, fantastic identities for himself, he is also an object of study for the FBI, KGB, and those who spend the novel planning Kennedy's assassination and Lee's role in the shooting.

These early descriptions of Lee have a humanizing effect as they point to a childhood in which he could find little escape from the isolation forced upon him by poverty and circumstances. DeLillo's Lee was forced to become the man of the household, a stand-in for the husbands Marguerite lost to death and divorce. His alienation was compounded by the treatment he received by the state, which studied him just as he enjoyed to study animals at the zoo. The Lee Oswald DeLillo creates evolves into a young man with delusions of grandeur, most likely caused by his meager surroundings and inability to connect on a meaningful level with others. His seemingly intense privacy — the "veil between himself and others" — is reinforced by his literal confinement in the suffocating space of the home, another type of containment that Lee 
believes is the result of capitalist practices that benefit from economic disparity. At one point, while his mother is browning flour, "he lay near sleep, falling into a reverie, the powerful world of Oswald-hero, guns flashing in the dark. The reverie of control, perfection of rage, perfection of desire, the fantasy of night, rain-slick streets, the heightened shadows of men in dark coats, like men on movie posters" (46). Lee's inner thoughts reflect his frustration with his mother, "always there, watching him, measuring their destiny in her mind." "He had two existences," he thinks, "his own and the one she maintained for him" (47). Passages like these complicate Marguerite's claim to her son's memory. Inasmuch as she serves to contextualize his childhood and to point to clues in his development, DeLillo reveals that no one except Lee knew much at all about him, as everything was veiled in secrecy, a "world inside the world." Additionally, these scenes show how the containment of domestic space, in combination with a growing media culture, made Lee desperate for some sort of escape - either through his own fantasy creation or through the revolutionary literature he would soon encounter.

The familiar refrain "there is a world inside the world" highlights the fantasy world that served as refuge for Lee in the small, cramped rooms he shared with an overbearing and nervous mother. Lee's secret world is defined by his hero-worship for important figures of history, particularly revolutionary and anti-government figures. He recalls how "Stalin's party name was Koba...Police picture, Trotsky, age nineteen. Police picture, Lenin, full face and profile" (47). Lee's secret identity, much like the one fashioned for him by the Bay of Pigs veterans DeLillo creates to map out the conspiracy to kill Kennedy and pin the assassination on Oswald (180), is a conglomeration, a constructed persona brimming with notoriety, revolution, and violence. In the novel, Lee exemplifies what Alek- the KGB agent who handles Lee's defection to Russia after his stint in the military—calls "these people who live in corners inside themselves" (166). Joseph 
Dewey points out how "we have made from unpromising materials a persuasively coherent form named Lee Harvey Oswald," constructed solely from media fragments, which DeLillo counters by returning Oswald to "compelling uncertainties, [giving] depth to the accessible image that the media rendered as history, [re-complicating] history with his story" (93-94, emphasis in original). DeLillo, in his version of Oswald, does not so much claim to present the truth about his life as point out how "there is always another level, another secret, a way in which the heart breeds a deception so mysterious and complex it can only be taken for a deeper kind of truth" (Libra 260). This "deeper kind of truth," instead of a claim of authentic knowledge, refers instead to the patterns and connections established by the currents of history, by the shifts of power and struggles to resist that mark distinct eras. Lee, DeLillo seems to say, did not choose exclusion, but was excluded from the mainstream of American life from the very beginning. A born outcast, Lee sought out those who spoke to this outcast persona, those who could provide him with the direction lacking in his everyday life.

The narrative voice also complicates Marguerite's vision of her son by showing the pair in more private moments that reveal the lack of communication between them. In a basement room in Brooklyn — the only place Marguerite could afford - they are shown watching television, "blue heads [speaking] to them from the TV screen" (4). As she "sat and listened to the boy's complaints" that she is not able to provide all that he wants, the narrator observes how "all her life she'd had to deal with the injustice of these complaints." (4). The reader learns that the father of Lee's brother John Edward left when Marguerite was pregnant because he did not want to support a child; then there was Mr. Ekdahl, who committed "cunning adulteries" that didn't prevent him from "scheming a divorce that cheated her out of a decent settlement" (5). Her private frustrations are employed by DeLillo to suggest that, perhaps, Marguerite Oswald's case against the 
government is not merely about Lee, but about her own inability to achieve the American dream. In Libra, her married last name (she was born Marguerite Claverie) remains her only link to the path of good citizenship that included — for women — marriage, children, and family; when this name becomes symbolic of betrayal and subversion, Marguerite embraces her radical position to fight back against the establishment she feels is responsible for her containment in "small rooms."

\section{Conclusion: "another kind of knowledge": American Myth, Memory, and Narrative}

DeLillo claims that his career as an author, as well as the era in which his work was produced, were shaped in profound ways by Oswald: “"I don't think my books could have been written in the world that existed before the Kennedy assassination"” (Passaro 77). David Cowart explains how DeLillo "seeks to understand his age and his own identity as an artist by returning to and contemplating the act that brought both into being" (91-2). He notes that the Oswald in the novel represents "a kind of strange martyrdom, oddly suggestive of the West's supreme myth of redemptive suffering" (92), and calls the assassination "the moment when the national myth and sense of purpose contracted a strange disease" (95). Kennedy, indeed, takes precedence in the national memory, marked in the novel by Jack Ruby, driving past Dealey Plaza after the assassination, thinking, "this was an event that had the possibility of being bigger in history than Jesus...it was almost as if they were reenacting the crucifixion" (428). The strange disease was something - as it was in Armies and Vineland-lying underneath the surface of American life. The assassination drew back the curtain on the American narrative of progress; it was the boiling over of the tensions that swirl underneath a society plagued by inequality and a shocking revelation about the reality of conditions in America. ${ }^{12}$

DeLillo's search for "another kind of knowledge" - the knowledge in Oswald's eyes as he was shot on national TV and "made us a part of his dying"-posits that we each have a story, 
and that the stories of individuals get lost under the banner of nationalism. These other narratives, such as a mother's about her dead son, are also tinged with fantasy, but they do the necessary work of injecting skepticism into totalizing narratives of experience. These selfconscious national narratives, which Alan Nadel argues join "the legible agenda of American history as aspects of containment culture" (3), subsume individual lives under the rubble of history, which containment culture attempts to pave over, to give the illusion of purpose, of direction, of a clear "road ahead." The emergence of a tangible "postmodern" sensibility in the 1960s, the moment that inspired DeLillo's authorial vision, is symptomatic of the potholes on this road and is evidence that narrative is never smooth, never total, and always political. Libra, at its very center, is an activist text in the sense that it forces one to ask difficult questions about the past and about the ways in which we perceive that past. With Oswald, DeLillo seems to suggest that if we look hard enough at history, and long enough, we will find only ourselves, staring into the future that is the present. It is what we do with this knowledge- whether we seek escape from it or use it as the foundation for a new understanding of self and history — that remains the subject of authors like DeLillo for whom the past is an integral part of each of us. 


\section{Notes}

${ }^{1}$ Two of the most vehement criticisms of the novel came from George Will and Jonathan Yardley in the Washington Post. Will writes, "[Libra] is an act of literary vandalism and bad citizenship...an exercise in blaming America for Oswald's act of derangement” (56). Will goes on to call DeLillo a "bad influence," saying his "left-leaning" politics get in the way of his writing, and concludes, "It is well to be reminded by books like this of the virulence of the loathing some intellectuals feel for American society" ("Shallow Look" 56). Two months before Will's article appeared, Yardley argued that Libra represents the "ideological fiction of the left" and declared, "No doubt Libra will be lavishly praised in those quarters where DeLillo's ostentatiously gloomy view of American life and culture is embraced" (“Appointment in Dallas"). Yardley's take on White Noise, three years earlier, was similar in tone: "he's a writer of stupendous talents, yet he wastes those talents on monotonously apocalyptic novels the essential business of which is to retail the shopworn campus ideology of the '60s and '70s" ("Don DeLillo's American Nightmare").

${ }^{2}$ As Anne McClintock observes, nationalisms are both invented and dangerous, incorporating "historical practices through which social difference is both invented and performed" (89). She describes how nationalism creates identities through "social contests that are frequently violent and always gendered," concluding that the aims of nationalism are "typically identified with the frustrations and aspirations of men," with the nation-state defined not through unity but the through the cementing of gender difference (89).

${ }^{3}$ Anderson's Imagined Communities is relevant to a discussion of Cold War politics and to U.S. nationalism in general, since popular consensus - especially during wartime-is one of the essential qualities of a distinct and united national body. Marguerite Oswald's story thus reveals 
how these imagined communities are shaped by power relations and are a product of both the private "imaginings" of powerful individuals and of a media-influenced popular culture; in the novel, the community's adoption of Marina Oswald (Lee’s widow, a Russian émigré) is a reflection of her fledgling nationalism, whereas its rejection of Marguerite is the result of her attempts to rewrite the narrative of loss associated with Kennedy's assassination. Marina exemplifies what Anderson calls a "blend of popular and official nationalism" (124); her citizenship is defined through her consumption of mass media, her dreams of material wealth, and, officially, her cooperation with state authority in the investigation of her late husband. ${ }^{4}$ I use the term "radical" here to denote Marguerite Oswald's alienation from Cold War Era republican motherhood and also to point to the type of historiography with which she would become involved; her library of materials on the JFK assassination, as well as her defense of her son Lee in an argument that posits the US government as co-conspirator in the assassination, also make her what many would term a radical historian.

${ }^{5}$ The importance of maternal historiography is perhaps best seen in US slave narratives, as the slave mother was a central figure in the fight for abolition. In fact, the success of Harriet Beecher Stowe's Uncle Tom's Cabin (1854) was due in large part to her adherence to the genre of domestic fiction and her melodramatic portrayal of motherhood in the novel. While there is a world of difference between the narratives of enslaved black women and that of the privileged, white Stowe, both could be called, loosely, “domestic fiction," which would apply primarily to narratives about women and motherhood.

${ }^{6}$ George Will has elsewhere betrayed a loathing for sixties counterculture, arguing that the "spirit of the sixties was, strictly speaking, infantile" (The Woven Figure 67). This loathing is also directed, it seems, toward the feminist consciousness that is often associated with the 
decade, as when Will refers to a female biology professor as a "hysteric" because she felt physically ill when Harvard president Larry Summers concluded, during a conference on the Harvard campus, that the disparity in numbers among male and female science faculty was the result of innate cognitive differences (One Man's America 250). "Is this the fruit of feminism?" Will asks, before agreeing with Summers that men are smarter in math and science because of genetic predisposition (One Man's America 251). When combined with Will's (and other conservatives') critique of the political left as concerned with an outdated materialist politics, his anti-counterculture, anti-feminist positioning represents a current of thinking that DeLillo writes against in Libra.

${ }^{7}$ The folk heroes of American westerns, such as John Wayne and Gary Cooper, came in many ways to define masculinity for a generation of Americans who watched their films. They also defined American patriotism through their roles on the screen and in their political activities (both were anti-communists, and Cooper testified in front of the House Un-American Activities Committee in 1947). See Carlton Smith for an excellent resource on postmodern literature and frontier mythology. Also see McMahon and Csaki.

${ }^{8}$ See Stafford.

${ }^{9}$ See, for example, Hamilton and Shopes; Prins; Vansina; and, for the importance of oral traditions to women's and ethnic minority's histories, see Kleinberg; Fabre and O'Meally. ${ }^{10}$ An example of a place where past and present, history and memory, and authenticity and imagination converge to create interesting personal and cultural confluences is the Sixth Floor museum in the Texas School Book Depository at Dealey Plaza. The Dealey Plaza museum is distinct in that it privileges the perspective not of the victim (Kennedy), or of the crowd, but of Oswald, thus feeding off a culture obsessed with violent death and with the figures responsible 
for it. Seeing Dealey Plaza from Oswald's point of view offers an unsettling entryway into the national narrative of Kennedy's assassination that has gone underrepresented in discussions of the event, especially since the legacy of the assassination is largely constructed from a detached, third-person perspective.

${ }^{11}$ Many have argued that the beginning of the twenty-first century marked another era of global crisis in the form of Islamic terrorism, which has led to the re-iteration of many of the same types of containment narratives that undermined the rights of US citizens during WWII and the Cold War.

${ }^{12}$ Malcolm X, in 1963, famously noted how even those Americans "blinded by childlike patriotism" (121) can see how "the chickens are coming home to roost" ("The End"). 


\section{Chapter Four:}

\section{Buddhist Historiography: Mindfulness and Civil Rights in Charles Johnson's Dreamer}

Similar to DeLillo's Libra, Charles Johnson's Dreamer (1998), about the life and death of Martin Luther King, fictionalizes a real-life figure in order to frame a "new kind of knowledge," in this case concerning the civil rights movement. The African American civil rights movement ${ }^{1}$ has produced, in popular culture, a fantastic and triumphant narrative of resistance, with certain figures and events-King and the 1963 March on Washington, Rosa Parks and the Montgomery Bus Boycott, the Birmingham church bombing, the Black Panther Party for Self-Defense (and Black Power, generally) — taking precedence in the national mythology. The permanent exhibits at the National Civil Rights Museum at the Lorraine Motel in Memphis consist of a timeline of key events in civil rights history, covering the entirety of African American slavery in one display and ending, presumably, with King's final hours at the hotel. King dominates the museum's presentation of African American freedom struggles, just as he commands the national consciousness in relation to civil rights. ${ }^{2}$ Dreamer is one of many recent efforts — along with work by black intellectuals such as Michael Eric Dyson, Houston Baker, and Cornel West - to rework this narrative and to add depth to a characteristically thin presentation of civil rights history in popular culture. The disagreements over how to remember King, especially in African American scholarly communities, point to the importance of historical narratives in fashioning group identity and in establishing authoritative cultural scripts. ${ }^{3}$

In creating grand narratives of history (mostly to fit a larger framework of national mythology), museums and other authors of historical narrative present selective interpretations of the past. This selectivity is strategic; David Lowenthal, for instance, observes how historical 
relativism makes any "golden age an evident fiction" and how, currently, "we hanker less for a golden age...than for the past in general or for more recent if less inspiring Good Old Days" (372). By highlighting specific moments in a "particular past," popular historical narratives actively construct these "Good Old Days" and induce nostalgia for a past that is itself a fantasy produced through selective amnesia. The violent history of the civil rights movement is thus sometimes overshadowed by presentations that paint it as a triumphant spectacle of feel-good speeches and inspirational martyrdom, what Edward Morgan calls a "consumable past": "The horrors of racial oppression occurred in the South. They were erased when civil rights activists appealed to the national consciousness and the government to override the peculiar institutions of Jim Crow. The federal government played the crucial role in righting these wrongs, thus removing America's great hypocrisy" (153). The erasure Morgan writes about is accomplished through the marginalization of radical voices and, in the case of King, an active forgetting of his more radical ideas.

As a postmodern writer, Johnson often resists the illusion of narrative consistency and completeness by characterizing history as a palimpsest, with the sum of the various layers reflecting an elusive and perhaps unreachable totality. As in his National Book Award-winning Middle Passage (1990), acknowledging this conflation of past, present, and future in Dreamer results in spiritual growth and an awakening of historical and ethical consciousness. Postmodern historiography provides Johnson with a framework within which to articulate an alternative history of the civil rights movement and of King's particular place within it. However, Johnson's postmodernism does not simply signal the end of narrative authority; instead, it uncovers the possibilities inherent in narrative freedom while resisting the characteristic cynicism of postmodern thought. ${ }^{4}$ Stuart Hall argues that postmodernism is simply "the current name we give 
to how those old certainties began to crumble," and prefers instead a "theory of articulation" which "enables us to think how an ideology empowers people, enabling them to begin to make some sense or intelligibility of their historical situation" $(47,53)$. Similarly, Linda Hutcheon locates the "ideological formation" of postmodernism in 1960s social, political, and artistic movements, but concludes that it "never offers answers that are anything but provisional and contextually determined (and limited)" ( 8, xi). Thus, while postmodernism rightly challenges authority and works to de-centralize knowledge, the ironic distancing it often implicitly proposes as an alternative is unsuitable to any sort of sustainable or practical epistemology. Satya Mohanty, too, understands the consequences of postmodern detachment in the disintegration of a society's methodological and moral "scruples": "relativism blurs the outlines of [the social] world, substituting a hazy vision of cultural equality for accurate knowledge and genuine engagement" (148). The cultural pluralism championed by postmodernism, in other words, inhibits the development of shared cultural beliefs and practices in favor of irony, parody, and skepticism, while at the same time producing endless counternarratives and metadiscourse on the nature (and limits) of representation.

The "new kind of knowledge" presented in Dreamer is, moreover, derived from an application of Buddhist principles to historiography and to African American culture. Johnson reverses the impulse toward cultural deconstruction by merging the sacred and the secular in Dreamer, ultimately characterizing African American history and the history of the civil rights movement as part of an ongoing quest for a spiritual community. King's interest in Buddhism toward the end of his life allows Johnson to highlight King's evolving philosophy of nonviolence - that of an inward peace projected outwardly — and also to reveal the spiritual crisis at the heart of America. Mindfulness, in Buddhism the state of being awake to the present 
moment, and the precursor to acceptance and enlightenment, is in the novel prohibited by the dream state within which the masses reside. Johnson invokes Buddhist philosophy in Dreamer to situate the civil rights movement within a larger patchwork of African American history, while the meditative spirit of the novel urges one to conceptualize "official" history as the imposition of the ego on the past. ${ }^{5}$ Ultimately, Dreamer calls us to see "history" as an attempt to dream in the past, as a willful rejection of the immediate present, while the dream of integration and equal rights is pushed forever into an endless future. In order to underscore the Buddhist tendencies of the novel, ${ }^{6}$ I discuss Dreamer in relation to the "three marks of existence" of Buddhism: Dukkha (suffering), Anicca (change or impermanence), and Anatta (non-self). These "three marks" aid in understanding the African American experience in the US and provide a framework (a necessarily limited one, to be sure) for approaching African American historiography, which characteristically situates slavery and racism (suffering) within a narrative of resistance (change)

and survival (non-self/beloved community) in a white supremacist nation. ${ }^{7}$ Johnson's application of Buddhism to civil rights movement history also promotes a revolution-within-the-self that must be accomplished before any sustainable models of activism can be practiced. Dreamer begs to be considered as a participatory text in the way it encourages readers to carry King's voice and message forward in establishing "beloved communities" devoted to social progress.

\section{Dukkha: Martin Luther King and the Nature of Suffering}

Also like Libra, Johnson's novel consists of complementary narratives that intersect and combine at strategic points in the story. The effect in both novels is to give the reader choices; true to postmodern style, the multiple perspectives in each point to different versions of history or of "truth." Alternately, they allow readers more choices in terms of the empathic connections DeLillo and Johnson attempt to create through their prose. In Dreamer, the first narrative is a 
disjointed series of chapters written in italics, ${ }^{8}$ a third-person view of King's deteriorating faith in the movement and himself, and his questioning of God, human nature, and the willingness of people to transcend selfishness and evil to cultivate love. These chapters show King's attempts to awaken spiritual love in America and document his own gradual awakening to the permanence of suffering in a world shaped by dreams of power and supremacy. Beginning in a tenement in Chicago where King stayed during his fight for equal housing for Chicago's black population, this narrative proceeds to the later stages of King's career as civil rights leader, touching on the Chicago campaign (13-20); the Montgomery bus boycotts and subsequent death threats (78-80); his life at home with his family, including harassment from the FBI and rumors of adultery (18696); and a conversation with Ralph Abernathy following the riotous Memphis sanitation march in March 1968 (215-225).

It is evident in these chapters that Johnson's main concern is to establish King's inevitable downfall in the months before his assassination. Throughout, King thinks about death, and about how it might even come at the hands of his own people. ${ }^{9}$ Johnson's King reflects on his perceived failures and his inability to convert the masses to nonviolence, worrying constantly that Black Power-with its seductive call to revolutionary violence —will supplant him as the public face of the civil rights movement. He also questions the nature of the universe and the existence of divine justice after meeting a man who mirrors him in looks and in natural talent and intellect, but who has led a life full of suffering and disappointment.

This man, Chaym Smith, is the primary subject of the intervening chapters, as two student volunteers for the Southern Christian Leadership Conference-Matthew Bishop and Amy Griffith — train him in a remote Illinois farmhouse (owned by Amy's grandmother, Mama Pearl) to emulate King's oratory so he can serve as King's double and, presumably, keep him out 
of harm's way. Smith is resistant to King's message in the early stages of the novel; he is a world-wandering veteran of the Korean war whose dense spiritual and religious background (he studied at a Zen temple in Japan after the war), combined with what he feels is a global racism toward Blacks, has led him to an introverted cynicism that borders on nihilism. Toward the end of the text, however, he takes a bullet meant for King and undergoes a spiritual transformation/re-awakening just as FBI agents intercede to "ask" for his help in ousting King from power.

Bishop supplies narration in these chapters; a bookish, part-time philosophy student in love with Amy, he undergoes his own transformation at the hands of Smith, who counters Bishop's naïveté by challenging him to confront the contradictions and shortcomings of his optimistic worldview. These two narrative threads intersect at moments of doubt and violence, but also at moments of transcendence--such as when Smith watches in awestruck admiration as King delivers a powerful sermon to a small black church upon receiving an award. Overall, the fragmented style in which the story is told comments on the experiential knowledge that official or public history often either avoids or idealizes, ultimately revealing the chaotic and disordered nature of human experience and memory. Again, it is the interiority of the movement that Johnson hopes to capture, as Mailer did with the March on the Pentagon, Pynchon with the counterculture, and DeLillo with the Oswalds. This "felt" history is important in establishing the kinds of contacts between past and present that these authors wish to create and to shaping the historical narrative into which readers enter.

No memory of King is more prominent than his "I Have a Dream" speech, delivered at the Lincoln Memorial in 1963 as part of the March on Washington. ${ }^{10}$ Johnson's critique of the dream state in the novel, however, leads to an interesting possibility: King's speech, the hallmark 
of the civil rights movement in popular memory, contributed significantly to his downfall and symbolically pushed the realization of equal rights into a distant, imagined future. Malcolm X's warning to white America in that same year to "wake up and take heed" (128), in addition to his characteristic themes of a "sleeping" black America that would "wake up" and convert to Islam, were seemingly in direct confrontation with King's dream of integration, and this split, for Johnson, was the beginning of the end for King and the movement. All sides of the African American struggle for rights in the 1960s believed, essentially, the same thing, as stated in Dreamer: "since the Civil War black people could never be at peace in the present, comfortable with the past, and were waiting, always waiting, for a day of redemption that forever receded like the horizon" (63). Accordingly, King's image and message, as co-opted by white America, made him a target for some African Americans who wanted equality immediately, who equated his dream with inaction and viewed his cooperation with white officials with distrust.

The aim of the civil rights movement was, in King's mind, to integrate all of humanity into a spiritual project geared towards human rights. Indeed, many scholars have commented on Johnson's integration of social, political, and spiritual life by relying on Buddhist principles. John Whalen-Bridge claims that Johnson offers a "Buddhist revision of the Genesis story" (513) that implicates a post-1960s generation guilty of a "failure to honor unity more than division" and who are "responsible for the "death of Abel" (515). He says that Johnson "boldly reinterprets King's life in recognizably Buddhist terms," while the "Buddhist-Christian dialogue in the novel metaphorically represents...Johnson's poetics of integration" (518). Gary Storhoff observes how Dreamer's "central symbol, the dream, is for Johnson double-edged. It signifies both the JudeoChristian dream of a more harmonious society... and a Buddhist understanding of the world itself as an illusory dream" (Understanding 184). While both Whalen-Bridge and Storhoff successfully 
apply Buddhist thought to the text, they do not adequately explore how the dream state of the novel was an active political construct resulting from a tradition of white supremacy in the US. The rhetoric of dreaming is itself comprised of a duality; King's "dream" of integration was used a political weapon by both whites and radical blacks to shape the public image of King to suit their interests, to contain African Americans on the margins of national consciousness and political discourse.

Dreamer recasts the image of King as an "Uncle Tom" by focusing on the last years of his life, in which he became increasingly frustrated with nonviolence as a tenable philosophy for the masses and more understanding of radical thought. ${ }^{11}$ He doubts the capacity of humanity to forgive and to release the debilitating hold of the ego - to King the impediment keeping racial tolerance from becoming reality. Early in the novel, Johnson establishes King as the "heir of Thoreau" (14), a spiritual guide for North America, and has him declare social distinctions "ephemeral garments" that are part of "the self's baggage" (17). Considering the racial politics and the dynamics of power in 1960s America, King decides it "is little wonder, then, that so few grasped the goal he pointed to" (17). It is clear, from the beginning, that this goal is not just one of racial integration, but of an integration of a national and, more importantly, human spirit. "Every social evil he could think of," King decides, "arose from that mysterious dichotomy inscribed at the heart of things: self and other...it was a schism that, if not healed, would consume the entire world" (18). In other words, difference does not originate from without, but starts within the individual, and the recognition of that difference allows the ego to develop in relation to an other. Seeing others as separate, as unconnected to the individual self, leads to the adoption of identities opposed to those outside of the self and necessarily in contradiction to them. 
King's own identity crisis in Dreamer is compounded when he meets his other, Smith, who is the mirror image of King physically, but who is in a spiritual crisis. Bishop first introduces Smith to King in Chicago, and King looks at Smith as if "peering into a mirror, one in which his history was turned upside down" (32). Smith wore a shirt "torn in at least two places," pants that were "splotchy with indecipherable stains and threadbare at the knees," and was "the kind of Negro the Movement had for years kept away from the world's cameras: sullen, ill-kept, the very embodiment of the blues" (33). Smith relates how he had been sent to Korea (in 1949 or 1950, presumably) and had been seriously injured after stepping on a landmine. He wandered around Japan, Indonesia, and Burma before returning to the States with plans to become a preacher; instead, working as a custodian, he met a woman named Juanita, a single mother with three small children, and eventually married her. One night, a despondent Smith walks aimlessly around Chicago and ends up at the police station, suffering from exhaustion, and is held after police discover Juanita and the children brutally murdered (although there is nothing to connect Smith to the crime). When he meets King, Smith has recently been released from the state mental hospital at Elgin and implores King to let him be his double, to attract the violence meant for King, who was the victim of a failed assassination attempt in $1958 .{ }^{12}$ Although reluctant at first, King finally acquiesces; after Smith leaves, King lies awake, disturbed by the encounter and his resemblance to a man seemingly so different from himself.

Smith, however, is not simply a doppelganger; he is, to some degree, the physical embodiment of both the American promise and the "dream deferred," a volatile mixture of hope, cynicism, self-loathing, and revolutionary discontent. King questions his own beliefs after their meeting, during which Smith discounts the notion of equality as a transcendent, natural state conceived by God. King begins to wonder if equality, the cornerstone of his personal faith and 
his approach to the movement, was "no more than a word, an abstraction, empty sound signifying nothing" (45). Calling the questionable promise of equality the "chimera at the Movement's core," King ponders how he and Smith are like "negatives of each other," and curses "the arbitrariness of fortune" (47). These intimate moments point to a bitterness in King, an awareness that suffering — which in Buddhism is synonymous with life itself-is in fact not equal, that some people (those with dark skin) have historically been made to suffer more than others. This realization shakes his belief in divine justice and exposes something within him that he had been fighting all throughout his ministry: doubt.

The crisis introduced when King meets Smith forms a larger thematic purpose in the novel, which is to pit postmodern cynicism against a Buddhist notion of dharma—or the "state of radical freedom" (Johnson, Turning the Wheel, 14). Both, in their own way, require one to be awake, and Nietzsche's pronouncement that "God is dead" seems particularly suitable to postmodern pronouncements concerning the demise of master narratives. ${ }^{13}$ Smith symbolizes this refusal of the divine order in the novel by refuting King's message of equality, the difference being that God's death in Dreamer is analogous to the spiritual death of America, the refusal of a nation founded on Christian beliefs to recognize its own blatant denial of equality to non-whites. Because of his experiences in Korea (such as seeing Korean soldiers place the severed heads of two American soldiers—one white, one black—on the opposite body as a joke), Smith espouses a very Nietzschean reading of scripture: "it showed me there's two kinds of people in this world. Predators and prey. Lions and lunch...if you'd been through half of what I have, you'd put that Bible away and learn what time it is, or learn how to read it right" (55 emphasis in original). Smith's admonition to "read it right," especially in the context of the rioting surrounding them in Chicago, speaks to a revolutionary world (and Biblical) history; African Americans, he seems to 
say, have been lunch for too long, with white America feeding off the labor and death of centuries of blacks in America. James Baldwin, in The Fire Next Time (1963), articulated the position of many disillusioned blacks: "The Negroes of this country may never be able to rise to power, but they are very well placed indeed to precipitate chaos and ring down the curtain on the American dream" (88). ${ }^{14}$ The riotous presence of African American anger in streets throughout the US in the 1960s was evidence of Baldwin's assertion, and King's vision of equality ran up against centuries of broken, unfulfilled promises.

In Dreamer, Memphis is the crucible in which the gathering force of self-doubt and violence in King's world reaches its melting point. In this section, King sits with his aid and closest friend Ralph Abernathy in a hotel room after the disastrous 1968 march for the Memphis sanitation worker's strike, during which a contingent of young people holding "black power" signs erupted in violence, looting stores and clashing with police. After sending Abernathy to distract reporters outside, King vomits and begins sobbing, thinking that lately he'd "wept often and easily...trailing tears across a continent" (217). In his mission to link race with poverty-the Poor People's Campaign—King recalls how he'd interviewed black tenant workers, and "in their tin-roofed shacks he saw barefoot children, their stomachs bloated, wearing clothes woven from dirt: babies living in conditions as miserable as those of the Untouchables in India" (217). The real Martin Luther King's determined involvement of poor blacks in his campaigns toward the end of his life brought him face to face with "the kind of Negro the Movement had for years kept away from the world's cameras" (33). They were also his primary source of inspiration in the novel, as the sanitation workers he worked with in Memphis uplifted him with their "hope and dreams of dignity" (221), similar to what Richard Wright in 12 Million Black Voices called the "uneasily tied knot of pain and hope" characteristic of African American experience (11). 
This knot begins to unravel in Memphis, as King's despair reaches its climax and Johnson links King's spiritual demise with his physical death. After the march, King tells Abernathy that they should "get out of the way" and let all of the competing factions "go at each other in a full-scale war" (223). Arguing that "hate is too easy," King says, "let them kill each other and tear it all down, then God-hungry men and women can make a fresh start" (223). As he falls asleep, King then starts to think about the Buddhist concept of "Maya - the world as itself a cradle-to-crypt dream, in which all men were caught and only the blessed allowed to awaken" (224). Shortly afterward he begins to make plans to go home and prepare for a second trip to Memphis for another demonstration and "for himself, a fuller, deeper, and more perfectly realized broken heart" (225). At this point in the novel, King has experienced a series of spiritual crises, if not a death of sorts in his realization that nonviolence is an unsustainable practice. His murder/assassination a page later ("a prophet had fallen") is thus the physical manifestation of his (and America's) spiritual paralysis, as well as a comment on the historical inevitability of martyrdom. As Bishop explains at King's funeral, "we'd killed him—all of us, black and white - because we didn't listen when he was alive," and because "exalting the ethnic ego proved far less challenging than King's belief in the beloved community" (235). Bishop's thoughts end with him comparing King's murder to an act of national suicide, deciding that the collective spirit of the era - which fed off of hate and violence to far greater degree than lovewas ultimately just as responsible for King's death as the bullet that tore through him.

\section{Anicca: Impermanence and the Path to Spiritual Rebirth in Dreamer}

Audre Lorde has said that "one of the most basic Black survival skills is the ability to change, to metabolize experience, good or ill, into something that is useful, lasting, effective" (135). Indeed, the central conflict in Dreamer has to do with change; the need for change in 
order to ensure the survival of black communities and the unwillingness of many white people to allow for that change. For white America, change is to be feared as something that undermines the historical dominance (social, economic, political) they have enjoyed and which has perpetuated the myth of white supremacy throughout generations. Johnson suggests in Dreamer that this acknowledgment of impermanence makes Buddhism an appropriate lens through which to view and critique black experience. In many ways, black people have not had the luxury of dreaming; mindfulness, in Buddhist thought something that is cultivated throughout a person's lifetime, is for black people a means of survival.

In the novel, Johnson positions Smith to inject Eastern philosophy into the spiritual element of the civil rights movement, which is often associated predominantly with the largely Christian social gospel of King. Whalen-Bridge offers the most comprehensive analysis of Smith, citing the importance of Johnson's fusion of Judeo-Christian and Buddhist principles through the dualism of King and Smith, the latter of which he recognizes as a 1960s character type: "We slight Johnson's achievement as a literary integrationist if we fail to see that by reincarnating the dharma bum within the Civil Rights Movement he has imaginatively integrated the largely white male Beat tradition in American literature" (511). Whalen-Bridge identifies Smith as the "dharma bum" of the novel, an example of "America's postwar trickster" that "plays havoc with supposedly firm lines of identity at every opportunity" (512). However, this reference to the Beats - and Jack Kerouac in particular — has the effect of creating a target for Whalen-Bridge to elevate Johnson: "the connection between antinomian freedom and the painful side of drugs and criminality is explored more responsibly [in Dreamer] than in much Beat literature of this period" (512). My own analysis of Smith differs from that of Whalen-Bridge, who sees Smith as a sort of "Zen hero" (512); not only is Smith's faith or spirituality in question 
throughout much of the novel, positing him as an extension of the "dharma bum" makes him a product of both a white literary tradition and a white author (Kerouac) who was criticized for creating what many saw as a depthless Buddhism in Dharma Bums (1958). ${ }^{15}$ Smith is not of the Beat generation in Dreamer; as "the embodiment of the blues," he is instead part of a post-war generation of African Americans who embrace the underlying cynicism with which blacks have historically viewed American politics. ${ }^{16}$

Despite Bishop's own turn toward pessimism at the end of Dreamer, Johnson does reserve the possibility for individual growth and transformation. At a critical point in the novel, while Smith is recovering from the gunshot meant for King (a moment I discuss below), Smith tells Bishop, "Ain’t no two people on this planet got the same fuckin' dharma" (160). Bishopwho along with Smith is renovating a tattered black church in Jackson County, Illinois (where they had been staying at Mama Pearl's farmhouse) — has just told Smith he is going after Amy, who returned to Chicago after deciding she did not have the strength to continue working for the movement. The callousness of Smith's response to Bishop trivializes what is actually one of the fundamental guiding principles of the novel: that individuals approach wakefulness on their own terms, in their own time. In Buddhist thought, existence is marked by tension; the pull of an imagined reality, the dream-state of the self as separate, the drama of the world, keeps one from realizing the world (and oneself) as an already perfect manifestation of a universal order. An individual's dharma, in C's remark to Bishop, is merely the path the individual takes to achieve this realization. The central tension in American history, accordingly, is identified as the inability (or, more accurately, unwillingness) of whites to include people of color on the path of liberation articulated in the Declaration of Independence. 
Dreamer thus makes a distinction between a universalized spirit— the idea that everyone is part of the same elemental energy — and a national consciousness that is determined historically by a largely white supremacist worldview. King sought the manipulation of that consciousness into one unfettered by exclusionary socioeconomic policies and entrenched identity politics (relating to the ego); however, Smith's conclusion that dharma-interpreted here as the path of the individual to spiritual awakening — runs against the current of popular consensus or mass opinion obviates the creation of a tenable social-spiritual movement aimed at recasting traditional, entrenched power dynamics. As in Johnson's Oxherding Tale, the world-atlarge remains relatively unchanged in Dreamer, while individual characters are used to convey the significance and possibility of inward change. Johnson's characters are typically marked by duality: Oxherding Tale's Andrew Hawkins is the biracial offspring of a slave and a plantation mistress, while Smith is a would-be Christian minister turned Buddhist. In Dreamer, the personal trajectories of Smith and Bishop — like that of King — exemplify both the limits and the necessity of this change in terms of self-realization and understanding.

From the very beginning of their journey together, the paths of Smith and Bishop seemed destined to converge, and again Wright's image of the "knot" is instructive in thinking about the duality of experience the two invoke. One (Bishop) is the idealistic dreamer, the prototype of a student volunteer of the SCLC, a true believer; the other (Smith) is the antithesis of the movement —a selfish, cynical misanthrope whose self-defeating nature is capable of bringing down the movement from inside and who represents the "oblique angle of alienation" in the novel (85). On their way to Mama Pearl's house, Smith tells Bishop, "you got to remember that nobody on earth likes Negroes. Not even Negroes. We're outcasts. And outcasts can't never create a community" (65). Smith's defeatist attitude—as well as his anger-starts to affect 
Bishop as they journey outward from the movement's center (at that point, Chicago). Smith talks repeatedly about "saving" Bishop from mediocrity, from "fitting in and mumbling the party line" and claims that he can help him become an individual; shortly thereafter, when they stop at a roadside diner and are confronted once again with the comfortable racism of even poor whites (in the figure of Arlene, the lone waitress, and an old man who is the only other customer), Bishop begins to absorb some of the hate preached by Smith. When Arlene-who hesitantly agreed to serve them-ignores Bishop's outstretched hand and places his change on the counter, Smith's anger emerges in Bishop, and Bishop reacts violently by trashing the diner: "I threw the food in her face...screaming so loud and long my glasses steamed” (73). Smith, following Bishop out to the car, grins and tells him "with a li'l more work, you gonna love it where I live" (74, emphasis in original). The emphasis placed on the "I" has double meaning in the above passage, as it highlights the differences between Bishop and Smith (and the complexity of African American experience) as well as underscores the emergence of Bishop's ego-the "I" symbolizing Bishop's momentary loss of control to the urges lurking underneath his obedience to King's message of selflessness.

As Johnson makes clear later in the novel, Smith's recognition of the "emptiness" at the center of things is itself an act, a mask that hides or refuses to come to terms with his traumatic past and the rage feeding his ironic self-distancing. Smith refuses to commit to anything, using Eastern philosophy as a crutch to argue for the meaninglessness of ordinary human events; accordingly, after Amy tells the story of her family, the Griffiths, and the significant AfricanAmerican history of the town, Smith abruptly declares, "I need to shit," and when Amy hands him an SCLC commitment blank to sign, he heads to the outhouse, telling Bishop, "tell her thanks for this. I need something to wipe with" (92-3). Smith's response is shaped by his past 
experiences; he finds little hope for solidarity in a world in which, as he previously explained, even blacks hated other blacks. Since the very notion of American citizenship, as well as full access to the rights and privileges of citizenship, has historically been predicated on and defined by an individual's whiteness, African Americans (in Smith's view) would always be African first, American second. ${ }^{17}$ Whites, in other words, would never open the doors of full citizenship to anyone other than themselves, meaning that the gains of the civil rights movement would be symbolic victories that would do little to change the living conditions of black people in America.

Johnson, however, positions Smith's scatalogical response to Amy's story and the SCLC pledge as a critique against postmodern cynicism and its characteristic celebration of detachment. As Bishop hurls rocks against the outhouse, Inside, Smith laughed...and kept on talking through the door, railing against conformity and convention, all the while emptying his bowels loudly, with trumpeting flatulence and gurgling sounds and a stink so mephitic it made me choke (93).

Bishop's conscious use of the word "mephitic" to describe the stench of Smith's waste is telling because it implies a smell that is both disgusting and poisonous. Smith's poisonous bowels reflect the fermentation of his postmodern condition; the result of irony and cynicism, Johnson appears to say here, is self-pollution, the rot of a worldview ultimately as untenable as the wholesale practice of nonviolence. This recognition of the insufficiency of postructural/postmodern theories to provide a basis for sustainable communities is echoed by those such as Marshall Gregory, who insists, "nothing is more suggestive of the inadequacy of anyone's theories than that fact that the propounders of them cannot live by them" (54). Gregory 
claims that conceptions of "morality" or "ethics" are fundamental to existence, and thus survive the attempts of "epistemological relativism" to refute the existence of intrinsic value: "Every choice we make in life is both a reflection of the self we are and a creation of the self we are becoming....We are not selves just passively molded or shaped by cookie-cutter forces of language or history" (54-55). This analysis is confirmed in Dreamer; Smith's spiritual crisis is partly a result of his aggressive detachment from humanity, and his self-serving misinterpretation of Hindu and Buddhist teachings as justification for this withdrawal is a symptom of the underlying illness in his soul.

Ironically, it is through an act of violence that Smith begins his journey toward healing. When a march in Chicago turns violent and Smith is used as a decoy to lure a mob of angry whites away from King, King — convinced of Smith's ability to double him—asks Bishop to have Smith accept an award for him later that night at Calvary AME church in the suburb of Evanston. When King shows up at the last minute to give the speech Smith was supposed to give in his place, Smith is transformed. He experiences something akin to a baptism while listening to King, and is spellbound when Bishop finds him watching from the shadows behind the pulpit. Bishop narrates: "to me it seemed King's double was undergoing a kind of living death... almost as if he was ashamed of - and despised — his own being." "'How does he do that?"” Smith asks, “"His voice...It feels when he's preaching like his words come from inside me, not outside—like he gives my soul a voice"” (142). Outside the church, as Bishop and Amy prepare to drive Smith back to the farmhouse, Smith urges them to give a ride to an old, disheveled black man who wants to talk to "King." Upon exiting the vehicle, the man-whose wife had run away with a minister - pulls out a gun and empties it into the backseat after telling Smith (King), "Ministers like you are responsible for all my troubles" (146). In the ensuing chaos, Smith refuses to be seen 
by a doctor, so he is driven to the farmhouse to recover from the single bullet wound in his side; the shooting, along with the condition of the house (which has been ransacked by the FBI in their absence), is too much for Amy, who returns to Chicago, leaving Bishop to tend to Smith.

More important than his physical recovery is Smith's emotional turnaround, which immerses him in the idea of black community he has rejected. On their way back from taking Amy to the train station, Smith asks Bishop to stop at the small, run-down Bethel AME church, and although Smith tells Bethel's Reverend Littlewood that he is not a Christian, Smith chooses the church as his sanctuary, a place to retreat from the world as he heals. In a sort of symbolic return, Smith sits through a sermon in which Rev. Littlewood discusses Genesis and the story of Cain and Abel. The reverend asks, "'How can God be just if He rejected one brother's gifts and exalted another?"” and answers that God does not reject Cain, but asks, "“if thou does well, shalt thou not be accepted?'" (157, emphasis in original). Scholarship on Dreamer often privileges the symbolism of the Cain and Abel story in its application to the Smith/King dynamic, but in some ways Reverend Littlewood's focus on how to define "doing well" is just as important to understanding the novel. Rev. Littlewood says the divine advice is remarkable not for its mysterious meaning, but for "the quality of sacrifice and sentience" it invokes (157). Sentience is exactly what Smith flees from throughout the novel; he resists the urge to feel, the pull to connect with others, until King's speech and the piercing of his outer shell by an old man's bullet induce him to return from a self-imposed exile. Smith realizes, just as King preaches, that "doing well" means to position yourself in relation to others and to see not the individual self, but the communal self that links all humanity to a larger chain or spirit of being.

Smith's toxic spirit is cleansed through hard, manual labor and through the recognition that pain, like all of existence, is temporary. After the sermon, Smith volunteers himself and 
Bishop to restore the church by clearing the town cemetery, improving the landscaping, and remodeling the inside of the church. Bishop relates how he and Smith worked from dawn to dusk, with Bishop "perspiring so hard you could tell where I'd been standing because there I left a puddle, like some of me had melted away" (160). Bishop decides this is too much work and leaves town to track down Amy, about whom he has been obsessing since her departure. Smith, however, works on and even begins to teach a Sunday school class, acting out biblical tales for the children and directing them in their own plays. He explains to Bishop-who returns when Amy grows worried about Smith - that his work at the church has not converted him, but that the work itself, and the chance to make people happy, is enough. He is, accordingly, also the symbolic double of another in the novel: Robert Jackson, the carpenter responsible for building much of the infrastructure of black Evanston, a suburb of Chicago.

Smith's transformation is interrupted, however, by what might be termed the anti-civil rights movement, or the efforts by a racist FBI to disrupt black liberation struggles. Upon returning to the farmhouse Smith and Bishop are confronted by the two FBI agents who have been watching them ever since Smith's and King's first meeting; threatening to bring charges against Smith for past misdeeds, they blackmail him into a scheme to disgrace King and force his retirement. They list all the reasons why King is failing: his outspoken stance against the war in Vietnam, his ego, his paranoia, a "messiah complex," his lack of talent for organization, the splintering of the movement into various factions, his apparent sympathetic stance towards Communism, and what they identify as a long-standing death wish in his tireless pursuit of his goals (198-203). The agents — symbolic of white power — are employed by Johnson as guardians of the dream of white supremacy, those who don't want America to wake up, who desire to keep 
equality just beyond the grasp of black America, to uphold the promise of the American dream but not the substance.

\section{Sangha: African American History and the Beloved Community}

Dreamer presents African American history through a Buddhist notion of community that transcends the narrative of black people primarily as victims. The central concerns of Buddhism - the dream-state of reality, the nature of suffering (especially as compounded by the ego), and the interconnectedness of being and the world - provide a useful framework within which to discuss African American history and historiography, especially since approaches to that history have typically combined sacred and secular understandings of black experience. According to John Ernest, nineteenth-century African American historians were involved not in writing a coherent narrative of black people in America, but in creating a "story of disruptions, of fragmentation, so as to identify the contours of a story beyond the reach of representation" (9). Ernest calls this a "performative historiographical mode that supports the shifting performance of individual and collective African American identity" and argues that "the collective experience of oppression shaped a collective moral identity that allowed African Americans to identify themselves both historically and theologically" $(9,10)$. This "collective moral identity" is arguably understood best in relation to what Ralph Ellison called the "ethical schizophrenia" of a white America that espoused freedom so eloquently and yet withheld it so brutally from thoseenslaved blacks — whose labor made the rapid growth of the nation possible (99). The collective moral identity of African Americans, then, was born out of the refusal of the nation to recognize black subjectivity; the suppression of the individual black ego resulting from the conditions of slavery contributed a great deal to the establishment of strong communal ties between black people founded on a shared vision of freedom. 
Johnson shows in the novel how Buddhist thought can reveal patterns of African American experience and moral vision that exist in tension with Europeanized Christianity. For one, Christianity privileges conformity—as argued by Smith—whereas Buddhism assumes that conformity is just another way to distract oneself from the nature of suffering. Secondly, the goal of a Christian life — salvation of the individual soul through a subservient personal relationship to a higher power - is at odds with the Buddhist notion that individualism is a product of the ego, and as such does not end one's suffering, but contributes to a lifelong attempt to elevate the self above the countless sinners seeking redemption. The resistance to conformity in Dreamer and the elevation of the community above the individual point instead to an alternative model of historiography, one that discards the "great man" theory of history to focus on the connections made between people, the communities that fostered the growth of African American culture and values.

In the novel, the inability of King to establish moral grounds upon which the nation can come together is contrasted with stories of strong, historically black communities. These communities - strengthened by affiliation to an African Methodist Episcopal church (AME) tradition - provide structure and support to African Americans denied by the nation-at-large. Bishop, for example, talks about Calvary AME church in Evanston, Illinois, saying, "its rich, never recorded history was hidden inside, stored within every parishioner" (124). He also discusses the importance of oral history to African American culture, relating how, through Amy and her grandmother-Mama Pearl—he knows that the town's older blacks were "mostly craftsmen — plumbers and electricians - transplanted from the South during World War II, whole families that migrated up the Illinois Central Railroad from the Mississippi Delta, from Tennessee and Arkansas and western Kentucky in the greatest mass movement of humanity in 
American history" (125). Evanston, "situated on the canal dividing [it] from lily-white Skokie (125), is one of the "beloved communities" of the novel, a place in which the moral strength and communal values of the African American population has created a refuge from the surrounding chaos.

Communities such as Evanston are crucial reminders of the need to recover African American history. Hidden in local and national historical archives or "stored within" individuals, this history speaks to the struggle of African Americans to exist within a white-dominated national culture that ignored or actively rejected their needs. In Dreamer, the "never recorded" history is given precedence, particularly because much of the history is Johnson's own. Rudolph Byrd describes how Dr. Jennifer Hale — the black Evanston doctor responsible for establishing the "Center Hospital" in the novel that treated blacks refused by white hospitals - is the fictional version of Dr. Elizabeth Hill, who founded the Community Hospital in Evanston as a blackowned and operated facility; Johnson was born in Community Hospital, delivered by Dr. Hill in 1948. Additionally, Robert Jackson, the black carpenter whose company built Calvary AME, is based on Johnson's great-uncle, William Johnson, who built Evanston's Springfield Baptist Church - the counterpart to Dreamer's Calvary AME (Byrd 165). In the novel, Dr. Hale despises the segregation that forces her to "ferry her patients to hospitals on Chicago's South Side" because "too many died on the way... while pariahs to the white population, [her patients] worked in white homes... always struggling and sacrificing to free their sons and daughters from the curse of color that hung over their own lives" (126). Johnson's tribute to Dr. Hill through Dr. Hale is an attempt, therefore, to not only preserve the important local history of Evanston, but also to document the self-preservation of black communities; indeed, one of the "countless black 
lives" saved by Dr. Hale/Hill could easily have been a member of Johnson's family, maybe even Johnson himself.

Evanston, along with other "beloved communities" in Dreamer, preserves and extends a distinctly African American tradition that understands history as central to the present condition. Black communities in Dreamer reject what Ellison refers to as a pattern of racialized social behavior set in motion by Southern whites during slavery. Ellison argues that most whites crave the "sleep of violence or the coma of apathy": "when the individual, whether white or black, rejects that pattern and awakens to the nightmare of his life...the penalty of wakefulness is to encounter ever more violence and horror than the sensibilities can sustain unless translated into some form of social action" (92). This struggle against wakefulness on the part of whites is what Charles Mills refers to as an "epistemology of ignorance," or a collective "agreement to misinterpret the world" (14). Evanston, in the novel, symbolizes a resistance to ignorance and to the violence that perpetuates instead of defuses hate. It is not, the reader is told, "the fabled Promised Land, [but] was a curious pocket of tranquility compared to the Black Belt" (125). Johnson shows how Evanston, with an integrated school system and an "agreement" by parents to allow interracial dating, is a beloved community that, while not perfect, displays a form of racial cohabitation that transcends the violence of surrounding communities. In this example, Dreamer adheres to King's vision of nonviolence by showing how violence, committed by whites or blacks, is ultimately violence against the self, particularly because violence re-inscribes hatred, suspicion, and resentment between people.

The novel advances the notion that the self must be overcome to understand the interconnectedness of time, place, and being. When Bishop returns to the Griffith farm from Chicago, he ponders Smith's spiritual journey and his work at Bethel AME, wondering, "why 
this sacrifice for a community in which he believed himself an outcast?" (181). Smith answers that he hasn't, as Bishop suggests, "got religion," but instead sees no ultimate purpose to his work: 'For a li'l while what I do here is just what I'm doin' and, who knows, it may be beautiful, and maybe nobody won't know 'bout it, even God, but for a second or two it'll make a few of the folks who come through here on Sunday happy" (182). Smith, while still maintaining distance from a religious community, has again found his place among a community of black people. Smith's participation in the church mirrors King's last efforts to recover a sense of strength in community (for King, among the working poor), and this trajectory points to the centrality of community in African American history and culture. James H. Cone outlines this history in A Black Theology of Liberation:

What whites fail to recognize is the fact that all decisions made with regard to what is important or worthwhile are made in the context of participation in a community. It is in the community that values are chosen, because the community provides the structure in which our being as persons is realized. It is not possible to transcend the community; it frames our being because being is always being in relation to others (103, emphasis mine).

Smith's transformation into a member of a community is accomplished through his adherence to a philosophy he recounts to Bishop using the Thai word riabroi, which he defines as "everything together at once, complete, sensible, beautiful, perfect, and natural" (183). Smith, the embodiment of the sacred/secular dualism of African American history, now understands that he is not merely King's "double," and that the two complete each other as part of the pattern of existence; they are, in the final analysis, two poles who attract and repel the other, producing the tension characteristic of the universal order. Smith's notion of riabroi suggests that the true 
nature of the universe and of life itself is one of unity, that the natural state of things, while seemingly in constant flux, is a stable manifestation of an intrinsic order. Therefore, the life of the individual is inseparable from that of others, just as a single moment is inseparable from the web of time.

Presenting experience as part of a vast web of time allows Dreamer to connect African American experience across history. Bishop's revelation of this connection comes when he returns to Bethel for the first time looking for Smith:

Portions of the church dated from different periods, like a palimpsest, reaching back to the end of the Civil War when black couples separated by slavery held mass weddings on this very site, as many as a hundred men and women gathering to exchange wedding vows and have their long-deferred unions sanctified and cemented by the Christian Faith.

The structure was a tissue, a layering of lives and architectural styles based not on the principle of either/or but of adding this to that, and yes of course throw that in too, the Jewish, the Christian, the Greek, the African, the Roman, the English, the Yankee, for these could only enrich the experience of the spirit...I saw a creation that on every level - from purlins to wallplates - transcended the passing of its founders, one that no single generation could live to see completed and thus was handed down and on to those yet unborn for its continual restoration and completion (179-80).

In this passage, Johnson could just as easily have been describing the history of America, a nation that is itself - as Johnson observed in Middle Passage by naming the slave ship The Republic - a palimpsest, a floating signifier comprised of multiple competing, yet intimately 
related, narratives of identity and belonging. In the same instant, the passage also implies the possibility of the postmodern moment; whereas some revel in the ambiguity of meaning and the splintering of identity into various subcultures that postmodernism seems to invite, Dreamer exemplifies a disambiguation through the convergence of contingent identities into the idea of sangha, or non-self. Thus, while postmodernism has tended to be seen as a call to deconstruct culture and narrative - a disassembling of cultural norms and institutions - it is also constructive in the sense that the absence of authority enables one the freedom to investigate what Fredric Jameson has called the "conditions of possibility" of any given form of thought. Despite its overwhelming pessimism, Dreamer find the "conditions of possibility" for the beloved community in the survival of African American kinship and traditions, which makes plausible the continuation of King's vision into the twenty-first century.

\section{Conclusion: Buddhism and the Suffering Sixties}

Dreamer's contribution to the history and memory of the civil rights movement is its focus on suffering, and on the restorative capacity of Buddhist thought to help heal the wounds of the 1960s. Johnson goes so far as to say that King was "at bottom, a Baptist minister...but one whose vision of the social gospel at its best complements the expansive, Mahayana Bodhisattva ideal of laboring for the liberation of all sentient beings" ("Sangha"). In "A Sangha by Another Name," Johnson traces African American history and literature through a Buddhist lens: "The black experience in America, like the teachings of Shakyamuni Buddha, begins with suffering" ("Sangha"). Johnson proceeds to explain how, despite the strength and salience of black Christian tradition, W.E.B. Du Bois and, later, Jean Toomer began to reflect on what African Americans wanted to achieve, and if that achievement could be realized within a Western, JudeoChristian worldview. Accordingly, Johnson says, "people of color find in Buddhism the depths 
of their long-denied humanity.... The emphasis in Buddhist teachings on letting go of the fabricated, false sense of self positions issues of Race as foremost among samsaric illusions, along with all the essentialist conceptions of difference that have caused so much human suffering" ("Sangha"). King's beloved community is the apex of this philosophy and represents the embrace of Buddhist thought within a Judeo-Christian context; it simultaneously allows for African Americans to believe in a Christian God while shedding all of the weight of a Eurocentric Christianity comprised of dual narratives of enslavement and emancipation.

Interestingly, King — the real person and Johnson's character—embodies and also rejects the second of Buddhism's Four Noble Truths: the origin of suffering is attachment. King's decision near the end of his life to devote his energy to the world's poor was a rejection of this Truth, and it firmly established his desire to remain committed to the worldly concerns that he saw result in so much fear, hatred, and death in the communities in which he preached and marched. In this way, Johnson's King revises traditional understandings of the purpose of Buddhist practice. Traditional Buddhist thought advances that a "Middle Way" between the extremes of attachment and asceticism is the preferred path to Nirvana, or an end to suffering. At times, the Middle Way has been interpreted as a solitary path, one that must be traveled without the earthly and human attachments that are the source of suffering. If one is to see King, as Johnson suggests, as a quasi-Buddhist figure, then King's example asks how responsible a state of Nirvana is for the individual in the face of so much human suffering. King's philosophy of nonviolent engagement might itself be considered a Middle Way between passivity and violence, one that encourages readers to conceive of the practical applications of Buddhism to social protest and community organizing. This positioning also implicates readers themselves, and one 
can imagine Johnson asking readers to consider their own desire for engagement, or, perhaps more fitting to his message, the disengagement that he sees in contemporary black youth.

It is fitting, therefore, to see King not as a martyr or Christ figure (who, in much Western art, is portrayed as white), but as a bodhisattva, one who rejects personal liberation and Nirvana in order to serve humanity. Dreamer recasts postmodern concerns in a Buddhist light; the illusory nature of reality and representation that characterizes both is not, as in mainstream postmodern thought, a cause for withdrawing from humanity and reveling in the multiplicity of the modern age, but instead is an opportunity to create new realities that serve humanity and seek to redress historical inequalities. Johnson keeps King's voice alive in Dreamer, and it is importantly a voice that asserts King's humanity and humility above his larger-than-life public persona. Postmodern cynicism often leads to the notion that freedom from fixed social and political identities is an end in itself, but Johnson, through King, shows how the connectedness of life is the only real truth there is and reaffirms that attachment is ultimately a noble cause.

Indeed, African American history is characterized by efforts to establish the beloved community, the Sangha, to construct the modern-day Bethel within which is the ladder that connects humanity and the earth to the infinite spirit of the universe, the "inescapable network of mutuality, tied in a single garment of destiny" (King "Letter from Birmingham Jail"). Johnson advances this notion of destiny in Dreamer, and by doing so he counters the anxiety of a postmodern era in which the anti-finality of narrative has many questioning the existence of absolute truth. There is truth, the novel tells us, in the interconnectedness of being, and in the possibility of a gradual awakening of humanity to the notion that the world's seemingly disparate peoples are in fact joined - a knowledge that will continue to give strength to beloved communities around the globe. Like DeLillo, Johnson urges us to consider what we will do with 
this knowledge; since death is so central to both novels, DeLillo and Johnson are perhaps suggesting that the world is in desperate need of new ideas, new certainties in an uncertain time. Marguerite Oswald's insistence in Libra on the rights of mothers and King's insistence on the rights of African Americans and the poor in Dreamer point to a lack of pragmatism in American culture. They underscore the point that outcasts can form communities and that the American rhetoric of freedom and democracy has to be reinforced through conscious, collective practice, and that none of us are free until all of us are free. 


\section{Notes}

${ }^{1}$ I choose not to capitalize "civil rights movement," despite its popular status as the landmark social movement in the American black freedom struggle, to avoid portraying it as monolithic and in deference to all of the struggles, past, present, and future, to which it is connected. ${ }^{2}$ See Alderman, who describes the efforts of a black activist—Jacqueline Smith—who has spent over a decade protesting the National Civil Rights Museum. Smith's protest "has been literally street politics in that she has lived, eaten, and slept on the sidewalk across the street from the museum" (74). Calling the Lorraine Motel the site of the "National Civil Wrong Museum," Smith distributes literature to tourists and argues that " "the best monument to Dr. Martin Luther King Jr. would be a center at the Lorraine offering housing, job training, free community college, health clinic or other services for the poor"' (74).

${ }^{3}$ In some cases, the debates have taken on a decidedly heated nature. See Baker, who takes black scholars to task for what he perceives to be a self-interested turn in black studies. Detailing how "centrist" and "neo-conservative" blacks have countered the gains of the movement, he argues that while these scholars are prolific, they have contributed to a "myth of racial progress" and that they "ultimately represent a manifest betrayal of the legacy of Martin Luther King" and the gains of the civil rights and black power movements (xii).

${ }^{4}$ See Storhoff, "The Artist," 539-49 for his discussion of Johnson's progressive postmodern sensibilities as an example of "Berkeleyan Idealism," after the philosopher Bishop George Berkeley.

${ }^{5}$ For more about Johnson and Buddhism, see Gary Nash. 
${ }^{6}$ William Nash has argued in Charles Johnson's Fiction that Johnson's later work has moved away from a traditional Buddhist influence and has migrated toward a worldview similar to that of W.E.B. Du Bois, particularly because Buddhism — in its call for detachment from worldly concerns - cannot sufficiently interrogate the experience of racism. However, as Jonathan Little observes, Johnson seems to "intensify" his Buddhist perspective in Dreamer and has otherwise referred to Buddhism as "exactly right for African Americans." See Little, 745. Also, see Malkin for a 2004 interview in which Johnson refers to what he calls "Engaged Buddhism—acting in the world to remove those causes of suffering and evils that have harmed so many people," which he links directly to Martin Luther King ("Buddhism").

${ }^{7}$ In presenting such a simplistic view of African American historiography, I risk perpetuating what Lawrence Hogue calls the "classic African American historical emancipatory narrative" (2) in which the African American is "represented only in terms of his experience of racism" (13, emphasis in original). I do not propose that the "emancipatory" narrative is the only supportive structure available to discuss the African American historical experience. For the purposes of this essay, however, it is the most useful—especially considering Johnson's view in Dreamer that the civil rights movement was a response to the inadequacies of American democracy and the failed promises of emancipation.

${ }^{8}$ In order to separate these italicized sections of the novel with language that I am emphasizing in my analysis, I have removed the italics in quoted passages taken from the King chapters. ${ }^{9}$ In 1958, at a book signing in New York City, Izola Curry, an African American woman in her twenties, plunged a steel letter opener into King's chest in a failed assassination attempt. 
${ }^{10}$ See Farber, 1, for an explanation of how few people had heard "more than snippets of his oratory" before the speech in Washington; however, with live TV coverage, "millions heard King's full prophetic power and were moved."

${ }^{11}$ David Garrow, in his Pulitzer-prize-winning biography of King, cites many of King's close friends, such as Andrew Young, remarking how, in the last year of his life, King “"talked about death all the time" and how he was "spiritually exhausted" (qtd. in Garrow 602). Young also said he thought much of King's despondency came from the decreasing popularity of the nonviolent movement: Young has King asking himself “'Can it really work, will we really succeed, is nonviolence the real way?"” (qtd. in Garrow 602).

${ }^{12}$ See above note concerning Izola Curry.

${ }^{13}$ For more on Nietzsche and postmodernism, see Gregory Smith.

${ }^{14}$ James Baldwin also talks about the danger of living in a dream-state: "We are controlled by confusion, far more than we know, and the American dream has therefore become something much more closely resembling a nightmare" ("Fire" 89).

${ }^{15}$ See Suiter, 243-45 for a discussion of Kerouac's dejection and hostility following negative reviews of Dharma Bums from such figures as popular British Zen philosopher Alan Wattswho called the novel an example of "Beat Zen" that was too self-conscious and lacking depth— and poet Gary Snyder, a friend of Kerouac's, who told Kerouac that his interpretation of Buddhist thought was misogynistic.

${ }^{16}$ See Peniel, who contends that by the late 1950s, blacks in the urban North "formed an unnamed parallel movement" to the civil rights movement in the South that was "cynical about American democracy's willingness to protect black citizens.” Arguing that Black Power was 
"forged" where "cynics and optimists intersected in Harlem, Detroit, and elsewhere," Peniel claims that both civil rights and Black Power "grew out of postwar freedom surges" (43). It seems fitting to locate Smith among other African Americans, particularly veterans of the armed forces, in the above setting instead of within a largely white Beat tradition with little to no connection to African American culture or history.

${ }^{17}$ See Gross for a discussion of the problematic attempts to define race in US history. 


\section{Chapter Five:}

\section{Linking Intelligence to Passion: Alice Walker's Meridian and Postmodern Black Feminism}

Revolution is not a one-time event. It is becoming always vigilant for the smallest opportunity to make a genuine change.

—Audre Lorde, Sister Outsider (1984)

Audre Lorde's observation that "revolution is not a one-time event" drives the spirit of my project as much as it does the present chapter. As early as 1967, a twenty-year-old Alice Walker wrote an essay entitled “The Civil Rights Movement: What Good Was It?” in which she declared that 'if the Civil Rights Movement is 'dead,' and if it gave us nothing else, it gave us each other forever...it gave us hope for tomorrow. It called us to life" (In Search 128). Walker's essay is an example of how even before Martin Luther King, Jr.'s murder in 1968 there were those who considered the civil rights movement to be waning in its influence and relevance. Dennis Chong refers to the "sudden demise" of the movement in the late 1960s as coming from many directions — discord between movement leaders and political leaders, the radicalization of the movement, decreased responsiveness from the government, and increased attention and activism devoted to the antiwar movement (228). Although King himself became more engaged in how human rights issues—including war and poverty—connected with civil rights for black Americans, he was killed before a new movement could take form around his later ideas. However, as I hope to have shown, the authors in this study have contributed to this form by imaginatively connecting readers with the 1960 s in ways that empower them to apply activist principles to their own cultural moment. Walker is one of these writers, and the present chapter explores how she keeps King's voice and spirit alive in her 1976 novel Meridian, published 
during a turning point in African American feminism that I consider representative of a postmodern moment in African American feminist writing.

Before turning to an analysis of Meridian, I discuss a cadre of black women writersincluding Walker, Lorde, bell hooks, and Toni Morrison—whom I argue contribute to a liberationist pedagogy framed by 1960 s activism but applied to the 1970 s, 80 s, and 90 s. $^{1}$ I see this writing as postmodern because it reclaims the revolutionary moment of the sixties in a way that accounts for the fragmentation and contingency of postmodern culture and literary study and, particularly with Morrison, in the way it advocates participatory frameworks for reading. In response to the male-centered politics of the civil rights movement and of the public history and memory of the movement, it creates empowering social, political, spiritual, and emotional connections between black women through a conscious observance of the centrality of African American history in creating a politics of difference that includes all women of color. The 1960s are extremely important to this history, both in the decade's promise to lift the racial and patriarchal curtains separating black women from full consideration in American civic life (even in their own communities) and in the many failures that in some ways strengthened those curtains.

The militancy of some Black Power organizations entrenched patriarchy into the black liberation struggle, paradoxically re-inscribing a debilitating sexism that had already stifled black women's voices for centuries. After the 1960s, some black feminists began to account more fully for these discriminatory attitudes both within and outside of black freedom struggles and sought to create unifying theories that celebrated difference while establishing critical connections among the beliefs and practices that silenced and oppressed people — and especially women—of color. In the creation of a "radical postmodernism" of difference, these writers imagined worlds 
in which a diverse people's experience of various oppressions involved them in a spiritual and political quest to find new ways of approaching the world, together, in order to organize and work against the cruelty of racism, sexism, homophobia, and other forms of cultural and political marginalization. Writing against the grain of a postmodern American body of literature that seemed to establish difference as grounds for parody, cynicism, and a rejection of sustainable theories and values for communal living, this post-1960s black feminism reveals the inherent possibility in creating an alternative postmodern ethics that radicalizes difference as a political opportunity.

A radical postmodern politics committed to antiracism, antiwar, antipatriarchy, and antihomophobia extends the perceived vision of 1960s social movements while offering an alternative to mainstream academic postmodern discourse. One example of the latter is Brian McHale's seminal Postmodernist Fiction (1987), one of the most well known books on postmodern literature and literary style. In the preface, McHale attempts to define his project, arguing that his book constructs the "repertory of motifs and devices, and the system of relations and differences, shared by a particular class of texts" (xi). Throughout, McHale traces the transition from modernism to postmodernism primarily through establishing what he calls "the dominant," or the mode of thought that preoccupied the minds of authors and the themes of their texts; modernism, argues McHale, was dominated by epistemological concerns, whereas postmodernism is concerned with ontology. In a way, McHale's analysis is astute: logic and reason stopped making sense in the period during and immediately after World War II, and an assumed epistemological pluralism dominated what was to become the postmodern era, in which questions about being and the world led to the conclusion that there is no one reality or objective truth. However, the problem lies in what McHale takes as his "particular class" of texts, which 
are predominantly written by white, male authors. As a privileged text in the evolution of postmodern literary criticism, McHale's study ignores the contributions and concerns of writers of color and women.

There is much at stake in constituting postmodernism as defined primarily by white European theorists and white American authors. As Lawrence Hogue observes, "most postmodern African American, women, and American Indian writers do not experience and write postmodernity in the same way as postmodern American white male writers" (x). He explains, "in their fiction they are not merely rejecting/problematizing instrumental reason... and other Enlightenment ideas such as linearity, closure, wholeness, and notions of progress, but they are also interrogating modern Eurocentric (male) subjectivity" (xi). Hogue argues that to these authors, postmodernism presents an opportunity to create new paradigms and to "resurrect" marginalized histories and beliefs (xi). Hogue's belief that white postmodern writers (male and female) neglect to address the process of "otherization" in their texts even while they deconstruct Western Enlightenment tradition marks a break from mainstream postmodern theorization. The black feminist postmodernism covered below reveals how mainstream postmodern thought uncovers the faulty organizing logic of the modern era without creating new subject positions for those most affected by the sociopolitical structures that arose from that logic. Most importantly, issues of epistemology are still at the center for African American women writers who call attention to the ways in which "knowledge" is still structured very much within a Western white male paradigm despite the pluralism associated with postmodern social thought.

Because of their popularity in the classroom as well as their place on best-seller lists, the authors presented here are representative of a pedagogical stance that has sought to establish the grounds for a new liberation movement that accounts for what Audre Lorde calls the "triumphs 
and errors" of the social vision of the civil rights movement (135). According to Lorde, the purpose of their work is not to "condemn that vision but to alter it, construct templates for possible futures" (135). The value of these new visions is in their ability to provide alternative frameworks for approaching the word and the world; instead of being "stuck" in the sixties, these frameworks build on and evolve from the activism that defined the decade. The "templates" Lorde writes about are similar to what Patricia Hill Collins calls "fighting words" in addressing the need to radically reimagine academic curriculum and critical theory; Collins notes how "elites possess the power to legitimate the knowledge that they define as theory as being universal, normative, and ideal" (xiii). To her, "Fighting words" are recognizable by their fundamental stance against injustice, a stance aimed at creating "knowledges of resistance" that counter the hegemonic discourse of the Western political and academic elite (xvi). In her study of fiction by black women authors written in the period following 1960s civil rights organizing, Melissa Walker observes how a process such as Collins describes has led to fiction in which black women authors showcase a pluralistic feminism and activism: "their sensitivity to what others can hear and a determination to speak from and into the times has resulted in an amazing variety of voices making trouble 'visible,' asking the most troubling questions - and being heard" (207). I take Walker's assessment a step further by identifying a strain of postmodern black feminism that attempts to definitively answer the questions that society-at-large neglects to entertain. She hints at such a movement with her title, Down from the Mountaintop, because the work that the above authors advocate involves us all in the slow, trudging walk back up the mountain. Setting their written work against a backdrop of 1960s activism, Walker, Morrison, Lorde, and hooks call us to begin anew the political and social project of building sustainable communities free of the oppressive forces of discrimination and violence. By combining the 
word and the world, fiction and reality, they construct a bridge between the world we inhabit and the better world of our imagination.

Taken together, I argue that the "knowledges of resistance" produced by Morrison, Lorde, Walker, and hooks contributes to a refiguring of theories and practices related to social justice while advancing a radical black feminist postmodernism that recasts the fragmentation and resists the cynicism of mainstream postmodern theory. Such a methodology is defined by its implications outside of the classroom; in imagining "possible futures," the black feminist writings I discuss attempt to reveal how thinking about education, literary study, and social praxis as interrelated terms confronts social theory that divorces thought from action. By invoking the history of black activism (especially among black women) and relating it to the histories of other oppressed peoples, this particular example of black feminism creates a discourse of empowerment from which sustained practices of social consciousness and praxis can be realized and put into use. Accordingly, the content of this chapter-the writing, theories, movements, history, etc.—is anything but "dated," as some contemporary theorists might argue. The issues these authors struggled with still prevent meaningful social change, and the movements (such as Occupy Wall Street) that focus on the economic disparity arising from or exacerbated by neoliberal economic policies and globalism don't always take full account of the ways in which race, gender, and poverty are interrelated. The unofficial history of the OWS movement includes the admission that "some of the concerns raised early in the movement around issues of race continue to be a deterrent for people of color who have not participated directly" (Occupy 116). Other issues stem from racism in the OWS movement, segregated meetings and assemblies, concerns over police brutality, and the failure of OWS leaders to reach out to people of color (117). While the POC (people of color) caucus of OWS organizes and 
sponsors workshops and teach-ins, the "LGBTQ" contingent have felt alienated and marginalized (117). Moving forward, the leaders of the movement plan to look for ways to create coalitions and integrate the issues facing various participant groups. Thus, I argue that looking at the work presented in this chapter can provide one model for how such thinking, organizing, and protesting can be accomplished.

\section{The Rise of Black Women's Writing After the 1960s}

In order to provide some context for the discussion of Meridian and the postmodern black feminism I locate in several black women writers, it is necessary to first quickly summarize the proliferation of black women's writing in the period after the 1960s. This summary is not meant to be exhaustive but merely an entryway into the cultural and academic forces that shaped and were shaped by these authors. When Toni Cade Bambara (then Toni Cade) published her anthology The Black Woman in 1970, women such as Cade, Walker, Lorde, and Nikki Giovanni began to enter the literary spotlight and gain popular and critical attention. In this important work, black women were writing about issues that confronted women of color and that weren't satisfactorily confronted during the civil rights organizing of the previous decade. As Eleanor Traylor writes in the 2005 edition, these women "were (and remain) active participants in an ever-evolving movement" which saw its most revolutionary period during the sixties, during which it "tilled the soil of thought in which the seeds of mid-century and later liberation struggles around the world sprouted and grew strong" (xii). 1970 also saw the publication of Morrison's The Bluest Eye, Walker's The Third Life of Grange Copeland, Maya Angelou's I Know Why the Caged Bird Sings, and poetry by Gwendolyn Brooks, Margaret Walker, Lorde, Sonia Sanchez, and Mari Evans, all examples of a generation of female black writers who rose to literary prominence during the 1970s and 80s. Part of the political project of anthologies like The 
Black Woman was to "chart the steps necessary for forming a working alliance with all nonwhite women of the world for the formation of, among other things, a clearing house for the exchange of information" (Cade 6). An example of such an alliance came a decade later with the publication of This Bridge Called My Back: Writings by Radical Women of Color (1981), which Barbara Smith argues in Home Girls: A Black Feminist Anthology (1983) "has been a document of and a catalyst for" coalitions among women of color and feminists (xliv). Such coalitions had significant impacts on "third-wave" feminism, a term most often used to refer to the third-world feminism that emerged during the 1980s and 90s and which contributed to the multicultural shift in the academy and in popular culture. At the time of Bridge and Home Girls, black women were still struggling to be heard; the anthology All the Women are White, All the Blacks are Men, but Some of Us are Brave (1982), edited by Gloria Hull, Patricia Scott, and Smith, provided a wealth of material for black feminist studies courses which simultaneously issued a call for white feminists and black male scholars to take notice.

Despite gains in sales, audience, critical recognition, and classroom exposure, women of color still confronted the issues of racism, sexism, and classism that made their work necessary. For example, in her essay "Who the Cap Fit" (1987), Joyce Anne Joyce defends her call for a new framework for black literary studies against the attacks of Houston Baker and Henry Louis Gates, concluding that the latter two had "used the obfuscating language and ideas of Derrida, Barthes, Paul de Man, Foucault, Kristeva, Althusser, Bakhtin, and others to cloak their difficulties" with establishing a clear purpose for their own criticism (373). To illustrate her point, Joyce quotes Larry Neal from “And Shine Swam On” (1968): "the black artist must link his work to the struggle for his liberation and the liberation of his brothers and sisters...the artist and the political activist are one" (qtd. in Joyce 376). Joyce contended that Baker, Gates, and 
other elite black scholars had used their positions not to the advantage of black people but to further alienate the black masses from the work that was being done in their name. At the same time, some African American scholars-especially women—worried about being contained within discourses that focused only on race or gender; as Mae Gwendolyn Henderson articulates in her 1989 essay "Speaking in Tongues," these discourses limit black women's writing to "a reading of part of the text as the whole — a strategy that threatens to replicate (if not valorize) the reification against which black women struggle in life and literature" (349). Henderson argues for black women's complexity to be acknowledged and against simply being labeled an "other," and her position successfully critiques the emerging postmodern literary scene of the time for treating black people like objects of study. She writes that black women's complex subjectivity emerges in their writing, which "both affirm[s] and challenge[s] the values and expectations of the reader" (351). In constructing a black women's literary tradition, Henderson encourages a view of African American women that acknowledges the various roles and identities (racial, sexual, political, social) that make up the whole person, instead of focusing on the alienating discourses of race or gender or class that contain and try to define the limits of their subjectivity.

Such attempts have not disappeared because of "multiculturalism" or "feminism" or any other popularized "ism" that has tried to theorize and put into action progressive social concepts. In some cases, such movements have further entrenched patriarchy and isolationism; one need only think of the conservative backlash against women's rights in the 1980s, the continuing violence against women in parts of the Middle East and Africa (as Walker's 1992 novel Possessing the Secrets of Joy, about female genital mutilation, painfully makes clear), the ongoing debates concerning women's reproductive rights around the world, the refusal of some to allow marriage rights for all, or the fervent anti-immigration stance of some US states in the 
beginning of the twenty-first century. In the epilogue to Beverly Guy-Sheftall's 1995 black feminist anthology Words of Fire, Johnetta Cole discusses the "long and ongoing struggle" that characterizes black feminism and how (at the time) contemporary young black women rejected feminism because they thought it meant putting sexism before racism. She argues that white women in the mid-1990s had still not dealt with their own racism, which prevented the building of in-roads between white and black feminists (550). In 2003 Guy-Sheftall and Cole edited another anthology, Gender Talk, which focused on the tendencies of race-specific analyses to ignore gender issues in black communities and particularly the violence against black women in reality and also as portrayed in rap music. Guy-Sheftall and Cole articulate what is, in fact, a global problem; as Ranu Samantrai shows in her book AlterNatives: Black Feminism in the Postimperial Nation (2002), the Black British women's movement (African Caribbean and South Asian) of the 1980s confronted similar issues about race, gender, and the re-inscription of difference resulting from resistance to the dominant culture that continue to plague remaining Black activists throughout the world.

\section{Define and Empower: Radical Postmodernism and Black Feminist Writing After the1960s}

A literary tradition of feminism that supports coalitions between women of color around the globe is one response to the perpetuation of inequality and discrimination facing the world. It may seem strange to begin a conversation about "black postmodernism" with the observations of a white, male author, but Thomas Pynchon's 1966 essay “A Journey into the Mind of Watts" is remarkable in what it says about the emerging postmodern sensibility in American culture and politics. The 1966 riots in the Watts section of Los Angeles began when the city's district attorney refused to press charges against the white cop who, after a car chase of roughly fifty blocks, stopped a car driven by a black man, Leonard Deadwyler, leaned into the car's window 
with his gun drawn, and shot him dead. According to another officer on the scene, Deadwyler's last words were "she's having a baby," a reference to his pregnant wife, who sat in the passenger seat of the car as her husband was killed (“Journey'). ${ }^{2}$ Pynchon observes how the violence of white cops against black people, repeated over and over in South-Central LA, is representative of the cultural differences between white and black people:

While the white culture is concerned with various forms of systematized follythe economy of the area in fact depending on it - the black culture is stuck pretty much with basic realities like disease, like failure, violence and death, which the whites have mostly chosen — and can afford — to ignore. The two cultures do not understand each other, though white values are displayed without let-up on black people's TV screens, and though the panoramic sense of black impoverishment is hard to miss from atop the Harbor Freeway, which so many whites must drive at least twice every working day. Somehow it occurs to very few of them to leave at the Imperial Highway exit for a change, go east instead of west only a few blocks, and take a look at Watts. A quick look. The simplest kind of beginning. But Watts is country which lies, psychologically, uncounted miles further than most whites seem at present willing to travel ("Journey").

Pynchon argues that there shouldn't be any mystery to Watts, since "everything seems so out in the open, all of it real, no plastic faces, no transistors, no hidden Muzak, or Disneyfied landscaping or smiling little chicks to show you around. Not in Raceriotland" (“Journey”). "Escape," a cornerstone of the "LA scene" Pynchon invokes, is not a luxury for the black population of Watts; as Pynchon observes, "Watts is tough; has been able to resist the unreal" (“Journey”). Madhu Dubey echoes Pynchon's claim a half-century later in a book on black 
literary postmodernism, writing, "if the referent has waned under the pressure of digital technologies, African-Americans have managed to maintain a connection, at once mystical and visceral, to material reality" (8).

Pynchon — as perhaps the foremost exemplar of postmodernity in American literatureimplies in this essay that African Americans have always lived in what he terms a "pocket of reality" inside the white fantasy that is America. This analysis, which comes at what many perceive to be the beginnings of the postmodern era in literature, has significant implications for academic postulations of postmodern theory, particularly in the ways in which African American culture and history have been systematically marginalized in discussions of postmodernism. bell hooks writes of the "coded familiarity" with which postmodernism is often discussed in (white) literary conversations. Furthermore, in addressing the concerns of black women, she argues that even the Black Power movement of the 1960s was "influenced by perspectives that could easily be labeled modernist" because it conformed to a "modernist universalizing agenda" that failed to critique patriarchy as a master narrative (418). hooks advocates a "radical postmodernist" agenda to replace the black militant voices stifled by repressive state practices or their own masculinized politics.

This radical postmodernism, suggests hooks, is a new way to articulate the demands of a black liberation struggle; she considers a "black postmodernism" to be "fertile ground for the construction of empathy-ties that would promote recognition of common commitments, and serve as a base for solidarity and coalition" (420). Instead of reducing black experience(s) to historical commonality, a black postmodernism interrogates the breadth of African American culture and identity in order to define black subjectivity as "the quest to find ways to construct the self and identity that are oppositional and liberatory" (hooks 422). Postmodernism is suitable 
ground for an African American political project, agrees Dubey, because "African-Americans can be cast in [a] double role — as both the worst victims and the redemptive agents of the postmodern condition" (8). The writings of Lorde, Morrison, Walker, Smith, and hooks exemplify the desire in the post-1960s era for the creation of "empathy-ties," especially in their insistence on interracial cooperation among women to decenter the cult of masculinity in US culture and to promote an antiracist social praxis. The oppositional politics hooks advocates is also a hallmark of the activism of these authors; tired of the Marxism, communism, liberalism, black nationalism, and other -isms that both organized and dissolved so many of the groups pushing for social change in the 1960 s, the politics they write of are concerned primarily with opposing, not resurrecting, the dominant ideologies which have heretofore structured civil society around the globe.

Looking back at the 1960s in all its complexity can produce a sense of urgency that correlates with direct action. So far, I have sought in this project to employ literature about the 1960s to show how various authors situate the decade in terms of cultural memory and social praxis; the role of literature in extending the work of 1960s activism is in part its ability to imaginatively connect with readers and encourage them to think about their own relationship to the past and to their communities. Literature can shake up popularized views of the 1960s and about activism in general to promote a more conscientious mode of historiography. Smith contends that "the sixties often take on the proportions of a myth, a myth which does injustice both to the achievements and the failings of that era," when in reality, "one of the sixties' greatest gifts was providing a living, breathing sense of radical political possibility for those of us who were open to embracing it" $(167,168)$. The intent of Smith's writing is to explain why we must remain "open to embracing" political change and why, according to Smith, the possibility 
of change depends upon keeping activism “alive” through “constant use” (169). Smith's essay "Doing it from Scratch" (1995) testifies to the power of grassroots organizing and makes an important distinction between the symptoms of racism - such as unequal access to economic and political rights, opportunities, and privileges - and racism as an idea, the destruction of which remains the ultimate goal of an antiracist revolution. Smith reveals how an antiracist campaign necessarily touches on other forms of oppression, since the linked nature of systems of oppression connect the struggles of the poor, those who identify (or who are identified) as LGBT, the nonwhite, and women. Her writing helps to keep such issues on the surface of American political discussions, while the continued scholarly work on that writing can bridge the gap between academic and popular consciousness. Closing this gap is crucial since, as Smith points out, "I don't live in the women's movement, I live on the streets of North America" (101). Radical, postmodern black feminism thus capitalizes on contingency as a source of strength and political identity and merges academic theorizing with the sort of pragmatic philosophy that hopes to include the poor, working-class, and nonacademic in organizing against injustice.

Audre Lorde, along with Smith, has helped pave the way for feminist lesbians of color in the academy while remaining committed to helping those outside of it. In discussing “transforming silence into language and action," Audre Lorde writes against the imposed and self-imposed silences of women of color: "We can sit in our corners mute forever while our sisters and our selves are wasted, while our children are distorted and destroyed, while our earth is poisoned... and we will still be no less afraid" ("The Transformation” 42). Lorde first presented this argument at the 1977 MLA conference in Chicago as part of the "Lesbians and Literature Panel," the type of designation she later argues further compartmentalizes lesbians into a distinct category unrelated to the larger issues of academic politics and study ("The 
Master's Tools" 110-11). In that other talk two years later, Lorde extends her previous argument to conclude in "The Master's Tools Will Never Dismantle the Master's House" (1979) that "in our world, divide and conquer must become define and empower" (112). The "silence" suffered by women of color around the world can be combatted in part in the academy, according to Lorde, through a conscious effort to define their linked positions and to empower each other to work together for change. She talks about the power of writing and theorizing, claiming that "in a world of possibility for us all, our personal visions help lay the groundwork for political action" (112). This characterization of writing — and speaking — about change responds to the limited number of outlets for women of color at the time; Lorde devotes much of her writing - as did Smith — to the realization that even academic feminism was occupied predominately with a white, Anglo-American worldview that excluded women of color from the political organizing engaged in by mainstream feminists.

This separation between white and black feminist organizing is also treated in Angela Y. Davis's Women, Race, and Class (1981) as tradition: concerning Susan B. Anthony and the women's movement, she writes, "Bourgeois ideology—and particularly its racist ingredients— must really possess the power of dissolving real images of terror in obscurity and insignificance, and of fading the horrible cries of suffering human beings into barely audible murmurings and then silence" (121). This is the silence about which Lorde writes, a silence both real and manufactured through neglect; a carry-over from the historical white supremacy of American culture, Davis finds it resurfacing in the rape of Vietnamese women by American G.I.s and in the failure of white feminists to recognize working-class black women as equal partners in suffering.

Lorde, Davis, and Smith seek to transform this silence through empowering women to form coalitions that welcome and use difference as a strategic foundation for postmodern 
identity. This identity is postmodern in essence because of its characteristic amalgamation of different histories, stories, cultural traditions, and political ambitions. At its core it is comprised of the notion that community, as Lorde defines it, "must not mean a shedding of our differences, nor the pathetic pretense that these differences do not exist" ("The Master's Tools" 112). Lorde implies that the splintering of identity and the seeming impossibility of unifying structures that accompanied postmodern cynicism is not an obstacle, since "Black people are not some standardly digestible quantity" ("Learning” 136). In fact, argues Lorde, it is the connections made among systems of oppression that reminds us how difference is the key to understanding liberation; in short, it is our difference (defined against the established and perceived norms) that unites us against the common enemy of tyranny: "There is no such thing as a single-issue struggle because we do not live single-issue lives" ("Learning" 138). This is one of the many lessons of the 1960s, writes Lorde in "Learning from the 60's" (1982); in it, she offers a vision of a movement that considers the complexity of social relations: "The answer to cold is heat, the answer to hunger is food. But there is no simple monolithic solution to racism, to sexism, to homophobia. There is only the conscious focusing within each of my days to move against them, wherever I come up against these particular manifestations of the same disease" ("Learning" 136-7). The problem with viewing the 1960 s as a distinctive period is that such a view divorces one from the struggles of people of that era; as Pynchon showed in Vineland (1990, the subject of chapter two), it is necessary to find ways to connect people across history and to stay in conversation with the ideas and tactics used by those people to practice resistance and realize concrete goals. The power of a vision such as Lorde's is in its ability to form these connections and benefit from the diversity offered by such a model.

Transforming silence is not always easy, and Toni Morrison's work has often consisted 
of pained (and painful) explorations into how we might begin to "speak the unspeakable." In fact, Morrison has devoted much of her career as a public intellectual to revealing just how important it is for black intellectuals to acknowledge the need for community:

When we take on these issues and problems as black intellectuals, what we are doing is not merely the primary work of enlightening and producing a generation of young black intellectuals. Whatever the flash points are, they frequently have to do with amelioration, enhancement, or identification of the problems of the entire country. So this is not parochial; it is not marginal; it is not even primarily self-interest (“African American”).

This argument, which appears in an essay in Princeton Today (1993), is an example of the call to action given by black feminists that advertises problems facing marginalized populations as the central cause of suffering around the world. Morrison's strategic posturing states a concern for national issues, a position that advocates moving the margin to the center. Given academic postmodernism's tendency to “de-center” American popular culture and mythology, Morrison's remarks contribute to the program of radical postmodern praxis. The authors discussed here are central to what Linda Hutcheon calls the "decentering” of postmodernism: she observes how African American and feminist traditions, particularly those arising from 1960s activism, have "shown how it is possible to move theory out of the ivory tower and into the larger world of social praxis" (16). Arguing that African American literature in the civil rights era of the 1960s has had direct cultural and political implications in terms of both public policy and in the structuring of academic disciplines, Hutcheon notes how authors like Morrison and Walker have "offered alternatives to the alienated other, the individual subject of late capitalism" that she identifies as "collective history and a newly problematized sense of female community" (62-3). 
Indeed, it could be said that Morrison started such work in the 1960s in her position as an editor at Random House, where she "nurtured the careers of such writers as Toni Cade Bambara, Lucille Clifton.... and Gayl Jones" (King 3). These women must be considered alongside of the authors I mention in this chapter as contributing to the black feminist consciousness of the postsixties era; by helping to bring their work into the world, Morrison shows an early commitment to producing literature that renews African American and feminist viewpoints at a time in which the civil rights movement was, for some, fading from public consciousness.

Morrison's purpose as a writer is best captured in her notion of "rootedness." According to Morrison, the novel "should be beautiful, and powerful, but it should also work" (58, emphasis in original). Claiming that good writing has something in it that "opens the door and points the way," she presents the novel as a means to explore the connections among individuals and communities, the living and the dead, and the various worldviews that keep the human race in perpetual conflict ("Rootedness" 58). For Morrison, the communities she writes about (and personally advocates) are wholly inclusive: the feeling of rootedness cannot exist without the presence of ancestors, without the safety to be an individual protected by a community, and even without those members who occasionally (or characteristically) create conflict. For these reasons, Morrison's conception of a black feminist consciousness is incomplete without the men against whom they are often set in popular perception of feminist theory; she writes, "any model of criticism or evaluation that excludes males from it is as hampered as any model of criticism of Black literature that excludes women from it" (64). Morrison's inclusion of men in the development of feminist models is especially important because of the ways in which she links her work - and thoughts - to action; any model of activism that practices exclusionary politics of any kind risks, as Morrison notes, falling into the same patterns of oppressive behavior as those it 
excludes.

Accordingly, Morrison's notion of community involves authors, scholars, and readers in a cooperative network of mutual concern for the world and for basic human rights. In "Rootedness," Morrison explains how the dynamic between author and reader should function: "I have to provide the places and spaces so that the reader can participate. Because it is the affective and participatory relationship...to have the reader work with the author in the construction of the book [that is] important" (142, emphasis in original). Morrison articulates something foundational to the argument I put forth in this chapter, that the "affective" qualities of a text—along with its political message(s) — can inspire readers to grasp the importance and necessity of working for change. As Melissa Walker contends, Morrison's novel Song of Solomon (1977) is just one example of how Morrison writes about "the dangers of trying to live entirely in the private sphere" (133). Particularly through the comparison of male characters Guitar and Milkman, Song is a text that explores the private lives of black people who, for a number of reasons, chose not to participate in efforts to overturn the racial status quo in the US during the 1950s and 60s. Walker argues that the novel is "about the other side of the black community, the hundreds of thousands, perhaps millions, of black Americans who were absorbed in their own personal struggles and conflicts: the 'Guitars' disabled by deprivation and hatred, the 'Milkmen' rendered helpless by coddling and egotism” (144). She observes that contemporary readers are in a similar position to those reading Song in the 1970s: "They have a choice of participating in the creation of or withdrawing from the public, historic text," and those who do participate "write themselves into the crossing of history and the fiction of the self and in the process affirm the inevitable historical subtext of all our lives" (147). Conceiving of reading as a participatory act is a radical move that both reintroduces the author as a legitimate subject 
for critical inquiry and establishes the grounds for an ethics of reading. Walker structures the response to Morrison's work in terms of free will; readers have the choice to respond or withdraw. To Morrison and the other authors covered in this study, this choice has to do with more than our relationship to text and reflects our willingness to see our selves and each other as cohabitants of an earth desperately in need of change.

In Anything We Love Can be Saved (1997) Alice Walker comments on this work, taking on diverse subject matter ranging from the African American civil rights movement to female genital mutilation in Africa, the relationship between the US and Cuba, and even her trials and tribulations as a cat owner. These various threads are tied together under the banner of activism; Walker begins by revealing her earlier self-doubt about her commitment to the civil rights movement when she lived in Mississippi from 1967 to 1974. She recalls feeling "ashamed" of being someone who predominantly wrote about the movement and taught others the significance of it and of not adopting a more "radical" position. Through the act of writing, however, Walker came to realize that the shame she felt concerning her "own small stone of activism" is the very reason many choose not to participate, that "the tragedy of our world" is in the decision of individuals to feel insignificant in the shadow of larger figures and events (xxiii). Similar to Lorde's decision to not sit "mute in a corner," Walker's realization turned into a foundation for a lifelong activism based on an unwavering belief in "the love of the world and each other." The metaphor of the "small stone of activism" speaks to the creation of communities built on a shared commitment to human rights and to the dignity of all forms of life on earth. Her own "small stone," the catalogue of her written works, testifies to the lasting power of literature to create imaginary worlds that reflect the anxieties, conflicts, and suffering that mark our collective existence. The value of Walker's work is in her insistence that such a world is worth saving, 
revealed in those moments when she offers readers moments of clarity, grace, and wisdom as part of a worldview that rejects defeat and promotes a conscious resistance to cruelty and suffering.

Walker's approach to her art and the world is grounded firmly in the belief that selfrealization leads to a process of healing within the self that can then begin to be expressed outwardly. Moreover, as with Morrison, there is a synchronicity across generations of healing that can occur through a conscious observation of the suffering of one's ancestors and a devoted practice of bringing that suffering to bear in one's actions in the present. As Walker says later in 2006 in We Are the Ones We Have Been Waiting For: Inner Light in a Time of Darkness, "what heals ancestors is understanding them...they can only be healed inside us" (109, emphasis in original). She warns that "this is not a time to live without practice," and that, however one achieves the "inner light" about which she writes, "we will be doubly bereft without some form of practice that connects us, in a caring way, to what begins to feel like a dissolving world" (109). The "dissolving world" is one in which we lose our necessary connection to the earth and each other, a world without practice, belief, and the will to carry on the legacy of our ancestors into the coming future. For Walker, restoring women — especially black women — to a place of prominence in society gives due reverence to those female ancestors who, even in the horrific state of bondage, fought for the future of their children in a land that denied them even the most basic human rights. For Walker and Morrison, keeping this history of black female activism alive is necessary for healing to begin within the self and in black communities across the US. Walker's feminist impulses grew out of her own healing after the disappointments of the civil rights movement; her later work exhibits a conscious desire to reframe civil rights as an issue affecting women of color more than anyone else. Through her writing, she seeks companionship 
and unity with other women while drawing strength from the women who have historically fought alongside of or in spite of the men in their communities.

Walker's commitment to healing in her work draws together notions of ethics and aesthetics to propose that the value of literature is in its ability to promote insight, wisdom, selfrespect, and empathy for others. She has consistently sought to answer what Martha Nussbaum refers to as "a single and general question: namely, how human beings should live" (15). This is a question that for Walker must be studied partly outside of an Anglo-American tradition. Similar to Collins and Joyce, Smith writes that "the entire problematic of value and evaluation has been evaded and explicitly exiled by the literary academy" in favor of the proliferation of methods of interpretation (17). Walker, in opposing the academic preference for high theory, chooses to focus on the reasons for methodology in the first place; as Harold Bloom argues, Walker's criticism is "directly connected to the way people live" and forms "meaningful narratives that can both draw attention to problematic conditions and provide hopeful alternatives" (86). Walker has discussed her dislike for literary criticism, particularly in how "you miss so much... you have to sort of shape everything you see to the way you're prepared to say it, instead of the way it reveals itself to you" (Wilson 320). To see the world "as it reveals itself" is to open the mind to possibilities, and through that opening, to allow oneself to be connected to other lives and ideas, a notion similar to Morrison's "participatory" text. The act of reading ethically — which encourages collaboration with the text, requires a dismissal of traditional principles of aesthetic value, and seeks an empathic connection between the reader and the characters/actions on the page—is one of the practices that can reveal the world to readers. High theory, like the "coded language" Norman Mailer rails against in Armies of the 
Night (the subject of chapter one), creates a hierarchy of knowledge that reveals a very limited world to a select, elite audience.

Through her attempts to reveal the world to her audience, Walker has developed a pragmatic philosophy she refers to as "conscious harmlessness" (Anything 42, emphasis in original). Violence, she argues, is symptomatic of the human race's “insufficiently examined hatred of itself" (42), a hatred which also manifests in the differentiation of human beings based on invented categories such as race, gender, and sexuality. The solution is to commit oneself to a program that supports healthy communities and social progress, a program that recovers "the irresistible need of black people to give contemporary witness to struggle [that] infuses them with life" (Anything 54). This act of witnessing is a source of "soul nurture" for Walker, and it is connected to the act of writing; through it, she links her heart to her hands, reaching out to "the living and ancestral dead," and also to her brain, which links "intelligence_political and otherwise- - to passion" (Anything 55). In using her writing to reach out to readers, Walker attempts to "infuse" those readers with life, to promote a new understanding (guided by previous generations) of struggle in the modern world. This pragmatic approach to literary production places her in conversation with Richard Rorty, whose "opposition to cruelty" (discussed in chapter two), established in part through a concentrated effort to interact with texts, echoes loudly with Walker's "conscious harmlessness" in the collective call for spiritual renewal in the postmodern era.

In Anything We Love, Walker links the historical suffering of black people in the US to the damaged relationships within black communities. In her critique of the cult of hypermasculinity among the leaders of the Black Panther Party, she notes how the effects of racism and white male privilege have proven especially harmful to the black male ego. The result, she 
suggests, is that although black people fought side-by-side in the civil rights movement, the masculine and militant impulse of some civil rights organizations empowered blacks generally while at the same time undermined the status of black women in the movement. Writing about David Hilliard, Huey Newton, and Eldridge Cleaver, she observes how "all of these men abused women, and apparently thought little about it. Kathleen Cleaver was beaten by Eldridge. Huey had women beaten and was charged with the shooting death of a seventeen-year-old who was selling her body to make a living. She allegedly called him a punk" (159). Walker argues that the word "punk"- - which signified homosexuality_-was in part responsible for the violence and selfhatred she identifies as the driving force behind the male Panthers' view of women. She explains how it "isn't really fear of the police or the FBI...they absorb devastating losses from vicious police raids and murders...it is the charge of being a punk that sends each and every one of these warriors into conniptions" (160). However, instead of relying on a simplistic narrative that once again accuses black men of being innately anti-gay, ${ }^{3}$ Walker highlights the complexity of the word "punk" in the masculine culture of the Panthers:

These were men who loved, admired, and were sometimes in love with, each other. They were confused by this. Who, at the time, after all, except perhaps James Baldwin, could have taught them that love is the revolutionary emotion, partly because it cannot be limited, cannot be compartmentalized, cannot be controlled. But of course Baldwin, by Cleaver's definition, was a punk. They were also men who grew up without fathers...men who learned manhood from white men pursuing fake justice and bogus law and order on television. They might, like Hilliard, adore their mothers, but they dared not emulate or identify 
with her strengths: love of family, devotion to kin and mates, patience with children, humble service to the community (160).

If love, as Walker contends, is "the revolutionary emotion," then black men have been led astray by following the example of a militaristic white male culture that has historically displayed its own sense of strength through exclusion of and violence towards nonwhites. For Walker, then, the violence of black men is many times directed inward, toward themselves and other blacks, since black-on-white violence has often been met with harsh judicial and extra-judicial responses toward black communities by whites. On the other hand, a philosophy of "conscious harmlessness" adopted by black men could transform hatred into love in defense of each other and their communities, although the adoption of this philosophy is dependent upon black men first embracing their roles as fathers, brothers, husbands/partners, and community leaders.

Walker's juxtaposition of conscious harmlessness with the misogyny and homophobia that marred the legacy of the Black Panther Party helps establish "empathy-ties" between activists and generations. Like Pynchon in Vineland, Walker invokes the 1960s in order to learn from them and to recover the possibility of meaningful social action. Her critique of the Panthers is less a judgment than an attempt at understanding; some Panther activities, such as the Free Breakfast for School Children initiative and various other social welfare initiatives referred to as "Survival Programs," pointed to the oppositional, community-based organizing Walker and others advocate. ${ }^{4}$ However, even if these programs had not been infiltrated or sabotaged by the FBI, Walker shows how the poor leadership of the Panthers ultimately precluded them from involving other groups — such as those committed to feminism or gay rights—-from participating in activities meant to strengthen the community. Despite the seemingly harsh mode of her attack on the Panthers, Walker uses this example not to condemn but to instruct; she ultimately blames 
a white supremacist, patriarchal culture for producing such men and thereby warns her readers that any movement toward change must first begin with an honest and thorough examination of the relationship between the self and others.

As the women in this chapter explain, this understanding provides a context for debate and, hopefully, progress. They argue that those in the academic community must also work at revising their roles in the classroom and in the communities they serve. Their work encourages scholars, especially those who consider, research, and write about issues of sex, race, class, economics, politics, the environment, and other social concerns, to bridge the gap between the university and the community to first understand and then help those who could benefit from their access to resources. This kind of progress involves more than just curriculum changes or a new way of thinking about pragmatism in research in publishing — it involves a restructuring of the modes of communication and social organizing that have served to divide instead of unite people. It also involves a common stance against suffering and cruelty despite resistance from authority, such as when Walker and other activists associated with Code Pink: Women for Peace were arrested for crossing a police line outside of the White House on the eve of the war in Iraq. ${ }^{5}$ It involves creating alliances, such as those developed through the Audre Lorde Project, which serves "Lesbian, Gay, Bisexual, Two Spirit, Trans and Gender Non Conforming People of Color" in the New York City area, but which counts heterosexual and white volunteers among its ranks (alp.org).

The women in this chapter practice Neal's call to be artist/activists who use positions of relative privilege to serve the interests of the larger community, particularly those facing various forms of discrimination and injustice. By providing and living a model of pragmatic scholarly activism, they contribute to a radical black postmodernism that uses the postmodern premise of 
multiplicity to establish kinship networks devoted to social justice. The practice of this model remains the crucial project for the twenty-first century. Like Charles Johnson and Alice Walker, hooks relies partially on a Buddhist worldview to articulate how to move forward:

Great movements for social justice have occurred, in civil rights, in women's rights, and so on, but these movements have also been deeply flawed, in that they could not sustain themselves...In the beginning, people push against an outward enemy, but once that push is over, things become like flat soda. What's needed is a Buddha-like process of self-actualizing that spreads into the political world. Then you don't have to fall into an abyss of despair saying, 'We failed. We didn't achieve racial justice....' As we know from Buddhism, if we look for the end, we will despair and give up and not sustain our efforts. But if we see it as a continual process of awakening, we can go forward (“Love Fights the Power”).

The "continual process of awakening" is reinforced by the conscious practice of harmlessness and a participatory relationship to texts that explore the nature of our existence and our responsibility to the earth and each other. Next, I turn to Walker's Meridian as an example of one of these participatory texts that turns a coming-of-age story into one in which young people's transition into adulthood comes (or should come) with the responsibility of providing for the needs of others as well as the self.

\section{Called to Life: Meridian and Activism in the Wake of the 1960s}

Walker displayed her notion of "conscious harmlessness" two decades before Anything We Love when, in her novel Meridian, a young black woman is "called to life" by an act of terror and violence. Meridian Hill is a teenage mother who lives with her son, estranged from the boy's father, when the apartment of a group of young black activists just a few doors down is 
firebombed, killing three children and at least one adult. Meridian, who thinks "nothing like this had ever happened before. Not in this town," experiences a shift in consciousness as a result of the bombing, which sets off a reaction within her that links her to the history of struggle in the US by those blacks and Indians who were exploited and killed by whites: "And so it was that one day in the middle of April in 1960 Meridian Hill became aware of the past and present of the larger world" (67). The bombing, which calls Meridian to a life of activism, also signals her transition to adulthood; in setting the course for her life, she must abandon her roles as mother and daughter to serve the entire black community, a choice which leaves her, for most of the novel, without a place to call "home."

Meridian explores themes of civil rights, alienation, sacrifice, historical legacy, gender roles, religion, and black communal life largely through the lens of a coming-of-age story at the center of which is a lesson in humanity and ethical responsibility. Meridian, who begins to follow the traditional path of black women in the novel (marry young to a good man, have children, be a sacrificing mother who dutifully attends church and keeps a nice house), discovers that to answer one's calling an individual must sometimes diverge from a course set by others. ${ }^{6}$ After she stops attending high school to take care of a baby she does not want, she suffers through postpartum depression until the bombing, shortly after which she joins a group of activists, is assigned clerical work, and is eventually offered a scholarship financed by white liberals to attend Saxon College, an opportunity which leads her to give up her baby and become, in her mother's eyes, exiled from traditional black womanhood. Through multiple encounters with violent, racist police and white townspeople, Meridian works and protests her way through college, suffers through a physically debilitating psychological illness marked by paralysis, blindness, and anorexia, falls in love, experiences heartbreak, and finds her place among the 
poor, downtrodden but proud blacks of the rural 1970s South.

Walker's tale revises the grand narrative of high-profile civil rights marches and national civil rights organizations to focus on those who chose to bring the movement to the people, those who describe themselves simply as "people who ask people to vote" (218). Meridian's transformation involves self-healing and is symbolic of the process through which history, memory, kinship, and community become amalgamated in the spirit of a people devoted to peace, love, and human progress. Walker's philosophy of self-love directed outward is exemplified in Meridian's journey, which imparts a message to readers: at the center of the novel is the unwavering belief that, as Michael Hames-Garcia notes, freedom "must be understood ultimately as a practice, rather than as a possession or a state of being" (L). To "practice" freedom means to live intentionally in the service of humanity; the crucial project of the modern age, as displayed by Meridian, is to recover those aspects of humanity that have been obscured by historical amnesia and a complacent acceptance of a status quo that continues to reproduce inequality.

Meridian also acts as an entryway into the history of regional, grassroots voter registration and civil rights organizing throughout the South in the 1960s. As such, the novel could potentially inspire readers to search for more about local civil rights campaigns and to bring these smaller movements to the forefront of civil rights memory. Roberta Hendrickson argues that "in remembering the dream, [Walker] reaffirms the Movement's vision of freedom" and "passes on the story" to "future generations... inspiring them to continue the struggle" (126). Susan Danielson contends similarly that especially for those readers who have participated in social movements in the 1960s and 70s, Meridian "can help us recall and reclaim the past with appropriate complexity and love" (318). The past is presented in Meridian as a portal through 
which one can spiritually connect with one's ancestors and, through communing with the dead, can rediscover the importance of kinship and community in the struggle for justice and reconciliation. Wholeness - on a spiritual level — is dependent upon this ancestral connection in the novel, and Walker suggests that only by giving due reverence to the past and to those who fought for us can we reach any sort of self-realization. Like Chaym Smith and Matthew Bishop in Charles Johnson's Dreamer (see chapter four), Meridian is fulfilled in part by a conscious recognition of the layered tissue of history and the intertwining roots of community and belonging among African Americans.

Meridian is, to some degree, Walker's intervention into the large-scale, televised memory of the civil rights movement characterized by the yearly ritual of watching Martin Luther King's “I Have a Dream" speech as it was filmed at the 1963 March on Washington. She instead highlights the work of many young men and women, white and black, who chose to bring the movement to the people most in need - the poor, sometimes illiterate black people of the rural South. This was dangerous work, for as Belinda Robnett explains, "direct action in the rural south was a prescription for death" (140). Indeed, the title of Walker's novel recalls Meridian, Mississippi, where in 1964 the bodies of civil rights workers Andrew Goodman, Michael Schwerner, and James Chaney were found buried two months after their disappearance following a visit to a neighboring black church which had been bombed by white supremacists. The town of Meridian was also home to an office of COFO (Council of Federated Organizations), an umbrella group of members of CORE, SNCC, and the NAACP that operated in isolated areas of the deep South (Robnett 141). According to Robnett, since small towns in the South were less visible to the media, regarded outsiders with suspicion, and were in large part cut off from communication with and assistance from larger civil rights organizations, workers had to endure 
harsh conditions to recruit members and register rural blacks to vote (141). Since rural blacks often feared white mob violence as a possibility of everyday life, COFO workers had to establish a network "built specifically upon trust and interpersonal community ties" (Robnett 141). It is precisely these tactics that Walker displays in Meridian, which reveals both the danger of civil rights organizing and the stresses that plagued the movement from within.

Meridian's work in the South is framed within three crisscrossing narratives. The first, which gives the story context, consists of the interrelated tales of suffering, strength, and community found amongst the poor blacks Meridian and others meet while attempting to register voters; the second is Meridian's journey of self-discovery, sacrifice, and healing as she comes to terms with the feelings of rootlessness and inadequacy that result in her mysterious illness; the third details the complicated love triangle between Meridian, her sometimes-lover Truman Held, and a white woman, Lynn Rabinowitz, who joins the movement and with whom Truman falls in love and to whom he eventually gets married. Each narrative serves a distinct purpose in telling the underground story of the civil rights movement: the stories of small, rural black communities in the South and the intimate portraits created through Walker's characters underscore the human dignity of those for whom civil rights workers fought, while Meridian's activism and troubled relationship with Truman and Lynn highlight the complicated personal, sexual, and racial dynamics that sometimes impeded the kind of interracial organizing of which Walker writes.

These three narratives are established in the novel's opening, set in the early 1970s, as Truman arrives in the small, segregated town of Chicokema, Georgia, having driven from New York City to track down Meridian. As he pulls into a gas station, he sees people running toward the town square because "that woman in the cap" is again stirring up trouble (3). As it turns out, the woman in the cap is Meridian, who is leading a group of black schoolchildren toward a 
traveling circus trailer to see a mummified body, a spectacle at the time only open to white audiences. The commotion is caused not just by Meridian's actions, however, but also by those of Chicokema's white community; at the center of the town square, next to a statue of a confederate soldier, is a white tank with red, white, and blue ribbons that the town's whites bought to intimidate "outside agitators," or civil rights workers (4). As the town watches events unfold, Truman asks an old black man why the town is so segregated, since "the Civil Rights Movement changed all that!" (5). The man, who simply replies, "I seen rights come and I seen 'em go" (5), challenges Truman's naïve optimism by pointing to the entrenched racial discrimination endemic to Southern US culture. The tank, painted white (and which crushed the right leg of the confederate statue as it was being parked in the town square), is symbolic of the tenacity with which some whites in the novel cling to the notion of white supremacy and a segregationist social order. The civil rights movement may have chipped away at this order-as the tank crushed the soldier's leg — but in the novel racism is still very much alive, a monument to a history of discrimination and violence towards nonwhites.

Meridian's victory against the tank represents the nature of civil rights activism in declaring that freedom is, again, best understood as a practice instead of an end goal. One learns that, rather than become involved with a group of revolutionary blacks discussing the efficacy of violence and killing in New York, Meridian has decided to move "back to the people...like Civil Rights workers used to" (18). In the early 1970s, Meridian's best friend from college, Anne Marion, and other disillusioned blacks had assembled to take stock of the gains - and, more importantly, the losses — of the 1960s to determine what could be done to re-ignite the movement. While Meridian struggles with the notion of violence and wonders to herself if she would be willing to kill another human being to advance the cause of black people, it is 
important to the novel's message and to Walker's philosophy as an author that Meridian ultimately rejects such tactics (although her rejection is tenuous) and chooses instead to live among those who are most in need of someone to organize and defend the community. When Meridian is carried home by four black men after confronting the tank, kicking down the door of the circus trailer, and (when the children are out of view) collapsing from paralysis, the waiting Truman chastises her for performing in ill health. She responds, "They're grateful people...they appreciate it when someone volunteers to suffer" (12, emphasis in original). By seeking to understand and live the suffering of the black communities she assists, Meridian, as a performer, is suggestive of what Patricia Riley calls "Native American and African tribal shamanistic traditions" (248). Referring to Walker's mixed Native American and African heritage, Riley discusses the fusion of traditions in Meridian, and how the trances, visions, and paralysis she experiences point to her role as a faith healer of sorts in the community, a spiritual guide who is repaid in offerings of food and animals, causing an incredulous Truman to remark that "one man even brought a cow!" (12). Meridian is thus more than an activist; she is literally "of the people," since she embodies their pain and is the source of their hope. Activism has, in a sense, become religion in Meridian, a practice based in faith, love, and commitment..

In fact, it seems that in order for Meridian to heal physically and spiritually, she first has to become one of the people for whom she fights. Her illness has another effect in the novel, which is to make her appear one of the "impoverished, badly nourished black villagers" of Chicokema (143). She looked "as if she belonged," and, like other poor blacks, "could summon whatever energy a task that had to be performed required" (143). This energy exists as kind of a mystical force in the novel, "something her ancestors passed on from the days of slavery when there had been no such thing as a sick slave" (143). As a force, this energy compels Meridian to 
perform acts of sacrificial resistance to white power and leaves her unable to move or speak; when members of the community pick her up and carry her to the home they provide, they symbolically uphold ancestral traditions while paying homage to the history that has paved the way for Meridian's sacrifice. As energy, this history comes alive through Meridian's performances. The nature of these performances — which aim to reveal the truth of black suffering in a white supremacist nation - is similar to what Harry Elam, Jr. calls a "reality check": "a moment that traumatically ruptures the balance between the real and representational" (173). According to Elam, a reality check creates a "dissonance" and "demands that the relationship between the real and representation be renegotiated" (173). As an example, Elam discusses the funeral of Emmett Till, a black fourteen year old who was beaten, tortured, and killed by whites in 1955 in Mississippi for allegedly whistling at and talking to a white woman in a store. Elam relates how Till's mother, Mamie Mobley, insisted on a public funeral with an open casket, in which was placed a photograph of a smiling, boyish Till (contrasted gruesomely with the reality of his featureless, unrecognizable face in the casket). Elam argues that acts of performative reality such as Mobley's can disrupt the ordinary experience of reality for spectators and "can excite social action" (173) when the discrepancies between the real and representational are brought into the open.

In Meridian, reality checks are used to reveal the living conditions of blacks - especially poor Southern blacks — despite the gains of the civil rights movement. Toward the end of the novel, for example, is a description of a small black neighborhood (ostensibly in Chicokema), in which lies, behind the rows of houses, a ravine that leads into a ditch ("the pool") running the length of the street. The children are warned not to play in the ditch, since "the water in the pool could rise silently as a thief until it covered the head of a three-year-old" (194). The children 
continue to slip away, however, since white town officials shut down the segregated community pool. The officials then constructed a reservoir near the low-lying neighborhood, so when the excess water spilled over "children caught wading in the pool were knocked off their feet and drowned" (195). Every year, the neighborhood followed the same ritual of grief, taking food to the family of the dead child and cursing the town officials. Meridian's response is worth quoting in full:

It was Meridian who had led them to the mayor's office, bearing in her arms the bloated figure of a five-year-old boy who had been stuck in the sewer for two days before he was raked out with a grappling hook. The child's body was so ravaged, so grotesque, so disgusting to behold, his own mother had taken one look and refused to touch him. To the people who followed Meridian it was as if she carried a large bouquet of long-stemmed roses...they had followed her into a town meeting over which the white-haired, bespectacled mayor presided, and she had placed the child, whose body was beginning to decompose, beside his gavel. The people had turned with her and followed her out (195).

Meridian's performance, in the same spirit as Till's mother, disrupted the ordinary procession of events in the town and used the black boy's body as a reality check to expose the conditions of the black community. Moreover, the act disrupted the de facto segregation of the town by placing the black body in official white space; the mayor's authority in this moment is displaced by the grotesque sight of a decomposing black body, symbolic of the decomposition allowed in (and imposed on) the black community by the very white people in the room. When Meridian later watches workmen from the city filling in the ditch (219), the victory is not treated as a celebration, but as a reminder that there will always be more work to be done, more battles to 
fight.

\section{Internal Struggles: Personal and Racial Dynamics in the Movement}

In Going South: Jewish Women and the Civil Rights Movement, Debra Schultz describes

the antiracist tradition in Jewish culture and how female Jewish civil rights workers were "women with multiple and contradictory identities" (3). Characterizing these women as "relatively privileged" and "well educated" (3), Schultz argues that white Jewish women were often raised within a "liberal Jewish moral framework of social justice that made involvement in the civil rights movement almost irresistible" (4). Moreover, she observes how some of the women were motivated by a strong sense of resistance that accompanied stories and memories of the Jewish holocaust and also by a personal interest in discovering what it meant to be Jewish and American. The interviews documented by Schultz also reveal the barriers Jewish women encountered when they reached the South, including criticism from their families and other Jews who sought assimilation into American culture and suspicion from Southern blacks who feared the presence of a white woman in the community might bring dangerous consequences (58). In Meridian, the presence of white Jewish women is presented in much the same way, and Walker explores another, related concern also expressed by Schultz: the always-present question of black-white sexual relations and the corresponding effects on the movement.

Walker's treatment of gender and sexuality in Meridian is an attempt at understanding, as opposed to criticizing, the nature of human relationships and the complicated closeness that results from participation in a struggle. Instead of creating characters that reveal the misguided liberalism of white antiracist tradition, Walker explores the contentious racial and sexual dynamics in which white women must operate while revealing possibilities for meaningful interaction between white and black women. ${ }^{7}$ Accordingly, the white women of Meridian are no 
more flawed than Walker's black characters, and their naïveté is balanced by a very real compassion for others and a commitment to resisting cruelty and suffering. Through the relationships that exist among Meridian, Truman, and Lynn, Walker is able to highlight the tensions resulting from interracial sexual relationships and the internal struggles of her characters to cope with the social order that has produced these tensions. This is especially the case with Truman, who in a sense views Lynn as a trophy wife; through their marriage, his image of his masculinity is strengthened because he obtains something the white world denies him. On the other hand, his intellectualism alienates him from other blacks, and he longs for the authentic "blackness" he feels when with Meridian. Meridian, however, remains the key to Walker's analysis, which comments on the historical use of black women as a symbol. To Truman, she is a ticket into black belonging and cultural authenticity; for Lynn, she is a representative black woman to whom Lynn can reveal her thoughts on race and on whom she can rely on for moral support and guidance.

Through Meridian, Walker explores the dynamic process of healing that can mend relationships with the self and others. As her lifetime of work makes clear, Walker relies on a black feminist philosophy and historical black feminism to provide a moral framework and resolution to the story. Hendrickson borrows Walker's term "womanist" to describe the novel, which Hendrickson says "combines the black consciousness and feminist consciousness that grew out of the Civil Rights Movement" (113). Walker does indeed display throughout Meridian a strong feminist orientation that disrupts traditional understandings of women's roles in Western society. Meridian's struggles with motherhood, her desire for freedom, and her disinterest in maintaining committed romantic relationships with the men in her life all point to a growing feminist consciousness that aimed, at its very center, to define women first as human 
beings, and to reveal the ordinary flaws, contradictions, and, ultimately, the inherent strengths that make women and men equal members of humanity. Hendrickson further argues that the term "womanist" is used deliberately by Walker to separate her notion of black feminism with the white middle-class and intellectual feminism that either ignored or paid little attention to the specific problems faced by black women (113). As she makes clear in Everything We Love Can be Saved, however, Walker's feminism is meant not just to differentiate between black and white women's concerns, but to recover women's image from the violent patriarchy that, historically, worked to subordinate women from their original roles as community or tribal leaders. Meridian, as a community leader in Chicokema, represents one path to selfhood for Walker; as a young black woman, Meridian rejects male authority (without rejecting male companionship), revises cultural understandings of black womanhood, "comes to life" as a civil rights activist, and is eventually healed — both physically and spiritually—by her commitment to the community. Meridian's activism is complex; it is born out of her love for black people as well her guilt about her shortcomings as a mother and daughter. This contradiction (Meridian is both selfless and self-obsessed) points to a subtle criticism about the civil rights movement in the novel which is also a dominant theme in Walker's entire oeuvre: the lack of self-love (not to be confused with ego) as the fundamental wedge between the self and the world. This understanding is influenced, no doubt, by the ministry of Martin Luther King and his belief that love for oneself would translate into love for those outside of oneself. ${ }^{8}$ Meridian's guilt over her abandonment of her son, which Lindsey Tucker argues represents a choice between "mobility and maternity" (2), is rooted in her image of her mother as the perfect representative of black womanhood: clean, pious, and hardworking. Meridian's teenage pregnancy, her choice to give 
up her son to attend college, and her decision to protest in the streets instead of testify in the church mark her as unworthy (in her own eyes) of the legacy of her mother.

The conflict between Meridian and her mother also underscores the generational discord within black communities resulting from civil rights protests. In the 1960s, particularly older black people were hesitant to acknowledge or participate in civil rights activities (just as there were some rural black people who knew little about the movement at all). For many, including Meridian's mother, the strength of black communities was derived from participation in those institutions - marriage, family, church, school — that were historically denied them. However, as Tucker observes, "the result of Meridian's responsiveness to the voice of her mother is immobilizing illness — nightmares, headaches, anorexia, temporary blindness, but especially paralysis and a kind of catatonia" (5). It is clear from Meridian's self-induced neurosis that each protest, which represents a further step away from her mother, is a kind of death, a killing off of the daughter-mother figure that she had been earlier in the novel. At the same time, the nature of her illness is also symbolic; to reject her mother is also to reject inaction and complacency in the creation of a new narrative of radical black womanhood. This dynamic in Meridian represents the difference between what Danielson calls the "conventional" and "critical" aspects of the novel: the conventional story is that of a quest novel, with the backdrop of civil rights organizing providing a context for Meridian's personal growth, while the critical nature of Walker's writing "sets new values against old ones" (317-18). In the choice between "mobility and maternity," black and white women have historically been expected to choose and surrender to maternity. This dichotomy is not complete, however, unless one realizes that by choosing mobility, Meridian also chooses to fight for the future of the child she gave up. Her maternity informs her struggle and recasts black mothers as potential revolutionary figures. 
Walker infuses Meridian with power that comes both from her femininity and from the spiritual strength resulting from her activism. These strengths, in the novel and in Walker's other work, are inextricably linked to the notion of heritage; Walker's celebration of black women in all their complexity, along with her deep understanding of black women's history (a significant portion of which comes from her consistent explorations into her own family's past), drives her portrayal of her female characters as revolutionaries-by-default. Meridian, despite her own mother's traditionalist viewpoints regarding black motherhood, draws courage and resistance as part of a genealogy that has, since its very beginning in the New World, always been in a position of necessary resistance in order to survive. ${ }^{9}$ This position leads Walker, through Meridian, to discuss one of the more contentious dynamics of the civil rights movement: blacks and whites working together as equals to fight oppression. In the novel, Walker posits that, in addition to the patriarchy that has dethroned woman from her rightful place as community and spiritual leader, the deeply entrenched racism in the US has further alienated black women from fully participating the communities they rightfully deserve to lead.

At the center of Meridian's portrayal of black and white women is a cultural divide that can inhibit communication across racial lines. Meridian cannot remember her mother saying anything specific about white women, except that they were "helpless creatures, lazy and without ingenuity" (104). Her grandmother, however, held much stronger opinions: "1. She had never known a white woman she liked after the age of twelve. 2 . White women were useless except as baby machines which would continue to produce little white people who would grow up to oppress her. 3. Without servants all of them would live in pigsties" (105). Meridian observes how white girls "sank into permanent oblivion" after leaving school and becoming mothers and concludes that they don't do anything interesting in their adult lives (105). On the other hand, 
Meridian thinks, "black women were always imitating Harriet Tubman — escaping to be something unheard of" (105). Meridian draws strength from black women, and "it thrilled her to think she belonged to the people who produced Harriet Tubman, the only American woman who'd led troops in battle" (105). Importantly, Meridian only realizes these connections after she rejects Eddie, their baby, and the traditional course her mother had set for her. This realization, moreover, further separates black women from white women in Meridian's mind, since she sees nothing to envy about white women's married lives; Meridian's journey thus begins with the acknowledgment that to be a black woman in America is to be part of something spectacular. Meridian's friendship with Lynn showcases the hardships faced by black and white women resulting from patriarchal and racist traditions. While she is still at Saxon, Meridian tells Truman about three young Jewish women who are exchange students at the college. Lynn is among these women, and quickly forms a friendship with Meridian while they are out canvassing voters among the mostly elderly blacks in rural towns. The cultural divide is immediately noticeable, however, when one elderly woman invites the two in for a meal, telling them she doesn't believe in voting because "the Good Lord He take care of most of my problems" (98). Lynn argues with Mrs. Turner, using what Meridian refers to as "Northern logic" when Lynn responds, "So God fixes the road in front of your house, does he?" (98). Meridian, having grown up accustomed to the reverence with which many older blacks practiced Christianity, recognized that Mrs. Turner's faith could not be budged, whereas Lynn's "Northern" intellectual arguments assumed that logic trumped faith. When Mrs. Turner tells Lynn, "You sound like maybe you is kin to Judas Iscariot" (98), she signals the distrust that generations of segregation and racism have fomented in black-white relationships. In moments like the above, when that distrust is acknowledged out loud, Walker shows the precarious nature 
of interracial coalitions in a nation that throughout its history discouraged, condemned, and punished such closeness between races.

By placing Meridian as part of a love triangle with Truman and Lynn, Walker comments on the racial and sexual dynamics that can accompany socials movements in which men and women work closely together for long hours and rely on each other for emotional support. The sections involving the three also reveal Walker's ideas about black masculinity within the context of a US history that saw the violent denial of relationships between black men and white women and the (sometimes public) display of the black female body for white male consumption. Walker seems to argue that the civil rights movement, especially in areas of high interracial cooperation, afforded black men the chance to rebuke white authority by becoming sexually involved with white women. In Truman's case, however, his relationship with Lynn suffers because of an overwhelming need to be "authentically" black, which would require that he be involved with a black woman-Meridian —in order to preserve his blackness. Meridian, caught in the middle, experiences the hurt of generations of black women who were made to feel inferior to white women. After Meridian and Truman's first sexual encounter, for example, Meridian is on her way across campus to have an abortion (Truman, who left after having sex with Meridian, is ignorant of her pregnancy) and spies Truman with Lynn in his father's new car. What follows is a description of Meridian's feelings of hurt and betrayal that connect her to the suffering of black women who are made to feel ashamed of their blackness: "From a distance, they both looked white to her. Later, as the doctor tore into her body without giving her anesthesia (and while he lectured her on her morals) and she saw stars because of the pain, she was still seeing them laughing, carefree, together" (112, my emphasis). 
In this section, Truman has become white, at least to Meridian; his casual (and arrogant) sliding into French language with Meridian, who knows little French, is now seen as part of a larger attempt to shed his blackness by becoming superior to other black people. When Truman tells Meridian shortly after her abortion, "I think I'm in love with you, African woman... have my beautiful black babies," she hits him multiple times, drawing blood before turning her back and walking away (113). In Meridian's rejection of Truman, Walker criticizes not interracial relationships, but the use of women as symbolic objects; Truman's patriarchal attempt to define Meridian in his own image of her, as an "African woman," is contested by Meridian, whose masculine use of violence stuns Truman and upsets the dynamics of power between black women and men. This rupture leads to a separation between Meridian and Truman, who returns to and eventually marries Lynn.

Through the lens of the civil rights movement, Meridian questions whether the relationships between black men and women can be repaired. The damage done to black men's sense of masculinity by a white racism that alternately defined black men in terms of savagery, femininity, and childishness is presented alongside the history of black women whose reproductive rights were controlled by white men in slavery and who also sometimes suffered, after slavery, at the hands of black men who sought to restore their own masculinity through emulating white patriarchal authority. Truman's struggles with his feelings of inadequacy could, in fact, be Walker's way of arguing that healthy masculinity is not mediated through relationships with women, but is instead cultivated through a loving relationship with the self that is then directed outward in relationships with others. It is Meridian's unwillingness to serve as "proof" of Truman's blackness that, in the novel, represents the troubled relationships between black men and women; in attempting to "own" Meridian, to wear her as an accessory to 
his blackness, Truman is guilty of the centuries-old practice by which blacks were considered in terms of their usefulness instead of their humanity. The civil rights movement, when considered from a black feminist perspective, could not be successful unless it insisted on the equal status of African Americans in US society and the full and necessary privileges owed especially to black women.

The remainder of the love triangle narrative is as troubling as it is revealing in terms of what it says about Walker's views concerning interracial relationships and the future of race relations in the US. While Meridian is on a spiritual journey of self-discovery and grassroots activism, Lynn and Truman's story turns into a tragedy. Because "To Lynn, the black people of the South were Art" (128), she and Truman arrive in Mississippi two years after the murders of Cheney, Goodman, and Schwerner. Truman is fed up with the movement, but Lynn wants to experience the pain of Southern blacks, to see them at their most destitute, despite her motives bordering more on a white, Northern curiosity about black life rather than a dedication to social justice. Her naïve white liberal mindset is met, however, with the violence of the South; when their friend Tommy Odds loses part of his arm after being shot coming out a black church, Odds places the blame on the closest white person: Lynn. Thinking that the attack might have been motivated in part by revenge in a community that considered white women "whores" if they associated with black men, Odds concludes, "All white people are motherfuckers...I want to see them destroyed" (130). Later, Odds rapes Lynn, who "by being white... was guilty of whiteness" (131), and who, to black men in the South, was "a route to Death, pure and simple" (134). Odds's rape of Lynn is a pitiful attempt to reverse this power of death; motivated by rage and resentment, his betrayal of Lynn is complicated by her inability to resist. When she forgives him for raping her, he returns the next day with more of their friends, urging them to do the same. 
They refuse, although they offer Lynn no comfort, and even Truman does not exact revenge on Odds, choosing instead to let his relationship with Lynn deteriorate until she begins sleeping with black men out of guilt and enjoying the "misguided rage" of the black women who hate and sometimes attack her (167). The theme of violence is continued later when Lynn and Truman's six-year-old daughter, Camara, is raped and murdered, causing both to seek out Meridian for guidance and for advice on how to cope with their loss.

The love triangle narrative reveals Walker's preoccupation with loss, healing, and the ability of human beings to recover from unthinkable pain and suffering through love. Despite the overriding sense of doom that prevails through Meridian's abortion and the violent death of Camara, the death of children in Meridian points to the necessity of struggle in the most dire circumstances, even when hope seems futile. Readers will remember, for instance, that Meridian chose to fight instead of give in to her early fantasies of killing her first child. Through a reconciliation of sorts between the three characters, Walker expresses the nature and power of love to combat the darkness of the world. For Lynn and Truman, "it was Meridian they both needed, and it was Meridian who was, miraculously, there" (175). She spends time between their apartments and even resorts to sleeping in bed with Lynn, "who held on to her like a child afraid of the dark" (175). Her feelings for Truman return, but they are importantly non-sexual: "It was love totally free of possessiveness or contempt. It was love that purged all thought of blame from her too accurate memory. It was forgiveness" (175). With Lynn, "the absence of the child herself was what had finally brought them together," as they both grieved the loss of children (177). In the end, Meridian's activism is expressed most eloquently in her unconditional love for people, regardless of race, and this love is embedded into the novel as a whole. The most important 
lesson life teaches us, Walker suggests, is to not lose trust in each other or lose hope in humanity, because the alternative only leads to despair and death.

\section{Conclusion: Transformation and Redemption}

In one of the novel's most memorable and important scenes, Lynn and Truman stand arguing outside Meridian's house and Meridian, who goes wandering around the neighborhood, decides her own fate: “"The only thing now,"” she says out loud as people stare, "“would be the refusal of Christ to accept crucifixion. King...should have refused. Malcolm, too, should have refused. All those characters in all those novels that require death to end the book should refuse. All saints should walk away" (150-51). To the question of whether or not revolutionary violence is a legitimate form of resistance to cruelty and oppression, Meridian's thoughts answer a resounding "no." A refusal to see death (or martyrdom) as glorious is at the center of the novel's politics; whereas Christ, King, and Malcolm X became ultimate symbols of martyrdom, their deaths remain significant only because of the symbolism attached to them. We should all, the novel suggests, celebrate life instead and choose to honor the lives of the dead by committing ourselves to the fight they began. Moreover, by purposefully conflating fact and fiction, life and literature, Walker makes clear how the two are related. Jesus, to be sure, is a hero in literature and in history, and Walker attempts to reveal the ways in which literature can help us to empathize with and learn from representative figures, whether or not they actually exist. Meridian shows how the legacy of a life — whether on the page or in reality—is in the effect it has on people: how it leads them to ask questions, to consider a change in perception, or even to participate in the worldview or behavior that is represented through characters and events.

This legacy is displayed in the novel as Meridian stands with other poor blacks outside a church in downtown Atlanta on the day of Martin Luther King's funeral: 
The nearby families told their children stories about the old days before black people marched, before black people voted, before they could allow their anger or even their exhaustion to show. There were stories, too, of Southern hunts for coons and 'possums among the red Georgia hills, and myths of strong women and men, Indian and Black, who knew the secret places of the land and refused to be pried from them. As always they were dressed in their very Sunday best, and were resigned; on their arms the black bands of crepe might have been made of iron (189).

As Meridian stands among the "pitiable crowd of nobodies who hungered to be nearer" (190) as politicians and celebrities begin to fill the church, Walker gives readers a vision of King's beloved community. Combining history with the present, fact with fiction, and myth with reality, the above scene speaks to the connections that form our shared existence on the earth and to the memories that sustain us in times of darkness. Walker also contends that this form of community is a distinctive characteristic of black and Indian people; at the march following the funeral, for instance, a young black boy tells a white couple, "We don't go on over death the way whiteys do" (190). King, now dead, is immortalized in black folk history as a leader who brought about significant change to the way black people lived. Though his physical presence is gone, it is the often intangible effects of King's life that are celebrated in Meridian: the hope he gave to black communities, the self-respect he urged in black people, the love he gave to them, and the love he fostered in others.

When Meridian begins attending a black church again toward the end of the novel, the impact of King's life is evident in the consciousness of everyone present. As she listens to the preacher, "it struck Meridian that he was deliberately imitating King, that he and congregation 
knew he was consciously keeping that voice alive...not his own voice at all, but rather the voice of millions who could no longer speak" (200, emphasis in original). King's voice, physically present in the church, remains a marker of black belonging and protest in the community; his voice, accordingly, is his gift to humanity, an ever-present ghost in the collective conscience that urges love before hate and understanding as opposed to violence. It is the voice Meridian hears when she rejects the call to revolutionary violence when, seated with Truman and others talking about the ethical and political nature of killing, she declares, "revolution would not begin, do you think, with an act of murder — wars might begin that way—but with teaching" (192). The novel, as a teacher, involves readers in the thought processes that go into planning, organizing, and participating in revolution. It also cautions that revolution "like everything else in America, was reduced to a fad...the leaders were killed, the restless young were bought off with anti-poverty jobs, and the clothing styles of the poor were copied by Seventh Avenue" (193). In the end, Meridian retreats, as does the novel itself, back into the people, the "pitiable crowd of nobodies" who form the heart of the beloved community.

Ultimately, Meridian's recovery comes in the form of the very people she sought to help, those who, although they struggle against poverty, illness, violence, and death, have learned to survive and even thrive in the communities they've built. While in church, Meridian discovers that the church itself (not the building, but the spiritual community) in "the music, the form of worship that has always sustained us" are the "ways to transformation" that are the secret of black survival in the US. When this realization hits, "there was in Meridian's chest a breaking as if a tight string binding her lungs had given way, allowing her to breath freely" (204). She learns, at the end of her journey, that "the respect she owed to her life was to continue, against whatever obstacles, to live it, and not to give up any particle of it without a fight to the death" (204). This 
understanding leads her to admit that she would in fact be able to kill, but only if by killing she could preserve the life of black people, the "existence that extended beyond herself" that had created in African Americans "One Life."

Like Johnson in Dreamer, Walker wrote Meridian in part as a response to the "spiritual degeneration" (Meridian 88) that began, for some, with the death of Martin Luther King. She calls on the legacy of African-America, which survived generations of kidnappings, slavery, terrorism, lynchings, bombings, police brutality, segregation, and the dangers of living in a racist culture without the protection of the law or the courts. As Meridian declares, the "respect" that African Americans owe their lives, and the lives of their ancestors, is to continue in the tradition of those who fought for their existence and to keep alive the voices of those who spoke in defense of their freedom. Love, as the revolutionary emotion, reaches out to readers of the sixties generation and those who came after to encourage faith in humanity and an active, conscious resistance to the cruelty that sometimes shakes that faith to its very foundations. Walker reminds us that texts speak to us and contain within them the power to transform our thinking; through her characters, she imagines a world much like our own but with a specific, focused attention on the mystical, intangible qualities of life that make it worth living. Meridian asks each of us to consider the price we must pay for our lives and those of the people we love, as well as the lengths to which we will go to preserve the dignity of all life in a world that can seem impersonal and, especially to some, even threatening. Walker's philosophy fills the pages of Meridian and confirms that the practical use of literature is in its abilities to guide us, however fleetingly, toward a better understanding of the world and ourselves. 


\section{Notes}

${ }^{1}$ Space restraints keep me from a more thorough and complex analysis of African American feminism in the period following the 1960s. The authors I choose to discuss are representative of one group of African American feminists who wrote about the 1960s and consciously incorporated the ideas, events, and spirit of the decade into their work. I also chose to discuss writers who are not always positioned in relation to the sixties and therefore did not include extensive analysis of such women as Toni Cade Bambara, Angela Davis, Elaine Brown, and Assata Shakur. For an excellent resource on the latter three which also includes material from Bambara, see Perkins.

${ }^{2}$ It is important to note that Deadwyler and his pregnant wife were traveling to the nearest county hospital, which was twenty miles away. Much like in Charles Johnson's Dreamer (see previous chapter), in which black mortality was heightened because of a lack of access to a nearby hospital, the absence of hospitals in black communities was a determining factor in both Deadwyler's death and in the subsequent riots.

${ }^{3}$ For more on black masculinity and homophobia, see bell hooks, We Real Cool; Mutua; and Douglas. Douglas notes how whites often perceive black communities—especially black males - to be "hyperhomophobic" (997). She argues that this is a misrepresentation caused by a historic, racist perception of blacks' hyper-sexualized nature perpetuated in the modern age. She cites white televangelists such as Jerry Falwell as being the most vocal anti-gay members of society while also acknowledging that the pervasive silence concerning homophobia in black communities is a problem that must be addressed (997). 
${ }^{4}$ For an excellent, interdisciplinary resource on the Black Panther Party, see Lazerow and Williams.

${ }^{5}$ For more on Walker's arrest and Code Pink, see Cockburn, 62-66.

${ }^{6}$ Meridian's critique of traditional roles for black women is similar in nature to critiques of the "containment narratives" of US citizenship and domesticity, seen particularly in times of crisis such as the Cold War. For a discussion of this in relation to Don DeLillo's novel Libra (1988), see chapter 3.

${ }^{7}$ For an excellent source on early black feminism aside from what I've listed in this chapter, see Collins, Black Feminist Thought. For a discussion of white liberal hypocrisy, see Cone, Black Theology and Black Power.

${ }^{8}$ King expressed these ideas most eloquently in his collection of sermons Strength to Love. New York: Harper and Row, 1963. In the sermon “Antidotes for Fear," King discusses his notion of "self-affirmation," which he defines as a "proper self-love and a properly positioned love of others" (118). This self-affirmation is King's "antidote" to fear, since it situates one within his idea of a beloved community that bestows strength upon those who love themselves by giving themselves to others.

${ }^{9}$ For history on black women's activism, see Dandridge; Yee; Perkins; and Robnett. 


\section{Conclusion:}

\section{Long Time Gone: Literature, Life, and Activism after the 1960s}

If there is one thing we can learn from the $60 \mathrm{~s}$, it is how infinitely complex any move for liberation must be...through examining the combination of our triumphs and errors, we can examine the dangers of an incomplete vision.

- Audre Lorde, Sister Outsider $[\mathrm{M}]$ any aspects of the future course of Occupy Wall Street remain unclear. But one thing is starkly evident: Under the banner "We are the $99 \%$ ", the protest has given birth to America's most important progressive movement since the civil rights marches half a century ago.

— Writers for the 99\%, Occupying Wall Street: The Inside Story of an Action that

Changed America

Kenton Rambsy, writing for the Project on the History of Black Writing at the University of Kansas, points to this scene in Ralph Ellison's Invisible Man as an example of the tradition of social protest in African American novels:

In chapter 13 of Invisible Man, the unnamed narrator happens upon a growing crowd that is witnessing an eviction of an elderly couple from their Harlem apartment. After becoming so disgusted with the treatment of the couple and beginning to question how the affluent property owners could treat tenants as such, the Invisible Man delivers a very powerful impromptu speech that rouses the crowd and leads them to carry the couple's belongings back into their apartment. This scene begins Invisible Man's association with the Brotherhood and other acts of organized resistance (n.p.). 
Rambsy writes of the above, "long before the actualization of the Poor People's Campaign....and Occupy Wall Street protests, Invisible Man seizes upon and explores the challenges and opportunities of organized resistance tactics" (n.p.). The ability of literature to capture the spirit of protest and to encourage such protest is not a recent phenomenon; as early as the American Revolution, Thomas Paine's pamphlet Common Sense was inspiring readers to resist tyranny and fight for freedom. The abolition movement in the mid- $19^{\text {th }}$ century US was similarly fueled in part by the literature-slave narratives, Harriet Beecher Stowe's Uncle Tom's Cabin, and countless pamphlets on the evils of slavery - that condemned the institution of slavery in the "land of the free." The nation's most prized document, The Declaration of Independence, plainly declares that America must be a revolutionary nation, ready at any moment to resist oppressive government practices that undermine the freedoms of the people.

Still, things have improved little since Ellison wrote his masterpiece; the 2008 US financial crisis, caused in large part by predatory lending practices by the nation's largest banks has, at the time of this writing, led to the foreclosure of over two million homes in the United States. Unsurprisingly, these foreclosures have disproportionately affected poor people and people of color. Additionally, according to a report by Bloomberg Markets Magazine, the 700 billion dollar TARP (Troubled Asset Relief Program) bailout approved by the federal government in 2008 to rescue financial institutions from bankruptcy was, in fact, only the publicized portion of the package — the federal government supplied somewhere close to 7.7 trillion dollars in secret loans to the same institutions, which used those loans not to lend money to people in financial trouble, but to reap large profits and continue with business as usual ("The Federal Reserve's" n.p.). It is out of such a culture that the Occupy Wall Street movement was born. Committed to being the voice of "the 99\%", OWS has relied on tactics reminiscent of 
1960s activism, such as teach-ins, occupations (as in the 1967 March on the Pentagon), and sitins at college campuses around the nation. OWS's governing philosophy also sounds like a throwback from the sixties era: "principles of direct democracy, consensus-based decision making, inclusiveness, and transparency" (Occupying 2). As the voice of the people, OWS has become an international movement—influenced significantly by the "Arab Spring" protests that have, as of this writing, ousted leaders in Tunisia, Egypt, Libya, and Yemen-invested in expressing "outrage with the inequities of unfettered global capitalism" (Occupying 5). In an age of popular protest around the world, the global reach of capitalist expansion and oppression has become the focus for those who wish to upset the ways in which power is entrenched among wealthy elite, ruling classes.

However noble such attempts are, however, they operate within nations that have seen revolutions before. To take the US as an example, the landmark legislation against segregation and discrimination that came out of the 1950s and 60s has allowed for the rise of a black middle class and a black elite that, at the academic level, has worked alongside others to reveal the inner workings of racism and race-based privilege and how they have structured the social, economic, and political fabric of American life. One might think that race-exposed as a marker of cultural distinction but not of genetic disposition —-would no longer matter in contemporary social relations; however, as a former black student of mine who uses her middle name instead of her "black-sounding" first name on job applications told me, "as soon as I sounded white on paper, I started getting calls for interview that I never got before." Furthermore, scholars like Houston Baker, Jr. are not convinced that access to privilege is necessarily a good thing; in Betrayal: How Black Intellectuals Have Abandoned the Ideals of the Civil Rights Era (2008), Baker argues that "in America, it is fashionable to decry any felt, perceived, or stated need for a leader or leaders 
for the black community," a sentiment he ascribes to "white neoconservatism's ascendance and influence" (72). Neoconservatism, loosely described as a set of socioeconomic and political principles by which global systems of capital — with government complicity but within a nonregulatory, free-market ideology—create and perpetuate wealth within ever-smaller elite groups of people, depends upon this type of apathy; a depoliticized and distracted populace (evidenced by Americans' obsession with technology, for instance) is difficult to organize and mobilize.

The perceived need for resistance is often met with a hesitancy to disrupt the status quo and a fear of the unknown. As Barack Obama's campaign and presidency has shown, Americans still fear the racial "other" as a potentially subversive, revolutionary figure, even as questions pertaining to Obama's religion and nationality were thought put to rest. In fact, Obama's presidency has been defined by business-as-usual politics in the ways he has reserved federal power for the same circle of politicians, bankers, businesspeople, and lobbyists that encouraged many to vote for what they thought would be a revolutionary president. As Noam Chomsky observes, "in a democracy, the governed have the right to consent, but nothing more than that" (44). Democracy is thus the embodiment of a false consciousness, and emblem of a society of choice in which the decisions made by the masses affect only who is in charge at any given moment, not the system itself. As I noted with my reference to Paul Connerton in the introduction, revolutionary moments pull back the curtain on the system; race riots, authoritarian violence, and war in Vietnam in the 1960s mobilized people, as the economic crisis does as I write this. The question now becomes what to do with this revolutionary moment. It is hard not to admit that a nation in which millions are jobless and have lost their homes is in a crisis and that those in charge have caused and exacerbated that crisis. What now? Baker insists that "we must forge connections (secular and sacred)...[and] seek to lead our students, colleagues, 
administrators, and local community participants to understand the costs of globalization" (216). Just what are these costs, and how can we work to prevent them? How do we move forward to ensure that political action is realizable at street level for those whose voices go, if not unheard, unheeded by those in power?

In this study, I have proposed that one way to move forward is through uncovering and promoting the moments in texts that remember, critique, and celebrate popular resistance while encouraging and instructing readers to participate in movements at any level to benefit their communities. I have chosen to focus on American literature that concerns the 1960s or that has been influenced by the decade because the American 1960s can serve as a textbook or case study for resistance. Throughout, I have attempted to show how literature can imaginatively connect readers to activist figures and movements that can inspire them to better understand the need for social activism and, maybe, to take action themselves. Some literature, as in the previous chapter, documents the processes by which coalitions such as the ones Baker calls for are formed. At the very least, I hope this project and others like it will inspire discussion —in the classroom, in the academy, in the street—about how literature can make us more emotionally intelligent and more aware of the need for compassion in the world. The specific texts I've studied do this, I think, and more; by critically questioning the idealism of social movements in an increasingly global culture, they anticipate the neoliberal, capitalist monolith that turns idealism into cynicism, hope into despair. The cautious optimism of the authors presented here is a moral as well as a strategic positioning — without the hope of a brighter future, the "long twilight struggle" of Kennedy's inaugural address will be a losing battle. The power of literature is to imagine worlds much like our own, only better; the power of the people is to help make them reality. 
Works Cited

“A Shaky Start.” Time.com. 27 October 1967. Web. 2 September 2011.

Adams, Rachel. "The Ends of America, the Ends of Postmodernism." Twentieth-Century Literature 53.3 (2007): 248-72. Print.

Alderman, Derek. "Street Names as Memorial Arenas: The Reputational Politics of Commemorating Martin Luther King Jr. in a Georgia County.” Eds. Renee C. Romano and Leigh Raiford. The Civil Rights Movement in American Memory. Athens: The University of Georgia Press, 2006. Print.

Ammons, Elizabeth. Brave New Words: How Literature Will Save the Planet. Iowa City: University of Iowa Press, 2010. Print.

Anderson, Benedict. Imagined Communities. New York: Verso, 1983. Print.

Anderson, Terry H. The Movement and the Sixties: Protest in America From Greensboro to Wounded Knee. New York: Oxford UP, 1995. Print.

Awkward, Michael. Negotiating Difference: Race, Gender, and the Politics of Positionality. Chicago and London: University of Chicago Press, 1995. Print.

Baker, Houston A. Betrayal: How Black Intellectuals Have Abandoned the Ideals of the Civil Rights Era. New York: Columbia University Press, 2008. Print.

Baldwin, James. The Fire Next Time. 1963. New York: Vintage, 1993. Print.

Baldwin, Kate. "Between Mother and History: Jean Stafford, Marguerite Oswald, and US Cold War Women's Citizenship." Differences 13.3 (2003): 83-120. Print.

Bambara, Toni Cade, ed. The Black Woman: An Anthology. NY: Washington Square Press, 1970. Print.

Barthes, Roland and Stephen Heath. Image, Music, Text. New York: Hill and Wang, 1977. Print. 
Baudrillard, Jean, Interview. "I Don't Belong to the Club, to the Seraglio." Baudrillard Live: Selected Interviews. Ed. Mike Gane. NY: Routledge, 1993.

Bauman, Zygmunt. Liquid Times: Living in an Age of Uncertainty. Malden, MA: Polity Press, 2007. Print.

---. Postmodern Ethics. Malden, MA: Blackwell, 1993. Print.

Berger, James. After the End: Representations of Post-Apocalypse. Minneapolis: University of Minnesota Press, 1999. Print.

Berlant, Lauren. The Queen of America Goes to Washington City: Essays on Sex and Citizenship. Durham, NC: Duke UP, 1997. Print.

Bloom, Harold. Alice Walker. Broomall, PA: Chelsea House, 2002. Print.

Booth, Wayne. "Why Ethical Criticism Can Never Be Simple." Ethics, Literature, Theory: An Introductory Reader. Ed. Stephen K. George. Lanham, MD: Roman and Littlefield, 2005. Print.

Boym, Svetlana. The Future of Nostalgia. NY: Basic Books, 2001. Print.

Braudy, Leo, ed. Norman Mailer: A Collection of Critical Essays. Englewood Cliffs, NJ: Prentice Hall, 1972. Print.

Bugliosi, Vincent. Reclaiming History: The Assassination of President John F. Kennedy. New York: W.W. Norton and Company, 2007. Print.

Busch, Andrew. Ronald Reagan and the Politics of Freedom. New York: Rowman and Littlefield, 2001. Print.

Byrd, Rudolph P. Charles Johnson's Novels: Writing the American Palimpsest. Bloomington: Indiana UP, 2005. Print.

Chambers, Judith. Thomas Pynchon. New York: Macmillan, 1992. Print. 
Chandaraplaty, Raj. The Beat Generation and Counterculture: Paul Bowles, William S. Burroughs, Jack Kerouac. New York: Peter Lang, 2009. Print.

Chepesiuk, Ron. Sixties Radicals Then and Now: Candid Conversations with Those Who Shaped the Era. Jefferson, NC: McFarland, 1995. Print.

Christian, Barbara. "'Somebody Forgot to Tell Somebody Something': African-American Women's Historical Novels.” New Black Feminist Criticism, 1985-2000. Ed. Gloria Bowles, et al. Champaign: University of Illinois Press, 2007. Print.

Chomsky, Noam. Profit Over People: Neoliberalism and Global Order. NY: Seven Stories Press, 1999. Print.

Chong, Dennis. Collective Action and the Civil Rights Movement. Chicago: The University of Chicago Press, 1991. Print.

Cockburn, Alexander. "Mother of the Decade.” Texas Monthly 1.10 (1971): 79-80. Print.

Cockburn, Cynthia. From Where We Stand: War, Women's Activism, and Feminist Analysis. London: Zed Books, 2007. Print.

Collins, Patricia Hill. Black Feminist Thought: Knowledge, Consciousness, and the Politics of Empowerment. New York: Routledge, 1991. Print.

---. Fighting Words: Black Women and the Search for Justice. Minneapolis: University of Minnesota Press, 1998. Print.

Cone, James H. A Black Theology of Liberation. 1969. Maryknoll, NY: Orbis Books, 2010. Print.

---. Black Theology and Black Power. New York: Seabury Press, 1969. Print.

Connerton, Paul. How Modernity Forgets. Cambridge and NY: Cambridge UP, 2009. Print.

---. How Societies Remember. Cambridge and NY: Cambridge UP, 1989. Print. 
Connolly, Kevin. “An Interview with Don DeLillo.” Conversations with Don DeLillo. Ed. Thomas DePietro. Jackson: University of Mississippi Press, 2005. Print.

Cowan, Michael. "The Americanness of Norman Mailer." Norman Mailer: A Collection of Critical Essays. Ed. Leo Braudy. Englewood Cliffs, NJ: Prentice-Hall, 1972. Print.

Cowart, David. "Attenuated Postmodernism: Pynchon's Vineland." Critique 32.2 (1990): 67-76. Print.

---. Don DeLillo: The Physics of Language. Athens: The University of Georgia Press, 2002. Print.

Dandridge, Rita P. Black Women's Activism: Reading African American Women's Historical Romances. New York: Peter Lang, 2004. Print.

Danielson, Susan. “Alice Walker's Meridian, Feminism, and the 'Movement'." Women's Studies 16 (1989): 317-30. Print.

Davis, Angela Y. Women, Race, and Class. New York: Vintage, 1983. Print.

DeLillo, Don. Libra. New York: Viking, 1988. Print.

Dewey, Joseph. Beyond Grief and Nothing: A Reading of Don DeLillo. Columbia: The University of South Carolina Press, 2006. Print.

Douglas, Kelly Brown. "Homophobia and Heterosexism in the Black Church and Community." African American Religious Thought: An Anthology. Eds. Cornel West and Eddie Glaude, Jr. Louisville KY: Westminster John Knox Press, 2003. Print.

Dubey, Madhu. Signs and Cities: Black Literary Postmodernism. Chicago: University of Chicago press, 2003. Print.

Dussere, Erik. "'Flirters, Deserters, Wimps, and Pimps': Thomas Pynchon's Two Americas." Contemporary Literature 51.3 (2010): 565-595. Print. 
Dwyer, Owen J. "Interpreting the Civil Rights Movement: Contradiction, Confirmation, and the Cultural Landscape." The Civil Rights Movement in American Memory. Eds. Leigh Raiford and Renee C. Romano. Athens: The University of Georgia Press, 2006. Print. Elam, Harry. "Reality." Critical Theory and Performance. Eds. Janelle G. Reinelt and Joseph Roach. Ann Arbor: University of Michigan Press, 2007. Print.

Ellison, Ralph. Shadow and Act. 1964. New York: Vintage, 1995. Print.

Ellsberg, Daniel. Secrets: A Memoir of Vietnam and the Pentagon Papers. New York: Penguin, 2003. Print.

Ernest, John. Chaotic Justice: Re-thinking African American Literary History. Chapel Hill: UNC Press, 2010. Print.

---. Liberation Historiography: African American Writers and the Challenge of History, 17941861. Chapel Hill: University of North Carolina Press, 2004. Print.

Fabre, Genevieve and Robert O'Meally. History and Memory in African American Culture. NY: Oxford UP, 1994. Print.

Faith, Karlene. The Long Prison Journey of Leslie Van Houten: Life Beyond the Cult. Lebanon, NH: The University Press of New England, 2001. Print.

Farber, David. The Age of Great Dreams: America in the 1960s. New York: Hill and Wang, 1994. Print.

Fitzgerald, F. Scott. “The Crack-Up.” 1936. Esquire. Web. 12 August 2011.

Foucault, Michel and Donald F. Bouchard, Ed. Language, Counter-Memory, Practice: Selected Essays and Interviews by Michel Foucault. Ithaca: Cornell UP, 1980. Print.

Friedman, John S. The Secret Histories: Hidden Truths that Challenged the Past and Changed the Future. NY: Picador, 2005. Print. 
Garber, Marjorie. A Manifesto for Literary Studies. Seattle: University of Washington Press, 2003. Print.

Gregory, Marshall. "Ethical Criticism: What It Is and Why It Matters.” Ethics, Literature, and Theory: An Introductory Reader. Ed. Stephen K. George. Lanham, MD: Rowman and Littlefield, 2005. Print.

Gross, Ariela. What Blood Won't Tell: A History of Race on Trial in America. Cambridge, MA: Harvard UP, 2008. Print

Hall, Stuart. “An Interview with Stuart Hall.” Ed. Lawrence Grossberg. Journal of Communication Inquiry 10.2 (1986): 45-60. Print.

Hamilton, Paula and Linda Shopes, eds. Oral History and Public Memory. Philadelphia: Temple UP, 2008. Print.

Hartman, Saidiya. Scenes of Subjection: Terror, Slavery, and Self-Making in Nineteenth-Century America. New York: Oxford UP, 1997. Print.

Hassan, Ihab Habib. The Dismemberment of Orpheus: Toward a Postmodern Literature. Madison, WI: University of Wisconsin Press, 1982. Print.

Hayles, N. Katherine. "'Who Was Saved?' Families, Snitches, and Recuperation in Pynchon's Vineland." Critique 32.2 (1990): 77-91. Print.

Hendrickson, Roberta M. "Remembering the Dream: Alice Walker, Meridian, and the Civil Rights Movement.” Melus 24.3 (1999): 111-28. Print.

Hilliard, Robert L. Media Education, and America's Counter-Culture Revolution: Lost and Found Opportunities for Media Impact on Education, Gender, Race, and the Arts. New York: Greenwood, 2001. Print. 
Hogue, W. Lawrence. Postmodern American Literature and Its Other. Champaign, IL: University of Illinois Press, 2009. Print.

hooks, bell. Yearning: Race, Gender, and Cultural Studies. Cambridge, MA: South End Press, 1990. Print.

---. Teaching to Transgress: Education as the Practice of Freedom. NY: Routledge, 1994. Print.

---. We Real Cool: Black Men and Masculinity. New York: Routledge, 2004. Print.

Hume, Kathryn. American Dream, American Nightmare: Fiction Since 1960. Champaign, IL: University of Illinois Press, 2000. Print.

Hutcheon, Linda. A Poetics of Postmodernism: History, Theory, Fiction. New York: Routledge, 1988. Print.

“Investigations: Between Two Fires.” Time. 14 Feb. 1964. Web. 25 Nov. 2010.

James, Joy. Transcending the Talented Tenth: Black Leaders and American Intellectuals. NY: Routledge, 1997. Print.

Jameson, Fredric. "Periodizing the 60s." Social Text 9 (1984): 178-209. Print.

Johnson, Charles. “A Sangha by Another Name.” Tricycle. Tricycle, n.d. Web. 15 March 2011.

---. Dreamer: A Novel. New York: Scribner, 1998. Print.

---. "Ethics and Literature." Ethics, Literature, Theory: An Introductory Reader. Stephen K. George, Ed. Lanham, MD: Roman and Littlefield, 2005. Print.

---. Turning the Wheel: Essays on Buddhism and Writing. New York: Scribner, 2003. Print.

Joyce, Joyce A. "'Who the Cap Fit': Unconsciousness and Unconscionableness in the Criticism of Houston A. Baker, Jr., and Henry Louis Gates, Jr.” New Literary History 18.2 (1987): 371-384. Print. 
Kleinberg, Jay S. The Practice of US Women's History: Intersections, Narratives, and Dialogues. Piscataway, NJ: Rutgers UP, 2007. Print.

Knight, Peter. The Kennedy Assassination. Jackson: University of Mississippi Press, 2007. Print. LaCapra, Dominick. History in Transit: Experience, Identity, Critical Theory. Ithaca: Cornell UP, 2004. Print.

Landsberg, Alison. Prosthetic Memory: The Transformation of American Remembrance in the Age of Mass Culture. New York: Columbia UP, 2004. Print.

Lazerow, Jama and Yohuru R. Williams, eds. In Search of the Black Panther Party: New Perspectives on a Revolutionary Moment. Durham, NC: Duke UP, 2006. Print.

Lentricchia, Frank, Ed. Introducing Don DeLillo. Durham: Duke UP, 1991. Print.

Levine, George. "Risking the Moment: Anarchy and Possibility in Pynchon's Fiction." Mindful Pleasures: Essays on Thomas Pynchon. Eds. George Levine and David Leverenz. Boston: Little, Brown, and Company, 1976. Print.

Little, Jonathan. "Buddhism is the Most Radical and Civilized Choice." By John Malkin. Shambhala Sun. January 2004. Web. 10 February 2011.

Lorde, Audrey. Sister Outsider: Essays and Speeches. Freedom, CA: The Crossing Press, 1984. Print.

Lowenthal, David. The Past is a Foreign Country. New York: Cambridge UP, 1985. Print. Lundeen, Kathleen. "Who Has the Right to Feel? The Ethics of Literary Empathy." Mapping the Ethical Turn: A Reader in Ethics, Culture, and Literary Theory. Ed. Todd F. Davis. Charlottesville, VA: University Press of Virginia, 2001. Print.

Lyotard, Jean-Francois. The Inhuman: Reflections on Time. Stanford: Stanford UP, 1988. Print. 
Lytle, Mark Hamilton. America's Uncivil Wars: The Sixties Era from Elvis to the Fall of Richard Nixon. New York: Oxford UP, 2006. Print.

Mailer, Norman. Advertisements for Myself. 1959. Cambridge, MA: Harvard UP, 1992. Print.

---. An American Dream. New York: Dial Press, 1965. Print.

---. “Only in America.” The New York Review of Books. 2003. Web. 23 August 2011.

--- The Armies of the Night: History As a Novel, the Novel As History. New York: Signet, 1968. Print.

Malkin, John. "Buddhism is the Most Radical and Civilized Choice.” Shambhala Sun. January 2004. Web. 10 February 2011.

Marlantes, Karl. What It Is Like to Go to War. NY: Atlantic Monthly Press, 2011. Print. Marx, Leo. The Machine in the Garden: Technology and the Pastoral Ideal in America. 1964. New York: Oxford UP, 2000. Print.

McClintock, Anne. "“No Longer in a Future Heaven': Gender, Race, and Nationalism.” Dangerous Liaisons: Gender, Nation, and Postcolonial Perspectives. Ed. Anne McClintock, et. al. Minneapolis: University of Minnesota Press, 1997. 89-113. Print.

McHale, Brian. Postmodernist Fiction. New York: Methuen, 1987. Print.

McMahon, Jennifer and Steve Csaki, eds. The Philosophy of the Western. Lexington: University of Kentucky Press, 2010. Print.

Michael, Magali Cornier. Feminism and the Postmodern Impulse: Post-WWII Fiction. Albany: State University of New York Press, 1996. Print.

Millet, Kate. Sexual Politics. 1970. Champaign, IN: University of Indiana Press, 2000. Print. Mills, Charles. The Racial Contract. Ithaca: Cornell UP, 1997. 
Mohanty, Satya. Literary Theory and the Claims of History: Postmodernism, Objectivity, Multicultural Politics. Ithaca: Cornell UP, 1997. Print.

Morgan, Edward P. "The Good, the Bad, and the Forgotten: Media Culture and Public Memory of the Civil Rights Movement." The Civil Rights Movement in American Memory. Eds. Leigh Raiford and Renee C. Romano. Athens: University of Georgia Press, 2006. Print.

---. The Sixties Experience: Hard Lessons About Modern America. Philadelphia: Temple UP, 1992. Print.

Morrison, Toni. Playing in the Dark: Whiteness and the Literary Imagination. New York: Vintage, 1992. Print.

---. "Rootedness: The Ancestor as Foundation.” Ed. Mari Evans. Black Women Writers: Arguments and Interviews. London: Pluto Press, 1985. Print.

Mutua, Athena D. Progressive Black Masculinities. New York: Routledge, 2006. Print.

Nadel, Alan. Containment Culture: American Narratives, Postmodernism, and the Atomic Age. Durham, NC: Duke UP, 1995. Print.

Nash, Gary. "The Application of an Ideal: Turning the Wheel as Ontological Program.” Charles Johnson: The Novelist as Philosopher. Eds. Marc C. Conner and William R. Nash. Jackson: The University of Mississippi Press, 2007. Print.

Nash, William R. "The Application of an Ideal: Turning the Wheel as Ontological Program.” Charles Johnson: The Novelist as Philosopher. Eds. Marc C. Conner and William R. Nash. Jackson: The University Press of Mississippi, 2007. Print.

Nealon, Jeffrey. Post-Postmodernism: Or, the Cultural Logic of Just-in-Time Capitalism. Stanford: Stanford UP, 2012. Print.

Nussbaum, Martha C. Love's Knowledge: Essays on Philosophy and Literature. New York: 
Oxford UP, 1990. Print.

Olsen, Tillie. “I Stand Here Ironing.” Tell Me a Riddle: Collections. Philadelphia: Lippincott, 1961. Print.

Parker, David. Ethics, Theory, and the Novel. Cambridge and NY: Cambridge UP, 1995. Print.

Passaro, Vince. "Dangerous Don DeLillo.” Conversations with Don DeLillo. DePietro, Thomas, Ed. Jackson: University of Mississippi Press, 2005. Print.

Pease, Donald. The New American Exceptionalism. Minneapolis: University of Minnesota Press, 2009. Print.

Peniel, Joseph E. Dark Days, Bright Nights: from Black Power to Barack Obama. NY: Basic Civitas, 2010. Print.

Perkins, Margo V. Autobiography as Activism: Three Black Women of the Sixties. Jackson: University Press of Mississippi, 2000. Print.

Pickett, Brent. On the Use and Abuse of Foucault for Politics. Lanham, MD: Lexington, 2005.

Pizer, Donald. Twentieth-Century American Literary Naturalism: An Interpretation. Carbondale, IL: Southern Illinois University Press, 1982. Print.

Pollock, Della, ed. Remembering: Oral History Performance. New York: Palgrave Macmillan, 2005. Print.

Posner, Richard. “Against Ethical Criticism.” Ethics, Literature, Theory: An Introductory Reader. Stephen K. George, Ed. Lanham, MD: Roman and Littlefield, 2005. Print.

Preece, Rob. The Psychology of Buddhist Tantra. Ithaca, NY: Snow Lion, 2006. Print. Print.

Prins, Gwen. “Oral History.” New Perspectives on Historical Writing. Ed. Peter Burke. University Park, PA: University of Pennsylvania, 1992. Print. 
Pynchon, Thomas. “A Journey Into the Mind of Watts.” The New York Times on the Web. 1966. Web. 25 August 2011.

---. V. New York: J.B. Lippincott, 1963. Print.

---.Vineland. Boston: Little, Brown, 1990. Print.

Rambsy, Kenton. “Occupy Wall Street and Ralph Ellison: African American Novels and Organized Resistance." HBW: The Project on the History of Black Writing. 8 Nov. 2011. Web. 29 Feb. 2012.

Riley, Patricia. “Wrapped in the Serpent's Tail: Alice Walker's African-Native American Subjectivity." When Brer Rabbit Meets Coyote: African-Native American Literature. Ed. Jonathan Brennan. Champaign: University of Illinois Press, 2003. Print.

Robnett, Belinda. How Long? How Long?: African-American Women in the Struggle for Civil Rights. New York: Oxford UP, 1997. Print.

Rogin, Michael. Ronald Reagan, the Movie, and Other Episodes in Political Demonology. Berkley and Los Angeles: The University of California Press, 1987. Print.

Rorty, Richard. Contingency, Irony, and Solidarity. New York: Cambridge UP, 1989.

Roth, Michael. The Ironist's Cage: Memory, Trauma, and the Construction of History. New York: Cambridge UP, 1995. Print.

Sales Jr., William. From Civil Rights to Black Liberation: Malcolm X and the Organization of Afro-American Unity. Boston: South End Press, 1994.

Samantrai, Ranu. AlterNatives: Black Feminism in the Postimperial Nation. Stanford: Stanford UP, 2002. Print.

Sauer, Michael. “'I Want to Write Like a Good Jazz Musician': Interview with Toni Morrison.” Carolyn C. Denard, ed. Toni Morrison: Conversations. Jackson: University of 
Mississippi Press, 2008. Print.

Schreier, Benjamin. The Power of Negative Thinking: Cynicism and the History of Modern American Literature. Charlottesville, VA: University of Virginia Press, 2009. Print.

Schultz, Bud and Ruth Schultz. The Price of Dissent: Testimonies to Political Repression in America. Berkely: University of California Press, 2001. Print.

Schultz, Debra L. Going South: Jewish Women in the Civil Rights Movement. New York: NYU Press, 2001. Print.

Scott, Peter Dale. The Road to 9/11: Wealth, Empire, and the Future of America. Berkley: University of California Press, 2008. Print.

Skerl, Jennie. Reconstructing the Beats. New York: Macmillan, 2004. Print.

Smethurst, Paul. The Postmodern Chronotope: Reading Space and Time in Contemporary Fiction. Amsterdam; Atlanta, GA: Rodopi, 2000. Print.

Smith, Barbara Herrnstein. Contingencies of Value: Alternative Perspectives for Critical Theory Boston: Harvard UP, 1988. Print.

Smith, Barbara, ed. Home Girls: A Black Feminist Anthology. New Brunswick, NJ: Kitchen Table: Women of Color Press, 1983. Print.

Smith, Felipe. “Alice Walker's Redemptive Art.” Critical Essays on Alice Walker. Ed. Ikenna Dieke. Westport, CT: Greenwood, 1999. Print.

Smith, Carlton. Coyote Kills John Wayne: Postmodernism and Contemporary Fictions of the Transcultural Frontier. Hanover, NH: University Press of New England, 2000. Print. Smith, Gregory. Nietzsche, Heidegger, and the Transition to Postmodernity. Chicago: University of Chicago Press, 1996. Print

Stafford, Jean. A Mother in History. New York: Farrar, Straus and Giroux, 1966. Print. 
Stone, Robert. Prime Green: Remembering the Sixties. New York: Harper Collins, 2007. Print. Storhoff, Gary. “The Artist as Universal Mind: Berkeley’s Influence on Charles Johnson.” African American Review 30.4 (1996). Print.

---. Understanding Charles Johnson. Columbia: University of South Carolina Press, 2004. Print.

Suiter, John. Poets on the Peaks: Gary Snyder, Philip Whalen, and Jack Kerouac in the North Cascades. Berkley, CA: Counterpoint Press, 2002. Print.

Tabbi, Joseph. Postmodern Sublime: Technology and American Writing from Mailer to Cyberpunk. Ithaca: Cornell UP, 1995. Print.

“The Federal Reserve’s ‘Breathtaking’ \$7.7 Trillion Bank Bailout.” The Week. 28 Nov. 2011. Web. 29 Feb 2012.

Thomas, Samuel. Pynchon and the Political. New York: Routledge, 2007.

Thoreen, David. “The Fourth Amendment and Other Modern Inconveniences: Undeclared War, Organized Labor, and the Abrogation of Civil Rights in Vineland." Thomas Pynchon: Reading from the Margins. Ed. Niran Abbas. Cranbury, NJ: Rosemont, 2003. Print.

Tucker, Lindsey. "Walking the Red Road: Mobility, Maternity, and American Myth in Alice Walker's Meridian.” Women's Studies 19 (1991): 1-17. Print.

Vansina, Jan. Oral Tradition as History. Madison, WI: University of Wisconsin Press, 1985. Print.

Vonnegut, Kurt. Slaughterhouse-Five, Or, the Children's Crusade: A Duty-Dance with Death. New York: Random House, 1969. Print.

Wald, Priscilla. Constituting Americans: Cultural Anxiety and Narrative Form. Durham: Duke UP, 2005. Print. 
Walker, Alice. Anything We Love Can Be Saved: A Writer's Activism. New York: Random House, 1997. Print.

---. In Search of Our Mothers' Gardens: Womanist Prose. New York: Harcourt Brace Jovanovich, 1983. Print.

---. Meridian. New York: Harcourt Brace Jovanovich, 1976. Print.

---. We Are the Ones We Have Been Waiting for: Inner Light in a Time of Darkness. New York: Norton, 2006. Print.

Walker, Melissa. Down From the Mountaintop: Black Women's Novels in the Wake of the Civil Rights Movement, 1966-1989. New Haven: Yale University Press, 1991. Print.

West, Cornel. The Ethical Dimensions of Marxist Thought. New York: Monthly Review Press, 1991. Print.

Whalen-Bridge, John. "Waking Cain: The Poetics of Integration in Charles Johnson's Dreamer." Callaloo 26.2 (2003): 504-21. Print.

Will, George. One Man's America: The Pleasures and Provocations of Our Singular Nation. New York: Random House, 2008.

---. "Shallow Look At the Mind of An Assassin." The Washington Post. 22 Sept. 1988. Web. 10 Nov. 2010.

---. The Woven Figure: Conservatism and America's Fabric. New York: Scribner, 1997.

Wilson, Sharon. “A Conversation With Alice Walker.” Alice Walker: Critical Perspectives Past and Present. Eds. Henry Louis Gates and Kwame Anthony Appiah. New York: Amistad, 1993. Print.

Wright, Richard. 12 Million Black Voices. 1941. New York: Thunder's Mouth Press, 2002. Print. Writers for the 99\%. Occupying Wall Street: The Inside Story of an Action that Changed 
America. NY: OR Books, 2011. Print.

X, Malcolm and Benjamin Karim, ed. The End of White World Supremacy: Four Speeches. New York: Merlin House, 1971. Print.

Yardley, Jonathan. “Appointment in Dallas.” The Washington Post. 31 July 1988. Web. 11 Nov. 2010.

---. “Don DeLillo's American Nightmare.” The Washington Post. 13 Jan. 1985. Web. 11 Nov. 2010.

Yee, Shirley J. Black Women Abolitionists: A Study in Activism, 1828-1860. Knoxville: University of Tennessee Press, 1992. Print.

Yuval-Davis, Nira. Gender and Nation. London: Sage Publications, 1997. Print 


\section{Jason M. Stupp}

4 Chapel St.

Cuba, NY 14727

315-224-6944

jstupp@mix.wvu.edu

\section{Education}

\section{Ph.D in English Literature}

West Virginia University

Dissertation: "The Word and the World: The Activist Spirit in American Literature, 1968-1998"

Director: Dr. Katy Ryan

\section{MA in English Literature}

St. Bonaventure University

BA in Journalism/Mass Communications

St. Bonaventure University

St. Bonaventure, NY

\section{Teaching/Research Interests}

Twentieth-Century American Literature; Literary Postmodernism; African American Studies;

Composition; Critical Pedagogy; Performance Studies

\section{Awards and Honors}

\section{West Virginia University:}

English Department Dissertation Fellowship 2011

English Department Summer Research Grant 2010

The Eberly College of Arts and Sciences Outstanding Graduate Teaching Assistant in 2009 English (College award)

The WVU English Department Outstanding Graduate Teaching Assistant 2009 (Department award)

Ginsberg Fund Award for Doctoral Travel 2009

Ginsberg Fund Award for Doctoral Travel 2008

Graduate Teaching Assistantship w/ Full Tuition Remission 2006

\section{St. Bonaventure University:}

The Outstanding Academic Achievement Award for Excellence in the Graduate English Curriculum

Graduate scholarship (50\% tuition remission) 
Teaching Fellowship

2005

Learning Fellowship

2004

\section{Teaching Experience}

West Virginia University (Graduate Teaching Assistant)

$2006-12$

English 241: American Literature I

English 242: American Literature II (focus on working-class literature)

English 132: Short Story and Novel

English 131: Poetry and Drama (focus on twentieth-century African American Lit)

English 102: Research and Argumentation (portfolio, 8 sections)

English 101: Composition and Rhetoric, Fine Arts Emphasis (portfolio)

English 101: Composition and Rhetoric (portfolio, 3 sections)

Fairmont State University/Pierpont Community and Technical College (Adjunct Instructor)

English 1109: Technical and Professional Writing

2008-11

English 1104: Written English I (9 sections, focus on creative writing)

English 0097: Composition Skills (6 sections)

St. Bonaventure University (Graduate Teaching Assistant)

2004-06

Clare 111: Composition and Critical Thinking II (3 sections)

Clare 110: Composition and Critical Thinking I (2 sections)

Clare 111: Composition and Critical Thinking II (TA)

Clare 110: Composition and Critical Thinking I (TA)

\section{Publications}

"Living Death: Ernest Gaines's A Lesson Before Dying and the Execution of Willie Francis." Demands of the Dead: Executions, Storytelling, and Activism in the United States. Ed. Katy

Ryan. Iowa City: University of Iowa Press, 2012.

"Slavery and the Theatre of History: Ritual Performance on the Auction Block." Theatre Journal 63 (2011): 61-84.

"Demystifying Prison Life for Greater Reflection." Teaching Seeing and Writing 4. Ed. Kim Haimes-Korn, et al. Boston: Bedford/St. Martin’s, 2010.

\section{Conference Presentations}

"Working Class American Literature: Reading from the 'Bottom Up." The Modern Language Association (MLA) Annual Conference, Seattle, WA, 2012. 
"Composition and Incarceration: Redefining 'Community' in the Writing Classroom." The Northeast Modern Language Association (NEMLA) Annual Conference, New Brunswick, NJ, 2011.

"Slavery and the Theatre of History: Ritual Performance and Disembodiment on the Auction Block.” The Mid-America Theatre Conference (MATC), Cleveland, OH, 2010.

"Condemned Communities: The U.S. Carceral State and Radical Black Autobiography." The Modern Language Association (MLA) Annual Conference, Philadelphia, PA, 2009.

"The Jack Bauer Response: George W. Bush's Post-9/11 Speeches and the Reaction of White America." The New York College English Association (NYCEA) Annual Conference, St. Bonaventure University, 2008.

"Tearing Down the Veil: The Search for an Articulate Voice in Richard Wright's Native Son.”The American Literature Association Conference (ALA), Boston, 2007.

"Fragment of a Vessel: Examining the Global Legacy of Colonialism in Wole Soyinka's Death and the King's Horseman." The African Literature Association Conference, West Virginia University, 2007.

\section{Memberships}

Modern Language Association

Mid-America Theatre Conference

Northeast Modern Language Association

\section{Service}

Referee, College Literature

2010-Present

Presenter, Professional Development Workshop on Civic Engagement 2010

Vice President, Appalachian Prison Book Project (WVU)

2007-Present

Graduate Mentor for WVU English Department GTAs (WVU)

References (Common Address: WVU English Department, 100 Colson Hall, 1503 University Ave, PO Box 6296, Morgantown, WV 26506)

Dr. Katy Ryan, Assistant Professor of English

304.293.9729, kohearnr@wvu.edu.

Dr. John Ernest, Eberly Family Distinguished Professor of American Literature

304.293.9714, john.ernest@mail.wvu.edu

Dr. Dennis Allen, Professor of English

304.293.9702, dallen@wvu.edu

Dr. Nathalie Singh-Corcoran, Clinical Assistant Professor/Writing Center Coordinator 304.293.9731, nathalie.singh-corcoran@mail.wvu.edu 